\title{
A Nearly Complete Juvenile Skull of the Marsupial Sparassocynus derivatus from the Pliocene of Argentina, the Affinities of "Sparassocynids", and the Diversification of Opossums (Marsupialia; Didelphimorphia; Didelphidae)
}

\author{
Robin M. D. Beck ${ }^{1,2,3}$ (I) Matias L. Taglioretti ${ }^{4,5}$ \\ Published online: 23 July 2019 \\ (C) The Author(s) 2019
}

\begin{abstract}
"Sparassocynids" are small, carnivorously-adapted marsupials known from the late Miocene and Pliocene of South America, thought to be relatives of living didelphid opossums but of otherwise uncertain phylogenetic relationships. Here, we describe a nearly complete juvenile skull of the "sparassocynid" Sparassocynus derivatus, from the Pliocene $(\sim 5-3$ million years old $)$ Chapadmalal Formation, Argentina. It provides new information on the morphology of Sparassocynus, including the deciduous dentition, and (together with previously collected specimens) allows reinterpretation of the derived auditory region of "sparassocynids." The new specimen also exhibits several distinctive apomorphies characteristic of Didelphidae and of subclades within the family. Undated Bayesian phylogenetic analysis of a total evidence dataset (132 craniodental characters, $7.3 \mathrm{~kb}$ of DNA sequence data from five nuclear genes) places "sparassocynids" within the didelphid genus Monodelphis, whereas "tip-and-node" dating analysis of the same dataset with an Independent Gamma Rates (IGR) clock model places them as sister to Monodelphis, showing that temporal information influenced the resultant topology. We conclude that "sparassocynids" warrant tribal separation only, as Sparassocynini, new rank. Based on our dated phylogeny, we also provide a revised scenario for didelphid diversification. Crown-clade didelphids probably originated close to the Oligocene-Miocene boundary. We agree with previous proposals that the appearance of carnivorously-adapted didelphids in South America during the late Miocene, including sparassocynins, is likely related to a decline in diversity of the sparassodonts at this time, and that the disappearance of these carnivorously-adapted didelphids at the end of the Pliocene may have been due to the arrival of placental carnivorans, such as mustelids, from North America.
\end{abstract}

Electronic supplementary material The online version of this article (https://doi.org/10.1007/s10914-019-09471-y) contains supplementary material, which is available to authorized users.

Robin M. D. Beck

r.m.d.beck@salford.ac.uk

1 School of Environmental and Life Sciences, University of Salford, Manchester, UK

2 School of Biological, Earth and Environmental Sciences, University of New South Wales, Sydney, New South Wales, Australia

3 Department of Mammalogy, American Museum of Natural History, New York, NY, USA

4 Laboratorio de Paleontología, Museo Municipal de Ciencias Naturales 'Lorenzo Scaglia', Plaza España, Mar del Plata, Buenos Aires, Argentina

5 Grupo de Geología Costera y Paleoecología, Instituto de Geología de Costas y Cuaternario, Universidad Nacional de Mar del Plata - CIC, Buenos Aires, Argentina
Keywords Sparassocynus · Didelphidae - Opossums · Tip-dating $\cdot$ Pliocene $\cdot$ Chapadmalal formation

$\begin{array}{ll}\text { Abbreviations } & \\ \text { AMNH M- } & \begin{array}{l}\text { Mammalogy collection of the } \\ \text { American Museum of Natural History, } \\ \text { New York, USA } \\ \text { Colección de la Facultad de Ciencias } \\ \text { Exactas y Naturales, Universidad Nacional } \\ \text { de La Pampa, Santa Rosa, Argentina } \\ \text { Geological Museum of INGEOMINAS, } \\ \text { BGM }\end{array} \quad \begin{array}{l}\text { Bugotá, Colombia } \\ \text { "Buseo Argentino de Ciencias Naturales }\end{array} \\ \text { MACN } & \begin{array}{l}\text { Argentina } \\ \text { Museo de La Plata, La Plata, Argentina }\end{array}\end{array}$


MMP $\quad$ Museo Municipal de Ciencias

Naturales "Lorenzo Scaglia,"

Mar del Plata, Argentina

\section{Introduction}

The genus Sparassocynus Mercerat, 1898, comprises three described species of small ( 300-400 g; Zimicz 2014), carnivorously-adapted metatherians known from the latest Miocene to Pliocene of Argentina (Abello et al. 2015): S. bahiai Mercerat, 1898, from the Montehermosan ( 5.2-5.0 MYA) South American Land Mammal Age (SALMA); S. derivatus Reig and Simpson, 1972, from the Chapadmalalan $(\sim 5.0-3.0$ MYA) SALMA and the Vorohuean ( 2.9-2.7 MYA; Prevosti and Forasiepi 2018) subage of the Marplatan SALMA; and S. maimarai Abello et al., 2015, the only known specimen of which is 5.9-5.06 Ma old (Abello et al. 2015). A fourth species, "Sparassocynus" heterotopicus Villarroel and Marshall, 1983, from the Montehermosan of Bolivia, is of questionable taxonomic status (Forasiepi et al. 2009; Abello et al. 2015).

Sparassocynus is currently placed within the family "Sparassocynidae," which also includes the older and somewhat more plesiomorphic Hesperocynus dolgopolae (Reig 1958a) from the Huayquerian SALMA ( 8.7-5.2 MYA; Deschamps et al. 2013) of Argentina (Forasiepi et al. 2009, 2011). "Thylatheridium" hudsoni and other, currently unnamed specimens from the Huayquerian Cerro Azul Formation of Argentina may also represent "sparassocynids" (Goin et al. 2000; Forasiepi et al. 2009). An as-yet undescribed partial cranium from the La Venta Fauna (type locality of the Laventan SALMA, 13.5-11.8 MYA; Madden et al. 1997) in Colombia (see Goin 1997a: 194-195) has been argued to exhibit features that are likely ancestral for this group (Goin 1995). In addition, Goin (1995: 170) briefly mentioned "sparassocynid" material from Chasicoan-aged ( $\sim 10$ 8.7 MYA; Zarate et al. 2007) deposits of the Pampean Region, but this likewise does not appear to have been described.

In terms of higher-level relationships, "sparassocynids" have been consistently identified as "didelphimorphians" (Forasiepi et al. 2009; Abello et al. 2015). However, "Didelphimorphia" sensu lato is a wastebasket taxon (Forasiepi et al. 2009; Beck in press): in addition to the $>120$ species of living didelphid opossums (which collectively comprise the didelphimorphian crownclade), a diverse range of dentally plesimorphic metatherians from the Mesozoic and Cenozoic of the northern and southern hemispheres, including both crown- and stem-marsupials, have been referred to this group at one time or another (see Beck in press for a recent review). Nevertheless, given their known morphology and their temporal and biogeographical range, it seems highly likely that sparassocynids are members of Didelphimorphia sensu stricto (= Didelphoidea sensu Goin
1991, 1995), i.e., more closely related to didelphids than to any other extant marsupial group.

Reig et al. (1987) presented a series of phylogenies focused on "didelphimorphians," some of them including Sparassocynus, based on parsimony analysis of morphological (primarily dental) characters. These phylogenies consistently supported a close relationship between Sparassocynus, the extant didelphid Lutreolina, and the fossil didelphids Hyperdidelphys and Thylophorops, all of which exhibit derived dental features indicative of carnivory. These taxa were joined by members of Sparassodonta (another clade of carnivorously-adapted metatherians from South America) when the latter were added to the analysis. However, more recent phylogenetic analyses based on much larger morphological datasets indicate that sparassodonts are stem-marsupials that are only very distantly related to didelphids (e.g., Forasiepi 2009; Engelman and Croft 2014; Forasiepi et al. 2014). It is likely that the grouping of these taxa in Reig et al.'s (1987) analyses was largely driven by the shared presence of a carnivorously-adapted ("carnassialized") dentition, which is known to be highly homoplastic within mammals (Muizon and Lange-Badré 1997), as Reig et al. (1987: 80) themselves concluded. Thus, the results of these analyses do not clearly resolve the affinities of "sparassocynids."

More recently, detailed studies of the anatomy and phylogeny of the didelphimorphian crown-clade (= Didelphidae sensu Voss and Jansa 2009) have led to the identification of numerous phylogenetically informative morphological characters (Voss and Jansa 2003, 2009; Flores 2009). These include at least one highly distinctive cranial feature that is likely a synapomorphy of Didelphidae: fusion between the interparietal and supraoccipital early in postnatal life (Nesslinger 1956; Clark and Smith 1993; Voss and Jansa 2009). Several other character states optimize as synapomorphies of various didelphid subclades (Voss and Jansa 2003, 2009; Flores 2009). Until now, presence or absence of many of these features could not be confidently determined in "sparassocynids" based on available specimens; particularly problematic has been the absence of well-preserved juvenile material. Nevertheless, several authors (Beck et al. 2012; Engelman and Croft 2014) have already raised the possibility that "sparassocynids" may in fact belong within Didelphidae.

Here, we describe a new, nearly complete skull of a juvenile of Sparassocynus derivatus collected from the Chapadmalal Formation (Chapadmalalan SALMA) at its type locality in Mar del Plata, Buenos Aires Province, Argentina (Figs. 1 and 2; Ameghino 1908; Kraglievich 1952; Zárate and Fasano 1989; Cione et al. 2007; Isla et al. 2015). The specimen clarifies the anatomy of this taxon and preserves previously unknown features, including the deciduous dentition. Together with other Sparassocynus specimens, it confirms that this taxon exhibits a number of distinctive apomorphies, particularly in the auditory region, and it also reveals that certain features have been misinterpreted in previous studies (Reig and Simpson 1972; Simpson 1972, 1974). However, other features strongly suggest 


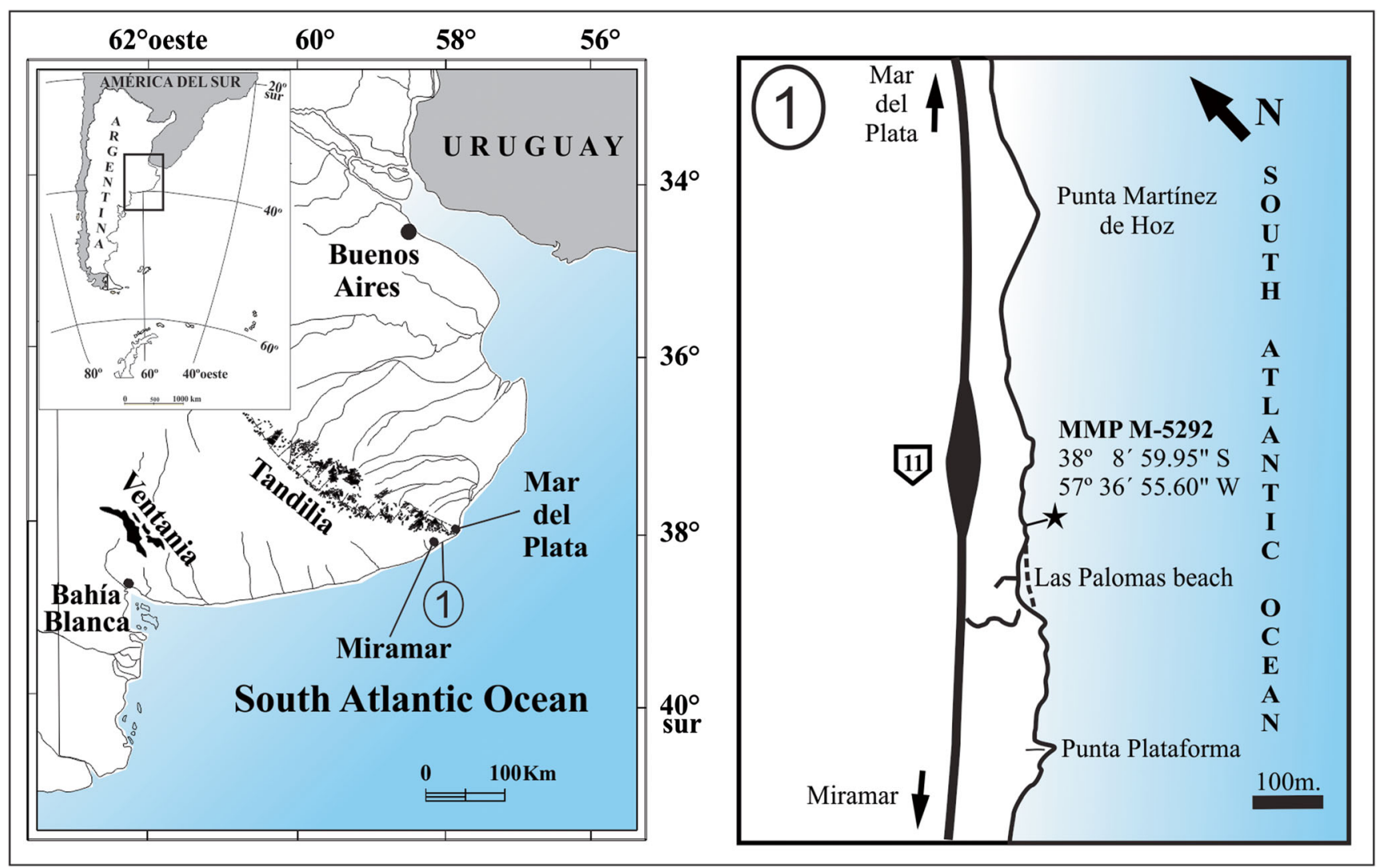

Fig. 1 Map showing area surrounding Mar del Plata (left), and locality where specimen MMP-M-5292 was collected (right)

that Sparassocynus (and also Hesperocynus) is a member of Didelphimorphia sensu stricto, and that it probably falls within Didelphidae.

We formally tested this hypothesis by adding Sparassocynus derivatus and Hesperocynus dolgopolae to a modified version of the total evidence matrix of Voss and Jansa (2009). We used Bayesian undated and tip-and-node dating approaches (Ronquist et al. 2012a; O'Reilly and Donoghue 2016; Zhang et al. 2016) to analyze this dataset, which confirm that Sparassocynus and Hesperocynus are didelphids, and so should not be assigned their own family. However, the two different analyses show intriguing topological differences regarding the exact position of Sparassocynus and Hesperocynus within Didelphidae, demonstrating that the inclusion of temporal information can have a major impact on phylogenetic analyses. We use the phylogeny that resulted from our tip-and-node dating analysis to present a revised timescale and scenario for the diversification of Didelphimorphia.

\section{Materials and Methods}

\section{Systematics}

We follow Beck et al.'s (2014) crown-based definition for Marsupialia, namely the least inclusive clade containing
Didelphis marsupialis, Caenolestes fuliginosus, and Phalanger orientalis. Didelphimorphia sensu stricto (= Didelphoidea sensu Goin 1991, 1995) is currently recognized as comprising didelphids plus all taxa more closely related to didelphids than to other marsupials, but currently lacks a formal phylogenetic definition. We therefore propose a stembased definition for Didelphimorphia here (see "Systematic Paleontology" below).

We follow Voss and Jansa (2009) in recognizing crown-clade didelphimorphians as comprising only a single family, Didelphidae. Likewise, we follow Voss and Jansa (2009) in recognizing four subfamilies within Didelphidae: Glironiinae, Caluromyinae, Hyladelphinae, and Didelphinae. Within Didelphinae, Voss and Jansa (2009) recognised four tribes: Marmosini, Metachirini, Didelphini, and Thylamyini. Our phylogenetic analyses place Sparassocynus and Hesperocynus within Marmosini sensu Voss and Jansa (2009; see "Results"); however, and bearing in mind that taxonomic ranks are biologically arbitrary, the numerous autapomorphies of Sparassocynus and Hesperocynus would seem to warrant their distinction at the tribal level at least, as Sparassocynini. To ensure a monophyletic tribal classification within Didelphidae, this requires that Marmosini be restricted to the Marmosa lineage, with the Monodelphis lineage, and probably also the Tlacuatzin lineage (depending on its precise relationship to the Marmosa lineage), raised to tribal rank, as Monodelphini and Tlacuatzinini, respectively. Our usage of 
Fig. 2 Plio-Pleistocene stratigraphic profile for Mar del Plata region showing levels where Sparassocynus specimens discussed in this work were collected. Chronostratigraphic Stage/Age scheme follows Cione et al. (2015)

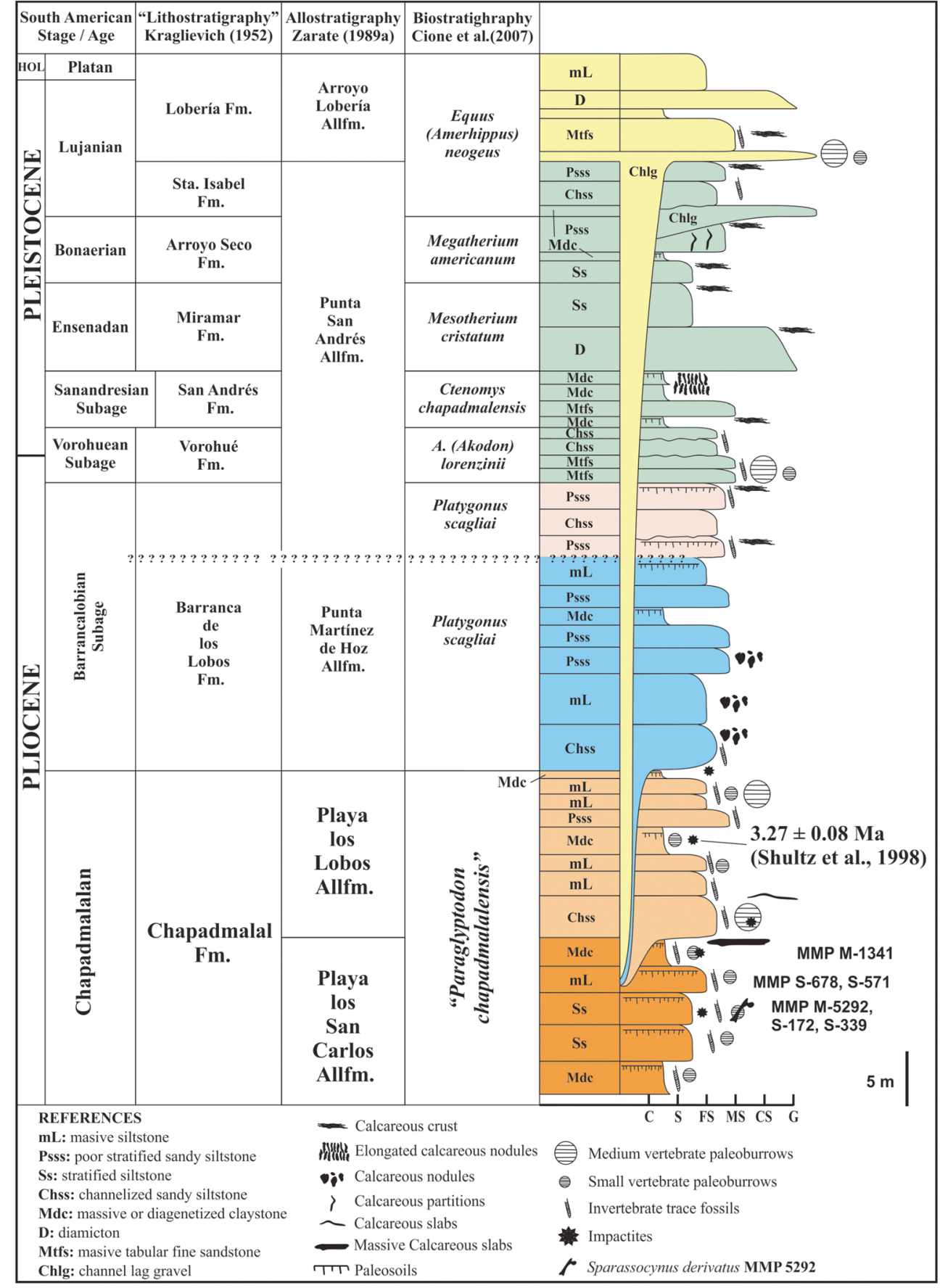

Monodelphini is similar to that of Goin $(1991,1995)$ who used this name to refer to Monodelphis and its fossil relative Thylatheridium (see Reig 1958a; Goin 1991, 1995; Goin and Rey 1997; Voss and Jansa 2009). Some other classifications have used Monodelphini in a very different, much more inclusive sense, to refer to "murine" opossums (e.g., McKenna and Bell 1997; Gardner 2008), but this assemblage has been found to be non-monophyletic in all recent phylogenetic studies of didelphids (e.g., Voss and Jansa 2009; Jansa et al. 2014; Díaz-Nieto et al. 2016).

\section{Anatomical Terminology}

Terminology for dental anatomy follows Reig et al. (1987: fig. 1), Goin and Candela (2004: fig. 2), Voss and Jansa (2009), and Williamson et al. (2014: fig. 3). Terminology for cranial anatomy largely follows Voss and Jansa (2009) and Wible (2003); we note where these references differ (for example, regarding the identities of the subsquamosal and suprameatal foramina). 
One piece of terminology relating to the auditory region warrants additional comment. Sparassocynus shares with most dasyuromorphians (the fossil Badjcinus is the sole known exception; Muirhead and Wroe 1998), some peramelemorphians, and the didelphid Caluromysiops, the presence of a prominent cavity (which is at least partially enclosed laterally) within the squamosal, posterolateral to the epitympanic recess (see "Description"). van der Klaauw (1931: 82) referred to this cavity in dasyuromorphians and peramelemorphians as an "epitympanic sinus," which has been followed by most subsequent authors (e.g., Archer 1976a; Marshall 1977a; Aplin 1990; Wroe 1997, 1999) and is the term we use here. In dasyuromorphians and peramelemorphians (and almost certainly also Caluromysiops and Sparassocynus), in life this depression is (or was) enclosed by the pars flaccida (or "membrana shrapnelli") of the tympanic membrane, and so lies within the cavum tympani (the limits of which are defined by the membrana epitympanica dorsally, the fibrous membrane ventrally, and the tympanic membrane medially; SánchezVillagra and Forasiepi 2017: 23), which is housed by the definitive tympanic cavity. Thus, it meets van der Klaauw's (1931: 73) definition of epitympanic sinuses, namely "accessory cavities of the tympanic cavity lying in the squamosal or in the mastoid, which contain no essential parts of the tympanic cavity and which start from the recessus epitympanicus." By contrast, Wible (1990: 200) referred to this cavity as a "suprameatal fossa," following Segall's (1943) use of the term to refer to a depression he observed in the squamosal of procyonid carnivorans that receives the pars flaccida (see also Hunt 1991: 9; Lopatin 2003: 659, figs. 2, and 4).

\section{Specimens Examined}

The main focus of this work is MMP M-5292, an almost complete cranium and left and right dentaries (plus articulated vertebrae still within the matrix) of a late-stage juvenile (age class 4 of Tyndale-Biscoe and MacKenzie (1976) and Tribe (1990); age class G3a of van Nievelt and Smith 2005) of Sparassocynus derivatus. This specimen was collected in 2012 from the Chapadmalal Formation near Mar del Plata, Buenos Aires Province, Argentina (Figs. 1 and 2), by one of us (MLT), F. Isla, and F. Scaglia. Its identification as $S$. derivatus is based on the presence of a distinct posterolingual cuspule (= "protocone" sensu Reig and Simpson 1972) on P1 and P2 (Fig. 3a). We also examined the following adult cranial specimens of $S$. derivatus, all of which have been collected from the lower levels of the Chapadmalal Formation (Fig. 2): MMP S-172 (holotype), S-339, S-S-571, S-678 and $\mathrm{M}-1341$.

\section{Phylogenetic Analysis}

To formally test the phylogenetic affinities of Sparassocynus and Hesperocynus, we used a modified version of the total evidence matrix of Voss and Jansa (2009). We deleted the four karyotype characters, and added three additional cranial characters to reflect striking features of the auditory region of Sparassocynus and Hesperocynus (Electronic Supplementary Material, Text S1 and Data S1). This resulted in a total of 128 morphological characters, of which 39 are from (soft) external morphology, 52 (including the three new characters) are from the cranium and mandible, and 37 are from the dentition. Of these, 16 represent plausible morphoclines, and so were specified as ordered, as in Voss and Jansa's (2009) original study. The molecular data from Voss and Jansa (2009) comprises 7320 bp of aligned DNA sequence data from five nuclear protein-coding genes, namely $B R C A 1, D M P 1$, $R B P 3$ (= "IRBP"), RAG1, and VWF. The RAG1 sequence data comprises the first two codon positions only; Voss and Jansa (2009) removed the third codon position due to the presence of extreme variation in GC content among didelphids, which has been shown to mislead phylogenetic analyses of the group (Gruber et al. 2007).

Sparassocynus derivatus and Hesperocynus dolgopolae were scored for the revised morphological matrix, with scorings for $S$. derivatus based on the MMP specimens, and those for $H$. dolgopolae based on the descriptions of Simpson (1974) and Forasiepi et al. (2009). We modified three character scorings for Caluromysiops irrupta to better match our observations (Electronic Supplementary Material, Text S1 and Data S1). We also scored our three new cranial characters for Voss and Jansa's (2009) original set of taxa. The molecular matrix was left largely unchanged from Voss and Jansa (2009), except that we added a partial BRCAl sequence (KU171173) for Chacodelphys formosa (see Díaz-Nieto et al. 2016), and we replaced the original $R B P 3$ sequence for Sminthopsis crassicaudata (FJ159327, which does not appear to pertain to this taxon) with a more recent sequence (KJ129985) from Giarla and Jansa (2014). The final combined total evidence matrix comprised the 44 extant didelphids and seven extant non-didelphid marsupial outgroup taxa originally included by Voss and Jansa (2009), plus the two fossil taxa added here, resulting in a total of 53 taxa (Electronic Supplementary Material, Data S1).

To identify an appropriate partitioning scheme and set of substitution models for the molecular matrix, we used PartitionFinder2.1.1 (Lanfear et al. 2017), using the Bayesian Information Criterion (BIC) for model selection, and employing the "greedy" search algorithm. We only tested those models implemented by MrBayes, and we did not test for models that combine a gamma distribution for among-site rate heterogeneity with a proportion of invariant sites, following the recommendations of Stamatakis (2016). The molecular matrix was initially partitioned by gene and codon position (a total of 
14 partitions, given that the 3 rd codon position of $R A G 1$ was excluded), with PartitionFinder recommending combining these into six partitions (Electronic Supplementary Material, Table S1).

We analyzed the combined total evidence matrix using MrBayes 3.2.6 (Ronquist et al. 2012b), using both undated and "tip-and-node dating" approaches (O'Reilly and Donoghue 2016). For the undated analysis, the morphological partition was assigned the Mk substitution model (Lewis 2001). In the first iteration of this morphological dataset, Voss and Jansa (2003: 8) made a deliberate attempt to include autapomorphies, and in the version used here, 15 of the 128 characters (i.e., $\sim 12 \%$ ) are autapomorphic; thus we used the $\mathrm{M} k \mathrm{v}$ model, which assumes that all variable characters are included (i.e., autapomorphies are taken into account when estimating branch lengths). Inclusion of autapomorphies may be particularly important for tip-dating analyses, if the data have evolved in a clocklike manner (Matzke and Irmis 2018). It should also be noted that the model used by MrBayes to correct for the inclusion of parsimony-informative characters only, $\mathrm{M} k_{\text {parsinf }}$, is probably only correctly implemented for binary characters at present (Matzke and Irmis 2018). Amongcharacter rate heterogeneity was modelled using a lognormal distribution with eight rate categories (Harrison and Larsson 2015), while the molecular partition was assigned the sixpartition scheme and set of substitution models identified by PartitionFinder2.1.1 (Electronic Supplementary Material, Table S1). The analysis comprised four independent runs of four chains each (three "heated," one "cold"), with the temperature of the heated chains reduced to 0.05 . The analysis was run for $20 \times 10^{6}$ generations, using a parsimony starting tree, and sampling trees every 5000 generations. Stationarity and convergence was identified using Tracer v1.6 (Rambaut et al. 2014), and post-burn-in trees were summarized using $50 \%$ majority-rule consensus, giving Bayesian posterior probabilities (BPPs) as nodal support values.

For the tip-and-node dating, we assigned all 51 extant taxa an age of 0 Ma. Codings for Sparassocynus derivatus were based on specimens from the Chapadmalal Formation, and so this taxon was assigned an age range of 5.0-3.3 MYA (= Chapadmalalan SALMA) based on the proposed maximum age for this formation (5.0 MYA; Woodburne 2010), and because the specimens are below geological evidence of an impact event that has been dated as 3.3 MYA (Fig. 2; Schultz et al. 1998). Codings for Hesperocynus dolgopolae were based on written descriptions and figures of specimens from the Andalhualá and La Huertita formations of Argentina (Simpson 1974; Forasiepi et al. 2009). The precise age of the La Huertita Formation is unclear (it may be Pliocene; Garrido et al. 2014), but radiometric dates suggest an age range of 7.14-5.22 MYA (i.e., within the Huayquerian SALMA) for the Andalhualá Formation (Deschamps et al. 2013), and this has been used as the assumed age range for
Hesperocynus dolgopolae here. Tip-dating alone, without the use of nodal calibrations, often results in implausibly ancient divergences (Beck and Lee 2014; O'Reilly et al. 2015; O'Reilly and Donoghue 2016); thus, we also specified six internal node calibrations (Australidelphia, Agreodontia, Dasyuridae, Peramelidae, Didelphidae, and Didelphis + Philander), plus a calibration on the age of the root, based on current fossil evidence (Electronic Supplementary Material, Text S2). MrBayes requires that calibrated nodes be constrained a priori, but we note that all six calibrated nodes received strong support $(\mathrm{BPP} \geq 0.99)$ in the undated analysis. The root calibration and three of the internal node calibrations were specified as uniform distributions with "hard" minimum and maximum ages, reflecting the limited fossil evidence constraining the maximum age of these nodes; the remaining three internal node calibrations used exponential distributions with "hard" minimum ages but "soft" maximum ages that allowed a 5\% probability older divergence estimates (Ho and Phillips 2009) (Electronic Supplementary Material, Text S2). We specified a fossilized birth-death tree branching prior, assuming "diversity" sampling, which requires an estimate of how many extant taxa are sampled (Zhang et al. 2016). There are $\sim 120$ currently recognized extant didelphid species, of which 44 (i.e., $~ 37 \%$ ) are included here; we set the sampling probability as 0.3 (i.e., $30 \%$ ), to take into account the likely identification of some additional extant species in future.

We used stepping stone analysis (Xie et al. 2011; Ronquist et al. 2012b) to estimate the marginal likelihoods of four different clock model schemes: a single Independent Gamma Rates (IGR) model for the entire total evidence matrix (Lepage et al. 2007); a single Thorne and Kishino 2002 (TK02) model (Thorne and Kishino 2002); separate IGR models for the molecular and morphological partitions; and separate TK02 models for the molecular and morphological partitions. Bayes factors (Kass and Raftery 1995; Nylander et al. 2004) suggested that the best-fitting clock model scheme was separate molecular and morphological IGR models (Electronic Supplementary Material, Text S3). We then ran our tip-and-node dating analysis using this best-fitting clock model scheme, the other priors discussed above, and the same substitution models and MrBayes search parameters used in the undated analysis. Tracer was again used to identify stationarity and convergence between chains, and the post-burnin trees were concatenated using the perl script Burntrees.pl (available from https://github.com/nylander/Burntrees), with branch lengths transformed from substitutions per site to time units. These were then summarized into a Maximum Clade Credibility (MCC) tree using TreeAnnotator v1.8.3, with node ages calculated as median heights, and support values given as BPPs.

All data generated or analyzed during this study are included in this published article (and its supplementary information files). 


\section{Systematic Paleontology}

MARSUPIALIA (ILLIGER, 1811) sensu Beck et al. 2014

DIDELPHIMORPHIA GILL, 1872, new definition

Definition We propose a stem-based phylogenetic definition of Didelphimorphia, namely the most inclusive clade containing Didelphis marsupialis, but not Caenolestes fuliginosus or Phalanger orientalis.

\section{DIDELPHIDAE GRAY, 1821}

\section{SPARASSOCYNINI REIG, 1958b, new rank}

Revised Diagnosis Sparassocynins differ from other known didelphids in the following combination of probable apomorphic features (most of which can currently only be assessed in Sparassocynus): i1-2 without a distinct lingual cusp or heel (also seen in didelphins); molar dentition strongly carnassialized, with postmetacrista longer, paracone and protocone smaller, protoconid taller, and talonid narrower (with the $\mathrm{m} 3$ hypoconid lingually placed relative to the protoconid) than in most other known didelphids; rostrum proportionally shorter and posterior braincase proportionally wider than in other known didelphids; premaxillary rostral process sensu Voss and Jansa $(2003,2009)$ absent; maxillopalatine fenestrae present but small (not extending anteriorly beyond the midpoint of $\mathrm{m} 1$ or posteriorly beyond the posterior margin of $\mathrm{m} 2$ ) and well separated mediolaterally; posterior palatal margin (postpalatal torus) with distinct "corners" (as in all known didelphids except Caluromys, Caluromysiops, and Glironia); lacrimal with a distinct tubercle (the orbital margin of the lacrimal is smoothly rounded in all other known didelphids); maxilla and alisphenoid in contact in the ventral floor of the orbit (also seen in Lutreolina, Monodelphis, and Thylatheridium); midfrontal suture fused in subadults (also seen in Chironectes, Didelphis, Lutreolina, and Philander); postorbital processes well developed, becoming enormous and hornlike (larger than in any other known didelphids) in adult specimens; prominent squamosal epitympanic sinus present lateral to the epitympanic recess (also seen in Caluromysiops); hypotympanic sinus enormously expanded both ventrally and dorsally, lateral to endocranial cavity; alisphenoid tympanic process very large, forming ventrally expanded hemisphere, with posterior margin separated from the rostral tympanic process of the petrosal by a narrow gap; after exiting the endocranial cavity, the mandibular division of trigeminal nerve is enclosed in a bony canal in the medial wall of the hypotympanic sinus; transverse canal foramen and foramen ovale open within shared depression; rostral tympanic process of the petrosal extends the length of the promontorium, forming a triangular lamina the apex of which points laterally; rostral and caudal tympanic processes in contact but unfused; ectotympanic is a mediolaterally very broad half-cylinder, with a thickened lateral edge.

\section{SPARASSOCYNUS MERCERAT, 1898}

\section{SPARASSOCYNUS DERIVATUS REIG and SIMPSON, 1972}

Locality and Horizon MMP M-5292 (the focus of this paper) is from Playa Las Palomas, near Mar del Plata, Buenos Aires Province, Argentina (Fig. 1). The specimen was collected from a paleoburrow deposit in the lower part of paleosol P3 of the "Aloformación Playa San Carlos" (APSC) of the Chapadmalal Formation (Fig. 2; Isla et al. 2015). The age of the Chapadmalal Formation is approximately 5-3 MYA (= Chapadmalalan SALMA; Schultz et al. 1998; Woodburne 2010), with the APSC comprising the oldest levels (Fig. 2; Isla et al. 2015). The other $S$. derivatus specimens examined here are also from the Chapadmalal Formation (Fig. 2). Locality information for MMP S-172 (the holotype), MMP S-S-339, S-571 and S-678 is given in Reig and Simpson (1972). MMP M-1341 is from the Playa La Estafeta locality, "alocapa 5" of the "Aloformación Playa Los Lobos" (APLL). A Plio-Pleistocene stratigraphic profile for Mar del Plata region, including the Chapadmalal Formation and indicating the levels where these $S$. derivatus specimens were collected, is shown in Fig. 2.

Identity MMP M-5292 is clearly not Sparassocynus maimarai, due to its very small entoconids, and the lack of a lingual cingulid extending between the paraconid and metaconid on m1-3 (Fig. 3b; Abello et al. 2015). The P1 and $\mathrm{P} 2$ both have a posterolingual cuspule (Fig. 3a), suggesting that it represents $S$. derivatus, rather than S. bahiai (see Reig and Simpson 1972).

\section{Description}

Upper Dentition Both premaxillae are missing in MMP M-5292, and hence no upper incisors are preserved (Figs. 4, 5, 6 and 7). On the left side, the following upper teeth are present in situ: C1 P1-2 dP3 M1-3 (Figs. 5, 6, and 8). On the right side, the crown of $\mathrm{C} 1$ has broken off (but is still present with the specimen), but P1-2 dP3 M1-4 are all present in situ (Figs. 3a, 6, and 8). Of these, dP3 and M1-2 are moderately worn, $\mathrm{P} 1-2$ and $\mathrm{M} 3$ are lightly worn, and M4 is essentially unworn. M3 is fully erupted, but M4 is only partially erupted, and $\mathrm{P} 3$ has yet to erupt, indicating that it is the last tooth to emerge. Based on its stage of dental eruption, MMP M-5292 corresponds to age class 4 of Tyndale-Biscoe and MacKenzie (1976) and Tribe (1990), who examined a range 


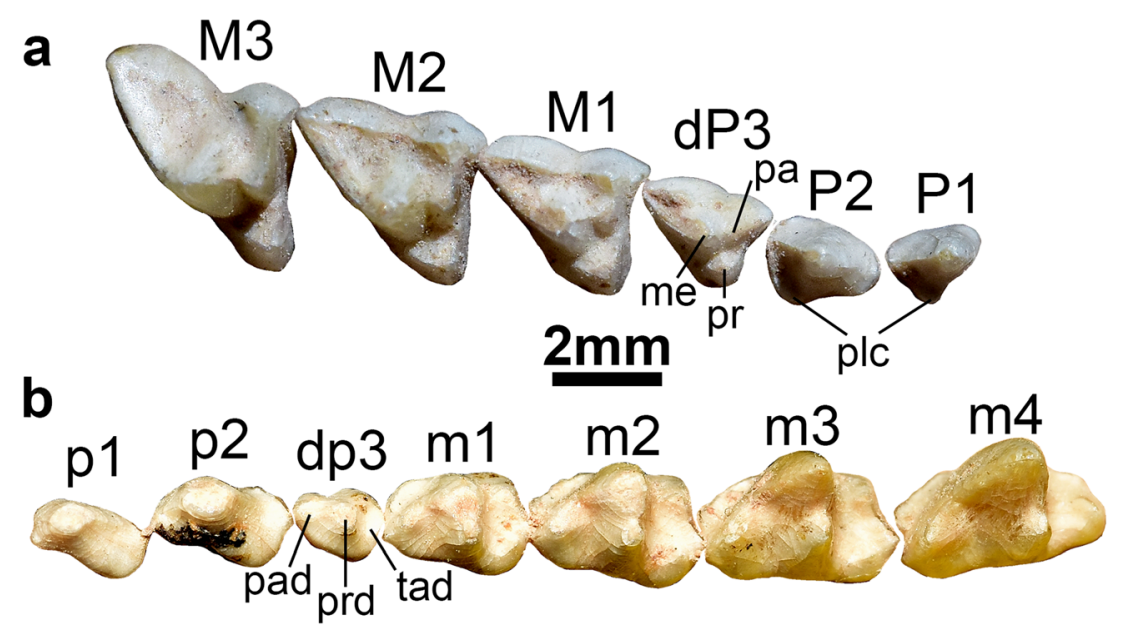

Fig. 3 Postcanine dentition of MMP M-5292 (Sparassocynus derivatus) in occlusal view. a right upper postcanine dentition (P1-M3; M4 is incompletely erupted and is not shown here); $\mathbf{b}$ right lower postcanine dentition (p1-m4). Abbreviations: dP3, deciduous third upper premolar; $\mathrm{dp} 3$, deciduous third lower premolar; M1, first upper molar; m1, first

of extant didelphids, and age class G3a of van Nievelt and Smith (2005), who considered Monodelphis domestica only. Our observations regarding the upper dentition are largely in accord with the description of Reig and Simpson (1972), and so we give only a relatively abbreviated description here, focusing on the features identified by Voss and Jansa (2003, 2009) as useful for resolving didelphid taxonomy and phylogeny.

The $\mathrm{C} 1$ is simple and caniniform, without accessory cusps (Fig. 5). Based on MMP M-5292 (see Figs. 5, 6, 7 and 8) and other MMP specimens, it is unclear whether or not the $\mathrm{C} 1$ alveolus is within the premaxilla-maxilla suture, or entirely within the maxilla. However, additional material held at MLP (which we did not examine) indicates that the alveolus is indeed within the suture (R. S. Voss, pers. comm.), as in all extant didelphids except caluromyines (Voss and Jansa 2009). Engelman and Croft (2014: 685) reported that the $\mathrm{C} 1$ alveolus is within the premaxilla-maxilla suture in "sparassocynids," but we suspect that this conclusion is based on Fig. 4 of Reig and Simpson (1972), which is a composite line drawing that includes a number of inaccuracies and omissions.

$\mathrm{P} 1$ and $\mathrm{P} 2$ are typical, double-rooted premolariform teeth (Figs. 3a, 5, 6, and 8); P2 lacks the prominent cingula seen in caluromyine didelphids (Voss and Jansa 2009). However, P1 and $\mathrm{P} 2$ both have a small but distinct posterolingual cuspule (Fig. 3a), which Reig and Simpson (1972) identified as characteristic of $S$. derivatus. The dP3 of MMP M-5292 is tribosphenic, resembling a small molar (Figs. 3a, 5, 6, and 8): a distinct protocone is present, and the paracone and metacone are very close together but identifiable as separate cusps, with the metacone by far the taller of the two. The postmetacrista is long and well developed. All cusps and crests on the dP3 show evidence of wear. P3 is unerupted in lower molar; M2, second upper molar; m2, second lower molar; M3, third upper molar; $\mathrm{m} 3$, third lower molar; $\mathrm{m} 4$, fourth lower molar; me, metacone; P1, first upper premolar; $\mathrm{p} 1$, first lower premolar; $\mathrm{P} 2$, second upper premolar; $\mathrm{p} 2$, second lower premolar; pa, paracone; pad, paraconid; plc, posterolingual cuspule; pr, protocone; prd, protoconid; tad, talonid

MMP M-5292, but other specimens (e.g., MMP M-1341 and $\mathrm{S}-339$ ) show that $\mathrm{P} 3$ is much taller than $\mathrm{P} 2$ when erupted (see Reig 1958b: fig. 10a), and that $\mathrm{P} 3$ has a prominent posterior cutting edge only, as in most dentally generalized marsupials, but unlike the didelphids Caluromys, Caluromysiops, Glironia, and Hyladelphys (see Voss and Jansa 2009).

On M1-2 (Fig. 3a), stylar cusp B is prominent and attached to the preparacrista, whereas stylar cusp A and stylar cusp D are much smaller but still identifiable. However, only stylar cusp B is distinct on M3. The postmetacrista is unnotched, and this crest is much longer on M3 (extending far labially due to an enlarged metastylar region) than on M1-2. The protocone is small on all molars. A very small paraconule appears to be present on M2-3, but a metaconule is consistently absent. The centrocrista is best described as weakly v-shaped. The preprotocrista does not form a continuous shelf with the anterolabial cingulum, but instead terminates slightly beyond the lingualmost part of the paracone. The postprotocrista terminates at the base of the metacone, and lacks the carnassial notch found in didelphin didelphids (Voss and Jansa 2009).

Lower Dentition The left mandible of MMP M-5292 preserves the roots of i1-3, and intact i4, c1, p1, dp3 and $\mathrm{m} 1-4$ (Figs. 12, 13 and 14). Only the roots of $\mathrm{p} 2$ are present in the mandible, but the crown of this tooth is preserved embedded in matrix that is attached to the cranium, lingual to P1 and P2 (Fig. 8). The right mandible preserves i1-4 c1 p1-2 dp3 m1-4 (Figs. $3 \mathrm{~b}, 12,13$ and 14). The $\mathrm{m} 4$ is fully erupted, in contrast to the only partially erupted M4. In terms of tooth wear, p1-2, dp3, and $\mathrm{m} 1-2$ are moderately worn, $\mathrm{m} 3$ is lightly worn, and $\mathrm{m} 4$ is essentially unworn. As with the upper dentition, we largely agree with the observations of Reig and Simpson (1972) regarding the lower dentition (also illustrated by Abello et al. 
2015: fig. 3a), and so do not describe it in detail here. Again, we focus on features discussed by Voss and Jansa (2003, 2009).

Of the four lower incisors, the second is clearly staggered. Matrix partially conceals i3-4 in MMP M-5292 (Fig. 14), but i1-2 clearly lack a distinct lingual cusp or heel; a lingual cusp or heel is present in most didelphids, but it is absent in didelphins and some other dentally plesiomorphic marsupials (e.g., the dasyurid Dasyurus, peramelemorphians; Voss and Jansa 2009). There is no posterior lobe on i3 or i4, whereas a lobe is present on the $\mathrm{i} 3$ of peramelemorphians and many dasyurids (Archer 1976b; Muirhead and Filan 1995; Voss and Jansa 2009).

The $\mathrm{c} 1$ is a simple, caniniform tooth, without accessory cusps or cingula (Figs. 13 and 14). The p1 and p2 are typical doublerooted premolariform teeth (Figs. 3b, 12, 13 and 14). The p3 is unerupted in MMP M-5292, but other specimens show that $\mathrm{p} 2$ and $\mathrm{p} 3$ are about the same height (see Reig 1958b: fig. 9) when fully erupted and unworn. The dp3 is more-or-less tribosphenic, with a recognizable trigonid and talonid, but is somewhat simplified (Figs. 3b, 12, 13 and 14): only two cusps can be identified on the trigonid (a large protoconid and a tiny paraconid at the anterior end of the paracristid), and distinct cusps cannot be recognized on the talonid.

In the lower molars, a hypoconulid notch is consistently present in the well-developed anterior cingulid, and a posterior cingulid is consistently absent (Figs. 3b, 12). The metaconid is basally confluent with the protoconid, but has a distinct apex dorsally. The protoconid is the tallest trigonid cuspid, followed by metaconid, with the paraconid the shortest of the three. The paracristid is notched. The entoconid is very small, lower than the hypoconid, but about the same height as the hypoconulid; a faint preentocristid can be identified in the unworn lower molars of MMP M-5292, extending along the lingual margin of the talonid. The hypoconulid is clearly twinned with the entoconid, but not immediately posterior to it. The talonid is about the same width as the trigonid on $\mathrm{m} 1$, whereas the trigonid is wider than the talonid (i.e., the hypoconid is lingual to the protoconid) on m2-4 (Figs. 3b, 12).

Cranium The cranium of MMP M-5292 is almost complete and very well preserved (Figs. 4, 5, 6, 7, 8, 10, and 11): total preserved length is $\sim 4.6 \mathrm{~cm}$, and maximum width is $\sim 3.5 \mathrm{~cm}$. Neither premaxilla is preserved in MMP M-5292; however, MMP S-172 clearly indicates that a premaxillary rostral process sensu Voss and Jansa $(2003,2009)$ is absent in S. derivatus (see Reig and Simpson 1972: plate VI and fig. 4). The nasals extend posteriorly to between the orbits, further posterior than the lacrimals, and their posterior borders form a distinct median apex (Figs. 4 and 7). The anterior parts of the nasals are not preserved in MMP M-5292, but MMP M-1341 shows that they end in a distinct apex, whereas an apex is absent in dasyuromorphians and sparassodonts (Muizon

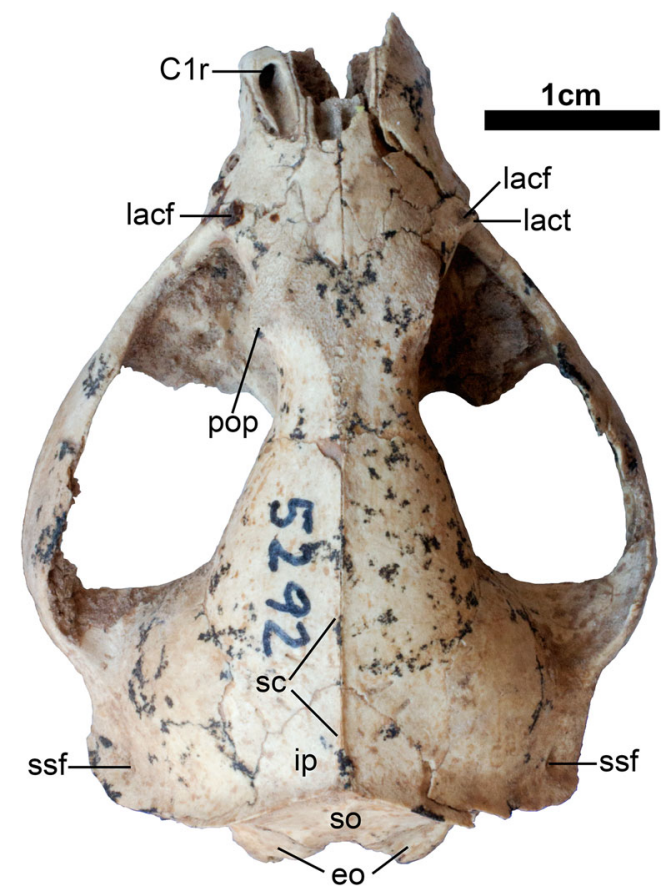

Fig. 4 Cranium of MMP M-5292 (Sparassocynus derivatus) in dorsal view. Abbreviations: $\mathrm{C} 1 \mathrm{r}$, exposed root of upper canine (broken); eo, exoccipital; ip, interparietal; lacf, lacrimal foramen; lact, lacrimal tubercle; pop, postorbital process; sc, sagittal crest; so, supraoccipital; ssf, subsquamosal foramen

1999: character 34; Forasiepi 2009: character 13; Voss and Jansa 2009). Posteriorly, the nasals expand laterally slightly, but they do not contact the lacrimals (Figs. 4 and 7); instead, the maxillae and frontals are in contact, as is typical for marsupials (Voss and Jansa 2009). By contrast, naso-lacrimal contact is typical for sparassodonts (Muizon 1999: character 29; Forasiepi 2009: character 16; Engelman and Croft 2014). The infraorbital foramen is large and opens above $\mathrm{dP} 3$ in MMP M5292 (Figs. 5, 6, and 7), and above P3 in adult specimens (Reig and Simpson 1972: fig. 1). An antorbital fenestra, a distinctive feature of some paucituberculatans (Goin et al. 2007b; Voss and Jansa 2009), is absent. Turbinals (which show considerable variation within marsupials; Voss and Jansa 2009; Macrini 2012) are not visible within the nasal cavity, but might be revealed by CT scanning.

Reig and Simpson (1972) concluded that S. derivatus has only a single lacrimal foramen (based on MMP S-172), but that S. bahiai has two (based on the holotype, MACN 2927). However, there are clearly two lacrimal foramina on the right side of MMP M-5292, which we identify as S. derivatus (Fig. 6); these two foramina are both entirely within the lacrimal, arranged dorsoventrally, and open on the facial exposure of the lacrimal, not within the orbit. They are separated by a bridge of bone that is surmounted by a lacrimal tubercle. Within the orbit, there are at least a further four much smaller (probably nutrient) foramina. On the left side, only one 


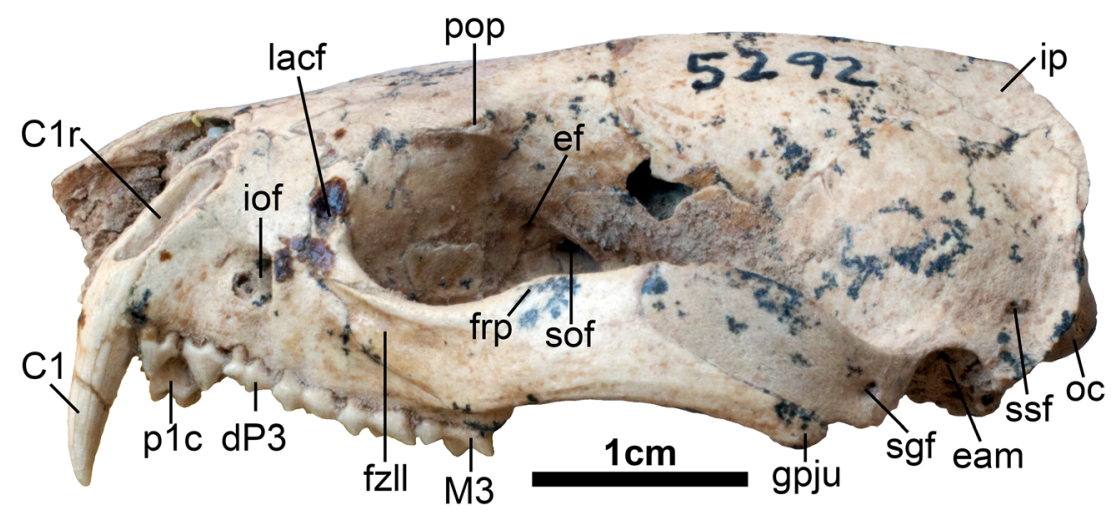

Fig. 5 Cranium of MMP M-5292 (Sparassocynus derivatus) in left lateral view. Abbreviations: C1, upper canine; C1r, exposed root of upper canine (broken); dP3, deciduous third upper premolar; eam, external acoustic meatus; ef, ethmoidal foramen; frp, frontal process of the jugal; fzll, fossa for zygomaticus and levator labii muscles; gpju, glenoid

opening can be identified on the facial exposure of the lacrimal, but this appears to be because the bony bridge present on the right side has broken away; no tubercle is identifiable (Figs. 5 and 7). There is another much smaller (again, presumably nutrient) foramen opening in the left lacrimal, immediately within the orbit. We suspect that that the apparently single foramen in MMP S-172 reported by Reig and Simpson (1972) is also the result of breakage.

Forasiepi et al. (2009: 1255) stated that the lacrimal tubercle is absent and the lacrimal foramen is "apparently single and relatively large" in the only known specimen of Hesperocynus dogolopae that preserves this region, MHNSR-PV 1046. We suspect that this morphology may also be artefactual (particularly given the reported large size of the lacrimal foramen), the result of damage similar to that observed on the right side of MMP M-5292 discussed above (Figs. 5 and 7). If so, Hesperocynus probably also has two lacrimal foramina, as in Sparassocynus and most extant process of the jugal; ip, interparietal; iof, infraorbital foramen; lacf, lacrimal foramen (?damaged); M3, third upper molar; oc, occipital condyle; p1c, broken crown of first lower premolar; pop, postorbital process; sgf, supraglenoid foramen; sof, sphenorbital fissure; ssf, subsquamosal foramen

didelphids (Chironectes and Hyladelphys are notable exceptions; Voss and Jansa 2009).

The medial wall of the orbit of MMP M-5292 and adult $S$. derivatus specimens show the typical arrangement of foramina seen in didelphids (Wible 2003; Voss and Jansa 2009): the sphenopalatine foramen is entirely within the palatine (Fig. 7), the ethmoid foramen is between the frontal and orbitosphenoid (Fig. 5), and the foramen rotundum is clearly separate from (and posterolateral to) the sphenorbital fissure (Fig. 9). The sphenorbital fissure opens through the cranium of MMP 5592 (Figs. 5 and 6), i.e., an interorbital fenestra is present, and a similar morphology can be seen in MMP S-571 (Fig. 9). The lacrimal contacts the palatine posteroventrally, and the lacrimal forms the dorsal border of the maxillary foramen (Fig. 7). An anterior process of the alisphenoid (similar to that described in Monodelphis by Wible 2003: 153, fig. 4; see also Voss and Jansa 2003, 2009) extends anterolaterally, lateral to the palatine, to contact the maxilla at a point level

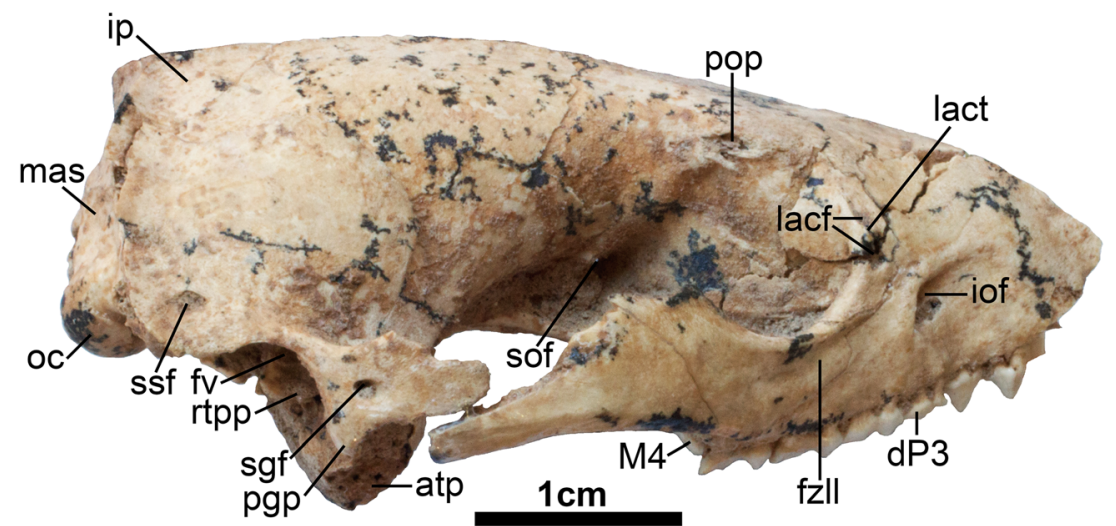

Fig. 6 Cranium of MMP M-5292 (Sparassocynus derivatus) in right lateral view. Abbreviations: atp, alisphenoid tympanic process; dP3, deciduous third upper premolar; fv, fenestra vestibuli; fzll, fossa for zygomaticus and levator labii muscles; iof, infraorbital foramen; ip, interparietal; lacf, paired lacrimal foramina; lact, lacrimal tubercle; M4, fourth upper molar; mas, mastoid; oc, occipital condyle; pgp, postglenoid process; pop, postorbital process; rtpp, rostral tympanic process of the petrosal; sgf, supraglenoid foramen; sof, sphenorbital fissure; ssf, subsquamosal foramen 


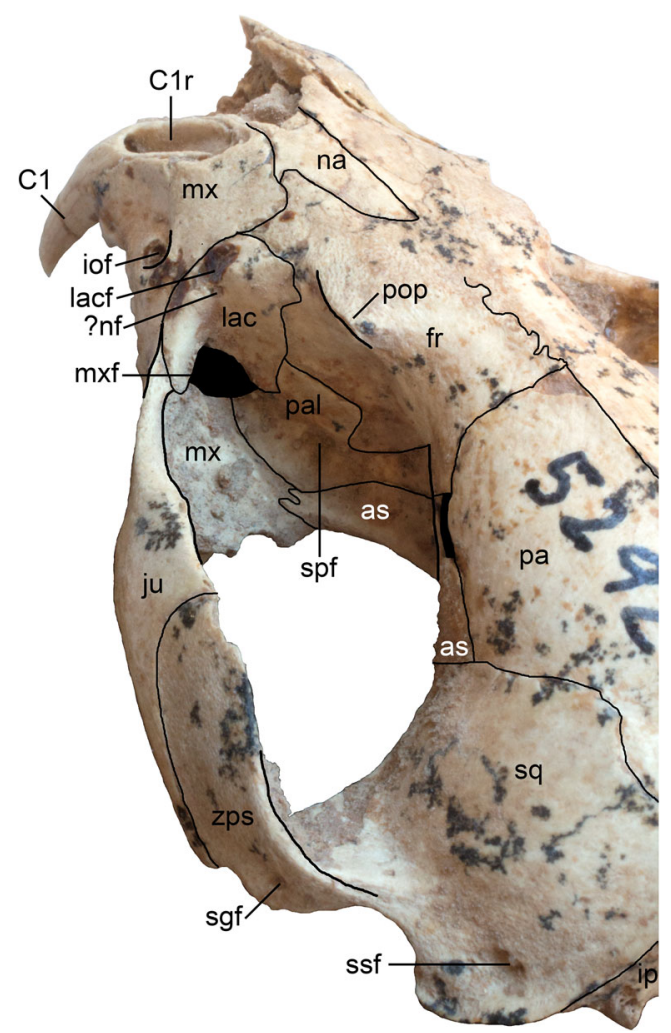

Fig. 7 Cranium of MMP M-5292 (Sparassocynus derivatus) in left oblique dorsolateral view. Sutures (thin black lines) and raised edges (thick black lines) are indicated on the left side of the cranium. Abbreviations: white; $\mathrm{C} 1$, upper canine; $\mathrm{C} 1 \mathrm{r}$, exposed root of upper canine (broken); fr, frontal; iof, infraorbital foramen; ip, interparietal; ju, jugal; lac, lacrimal; lacf, lacrimal foramen (?damaged); mx, maxilla; mxf, maxillary foramen; na, nasal;?nf,?nutrient foramen; pa, parietal; pal, palatine; pop, postorbital process; sgf, supraglenoid foramen; spf, sphenopalatine foramen; sq squamosal; ssf, subsquamosal foramen; zps, zygomatic process of the squamosal

with the sphenopalatine foramen (Fig. 7). Maxilla-alisphenoid contact within, or adjacent to, the orbital fossa is comparatively rare in metatherians. Among didelphimorphians, we have observed maxilla-alisphenoid contact only in Sparassocynus, Lutreolina, and Monodelphis (see Wible 2003; Voss and Jansa 2003, 2009), and it is also reportedly present in Thylatheridium (R. S. Voss, pers. comm.); we have otherwise seen it only in some diprotodontians (pers. obv.).

The maxilla-jugal suture is a simple crescent shape, with the jugal in contact with the lacrimal (Figs. 5 and 6). There is no raised masseteric process. There is a slight depression on the lateral face of the anterior part of the zygomatic arch (largely on the jugal) for the zygomaticus and levator labii muscles, but there is no deep nasolabial fossa. A weak frontal process is identifiable on the zygomatic process of the jugal (Fig. 5). The jugal ends posteriorly in a distinct preglenoid process (Figs. 5, 8, and 10). The glenoid fossa forms a single surface that curves posteroventrally onto the anterior face of the postglenoid process, which is well developed and mediolaterally broad (Figs. 6, 8, and 10). The postglenoid process is even more strongly developed in adult specimens, e.g., MMP S-339 (see Reig and Simpson 1972: fig. 3). A very well-developed glenoid process of the alisphenoid sensu Wible (2003 = "entoglenoid process of the alisphenoid" sensu Muizon 1998) is present. The postglenoid foramen is entirely within the squamosal, and it opens posterior to the medial edge of the postglenoid process (Fig. 10). The subsquamosal foramen sensu Voss and Jansa $(2009,=$ the "suprameatal foramen" sensu Wible 2003) opens posterodorsal to the external auditory meatus, and there is also a supraglenoid foramen opening above the postglenoid process (Figs. 5, 6, and 7 and $10)$.

A prominent cavity is present within the squamosal, lateral to the epitympanic recess, and is partially enclosed laterally (Figs. 8 and 10). We follow van der Klaauw (1931: 82) and most subsequent authors (e.g., Archer 1976a; Marshall 1977a; Aplin 1990; Wroe 1997, 1999; but see Wible 1990: 200) in referring to this cavity as a squamosal epitympanic sinus (see "Materials and Methods: Anatomical Terminology" above). Among didelphimorphians, we have observed a distinct squamosal epitympanic sinus lateral to the epitympanic recess only in Sparassocynus and Caluromysiops (see also Wible 1990: 200), although a weak depression is often present in this region in extant didelphids (Archer 1976a, 1982: 461). By contrast, a well-developed squamosal epitympanic sinus is a common (but not universal) feature of Australian marsupials (Archer 1976a; Wroe et al. 1998; Voss and Jansa 2009).

Postorbital processes are clearly identifiable in MMP M5292 (Figs. 4, 5, 6 and 7), but they are far less well developed than the very large, hornlike processes seen in adult specimens (e.g., MMP 339-S; Reig and Simpson 1972). As noted above, MMP M-5292 is a relatively late stage juvenile (age class 4 of Tyndale-Biscoe and MacKenzie 1976 and Tribe 1990; age class G3a of van Nievelt and Smith 2005). Adults of the extant didelphid Caluromys philander have very prominent postorbital processes (Voss and Jansa 2009: Fig. 38), and ontogenetic series (see Flores et al. 2010) reveal that these processes are already large in specimens in which $\mathrm{dP} 3$ is retained and M3 is only partially erupted (age class 3 of Tyndale-Biscoe and MacKenzie 1976 and Tribe, 1990; class G2 of van Nievelt and Smith 2005). Thus, the comparatively small size of the postorbital processes in a near subadult of Sparassocynus derivatus may be an indication that these processes increased markedly in size relative late in ontogeny compared to extant didelphids (see Voss and Jansa 2009: 31). Alternatively, it could be an indication of sexual dimorphism in S. derivatus, with MMP M-5292 representing a female, and specimens with very large postorbital processes (e.g., MMP S-339) representing males. However, distinguishing between these hypotheses will require testing via a suitably comprehensive morphometric study of available Sparassocynus specimens.

The midfrontal suture is identifiable in the posterior half of the frontals, but more anteriorly it appears to have fused (Figs. 4 
and 7). The midfrontal suture is consistently fused in the subadults and adults of the extant didelphids Chironectes Didelphis, Lutreolina, and Philander, and in older adults of Caluromysiops (see Voss and Jansa 2009). The midparietal suture, however, is unfused along its entire length in MMP M-5292. In adult specimens of Sparassocynus derivatus, the midparietal suture is normally concealed by the sagittal crest; however, MMP M-1341 includes a partial cranial roof, and in ventral view it can be seen that the midparietal suture remains unfused into adulthood in this taxon, as is typical for marsupials. A low sagittal crest is present in MMP M-5292, extending from the interparietal onto the parietals (following the midparietal suture), but it does not extend onto the frontals (Figs. 4 and 7). The sagittal crest is much more prominent in adult specimens (e.g., MMP M-1341, MMP S-339, MMP S-571), but likewise does not appear to extend anteriorly past the parietal-frontal suture. The alisphenoid and parietal are in contact, preventing squamosal-frontal contact. The petrosal is not exposed within the squamosal-parietal suture (Figs. 4, 5, 6, and 7). The interparietal appears fused to the supraoccipital, as in all extant didelphids (Voss and Jansa 2009): no suture is visible within or adjacent to the lambdoid crest. The lambdoid crest itself is relatively prominent in MMP M-5292, but it is much larger in adult specimens (Reig and Simpson 1972). The squamosals extend dorsally quite high up the lateral wall of the braincase, and they contact the interparietal (Figs. 4, 5, and 6).

The premaxillae are missing in MMP M-5292, but the posterolateral margins of the incisive foramina are identifiable, medial to the approximate midpoint of the $\mathrm{C} 1$ (Fig. 8); the dividing septum between them was presumably formed by the premaxillae. Previous studies have described Sparassocynus as entirely lacking palatal vacuities (Reig and Simpson 1972; Simpson 1972; Engelman and Croft 2014). However, short, slotlike openings are clearly present within the maxillopalatine suture of MMP M-5292 (Figs. 8 and 10). This opening is better preserved on the left side, where it extends from the approximate midpoint of $\mathrm{M} 1$ to the posterior margin of M2. These openings are more elongate than the simple foramina illustrated by Voss and Jansa (2009) for the extant didelphids Caluromys philander and Caluromysiops irrupta; they appear similarly positioned to, and only slightly smaller than, the maxillopalatine fenestrae of Monodelphis dimidiata (see Pine et al. 1985: fig. 4; Chemisquy 2015: fig. 1c). Similarly positioned, but proportionately slightly smaller, slotlike openings are also present in MMP S-339. Given that these openings in $S$. derivatus are anteroposteriorly elongate, and presumably are not purely vascular in function, they warrant description as true maxillopalatine fenestrae, rather than foramina. The condition in $S$. derivatus is very different from that seen in sparassodonts, in which the region of the palate adjacent to the maxillopalatine suture lacks fenestrae (although vascular foramina are present; Sinclair 1906; Marshall 1978; Engelman and Croft 2014: Fig. 4). MMP M-

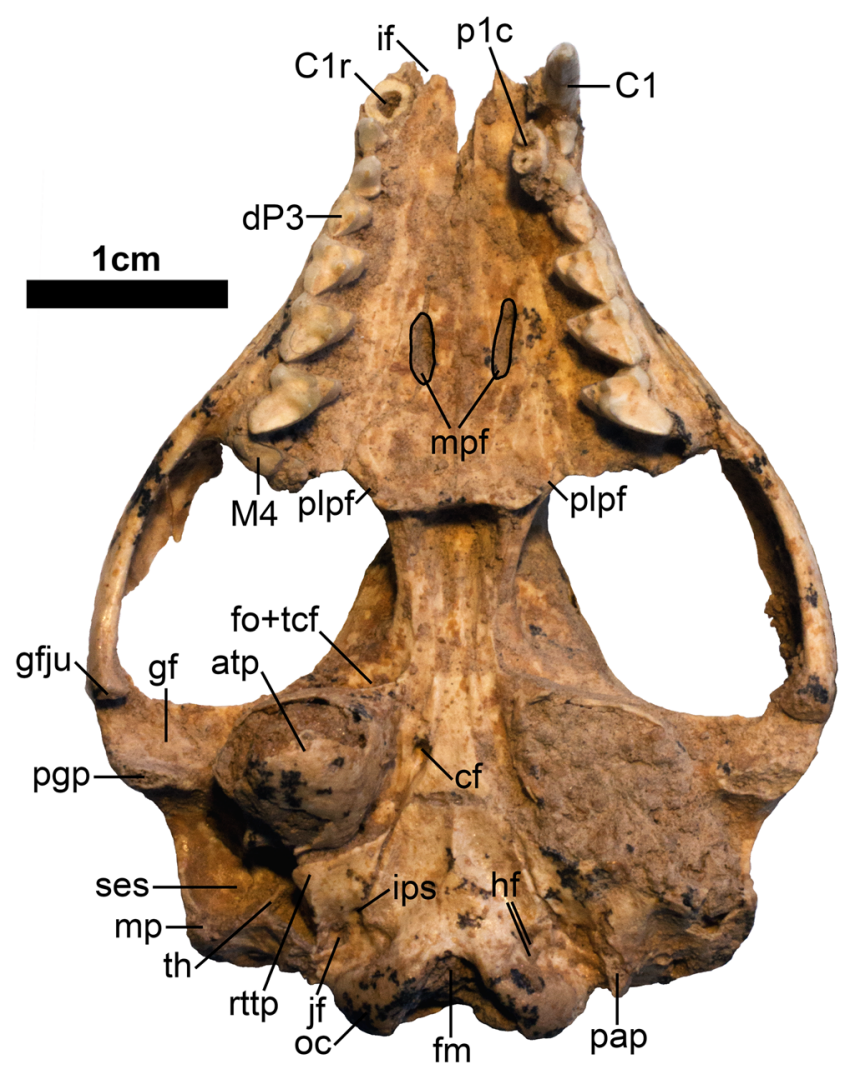

Fig. 8 Cranium of MMP M-5292 (Sparassocynus derivatus) in ventral view. Abbreviations: atp, alisphenoid tympanic process; $\mathrm{C} 1$, upper canine; $\mathrm{C} 1 \mathrm{r}$, exposed root of upper canine (broken); cf carotid foramen; $\mathrm{dP} 3$, deciduous third upper premolar; fm, foramen magnum; fo + tcf, common depression for the foramen ovale and transverse canal foramen; gf, glenoid fossa; gpju, glenoid process of the jugal; hf, hypoglossal foramina; if, incisive foramen (incomplete anteriorly); ips, foramen for the inferior petrosal sinus; jf, jugular foramen; M4, fourth upper molar; mp, mastoid process; mpf, maxillopalatine fenestrae; oc, occipital condyle; $1 \mathrm{c}$, broken crown of first lower premolar; pap, paroccipital process; pgp, postglenoid process of the exoccipital; plpf, posterolateral palatal foramen; rtpp, rostral tympanic process of the petrosal; ses, squamosal epitympanic sinus; th, tympanohyal

5292 and other $S$. derivatus specimens confirm, however, that maxillary fenestrae and palatine fenestrae (which occur in some extant didelphids; Voss and Jansa 2009) are absent in this taxon.

The posterolateral palatal foramen sensu Voss and Jansa $(2009,=$ the "minor palatine foramen" sensu Wible 2003) appears damaged in MMP M-5292 (Figs. 8 and 10) and also MMP S-339, and so we are uncertain whether or not it was complete or not based on these specimens. The posterolateral palatal foramen is usually complete in extant didelphids (although we have observed incomplete foramina in some specimens of Monodelphis brevicaudata, e.g., left side of AMNH M-257203, and left side of AMNH M-268060) and most other metatherians, but it is incomplete in most dasyurids (Wroe 1997; Voss and Jansa 2009). However, it is clear that the posterolateral palatal foramen did not extend anteriorly as far 
as the protocone of M4 in Sparassocynus derivatus. The posterior palatal margin (postpalatal torus) appears to have distinct "corners," resembling the (apparently apomorphic) condition seen in Hyladelphys and didelphine didelphids, but differing from the morphology seen in caluromyines and Glironia (Voss and Jansa 2003, 2009).

The vomer is not exposed in the roof of the nasopharyngeal passageway, posterior to the postpalatal torus, in either MMP M-5292 or MMP S-339. Although the region is damaged in MMP M-5292, MMP S-339, and MMP S-571, collectively these specimens are sufficient to reveal a "typical" didelphid arrangement of bones in the nasopharyngeal roof (Voss and Jansa 2009): specifically, the pterygoids do not meet in the midline, but they contact the presphenoid anteriorly, which prevents contact between the palatines and basisphenoid. MMP S-571 also shows that the pterygoids do not extend posteriorly as far as the carotid foramina.

The carotid foramen opens within the sphenoid complex, anterior to the basioccipital-basisphenoid suture (Fig. 8). A large transverse canal foramen is present anterolateral to the carotid foramen, opening within a depression that also houses the foramen ovale. It is unclear whether or not the transverse canal foramen has a complete dorsal roof within the endocranial cavity. A lamina of bone extends from the anteromedial border of the large alisphenoid tympanic process, and this forms a medial and ventral enclosure to the depression within which the transverse canal foramen and foramen ovale open. A similar morphology is seen in the adult specimens MMP S-571 (Fig. 9) and S-339; in the latter specimen, the surface of the bone adjacent to the foramen ovale is grooved, showing the path of the individual branches of the mandibular branch of the trigeminal nerve $\left(\mathrm{V}_{3}\right)$ after it divides: one branch passes laterally and slightly dorsally around

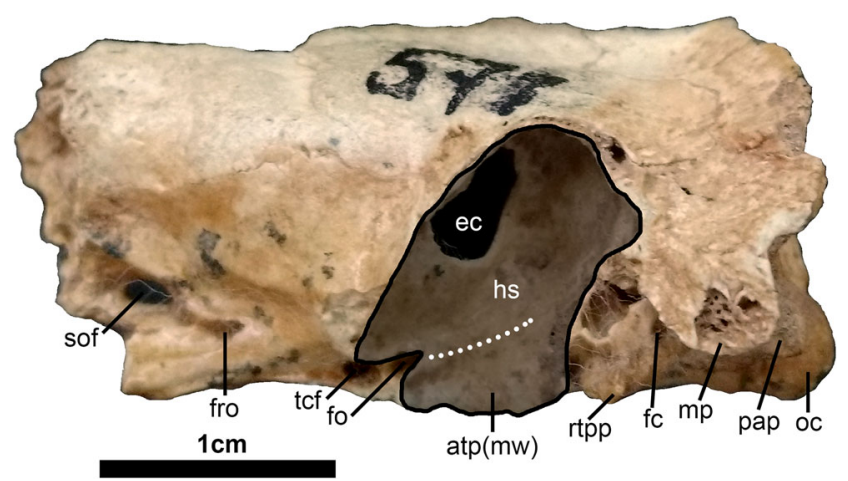

Fig. 9 Partial cranium of MMP S-571 (Sparassocynus derivatus) in left lateral view. Solid black line represents the broken edges of the hypotympanic sinus, dotted white line represents the path of the mandibular division of the trigeminal nerve (V3) within the medial wall of the alisphenoid tympanic process. Abbreviations: atp(mw), medial wall of the (broken) alisphenoid tympanic process; ec, endocranial cavity; fc, fenestra cochleae; fo, foramen ovale; fro, foramen rotundum; hs, hypotympanic sinus; mp, mastoid process; oc, occipital condyle; pap, paroccipital process of the exoccipital; rtpp, rostral tympanic process of the petrosal; sof, sphenorbital fissure; tcf, transverse canal foramen the anterior face of the base of alisphenoid tympanic process (and probably extends towards the glenoid fossa), and a second branch extends laterally and slightly ventrally. The transverse canal foramen and the foramen ovale also appear to be located in a common depression in Hesperocynus dolgopolae (see Forasiepi et al. 2009: fig. 3).

The right auditory region of MMP M-5292 is well preserved, with the alisphenoid tympanic process only slightly damaged (Figs. 6, 8, 10, and 11). The left auditory region is less complete: the entire alisphenoid tympanic process has broken away and the hypotympanic sinus is filled with matrix (Figs. 6, 8, 10, and 11). The alisphenoid tympanic process itself is enormous, forming a ventrally elongated hemisphere (Figs. 6, 8,7, 10, and 11; see also Reig and Simpson 1972: fig. $3)$. The degree of ventral expansion of the alisphenoid tympanic process (Fig. 11) is much greater than in any extant didelphid, and even appears greater than in dasyurids that have enlarged hypotympanic sinuses, such as Dasyuroides, Dasycercus, and Sarcophilus (see Jones 1949; Archer 1976a; Rose et al. 2017). In fact, among metatherians, the closest resemblance in terms of overall proportions is probably with the phascolarctid Phascolarctos cinereus (the extant koala), although the external surface of the tympanic process is smooth and rounded in Sparassocynus, whereas it is distinctly rugose in Phascolarctos (see Aplin 1987, 1990; Louys et al. 2009). In MMP M-5292, the posterior margin of the alisphenoid tympanic process closely approximates the rostral tympanic process of the petrosal, but does not quite contact it; there is a distinct gap between them (Figs. 8 and 10).

The broken cranium of MMP S-571 reveals that the mandibular division of the trigeminal nerve passes within a bony canal in the medial wall of the hypotympanic sinus, i.e., within the alisphenoid (Fig. 9). This morphology is somewhat reminiscent of that seen in Phascolarctos and other phascolarctids, although in phascolarctids the bony canal is in the dorsal roof (rather than the medial wall) of the hypotympanic sinus (Aplin 1987, 1990; Louys et al. 2009). The nerve then emerges via the foramen ovale, which opens at the anteromedial corner of the alisphenoid tympanic sinus, immediately posterior to the transverse canal foramen, with which it shares a common vestibule (see comments above). The morphology of the foramen ovale in $S$. derivatus is therefore unlike the condition in extant didelphids, in which the mandibular division of the trigeminal nerve is either unenclosed by bone after exiting the endocranial cavity, or is enclosed by a strut or medial lamina of the alisphenoid tympanic process that forms a secondary foramen ovale (Voss and Jansa 2003, 2009).

MMP S-571 reveals the internal structure of the hypotympanic sinus (Fig. 9): it is enormously inflated dorsally, extending lateral to the endocranial cavity to a point dorsal to the level of the squamosal-parietal suture visible on the external surface of the cranium. Reig and Simpson (1972) referred to the dorsal part of this space in Sparassocynus as 


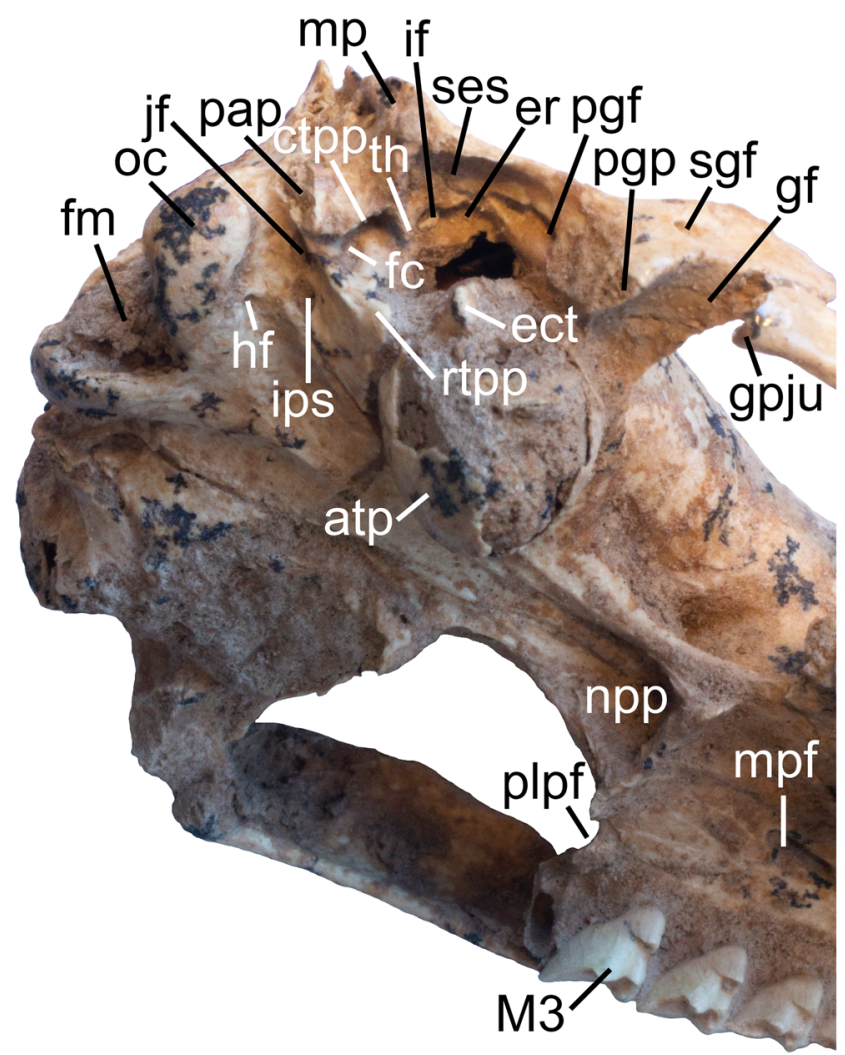

Fig. 10 Posterior part of the cranium of MMP M-5292 (Sparassocynus derivatus) in oblique right posteroventral view. Abbreviations: atp, alisphenoid tympanic process; ctpp; caudal tympanic process of the petrosal; ect; ectotympanic; er; epitympanic recess; fc; fenestra cochleae; $\mathrm{fm}$; foramen magnum; gf, glenoid fossa; gpju, glenoid process of the jugal; hf, hypoglossal foramen; if, incudal fossa; ips, foramen for the inferior petrosal sinus; jf, jugular foramen; M3, third upper molar; mp, mastoid process; mpf, maxillopalatine fenestrae; npp, nasopharyngeal passageway; oc, occipital condyle; pap, paroccipital process of the exoccipital; pgf, postglenoid foramen; pgp, postglenoid process; plpf, posterolateral palatal foramen; rtpp, rostral tympanic process of the petrosal; ses, squamosal epitympanic sinus; sgf, supraglenoid foramen; th, tympanohyal

an "epitympanic sinus." However, it lacks any evidence of dividing septa or obvious diverticula, but appears to be simply a dorsal extension of the primary middle ear cavity (see also comments by Archer 1976a). Although the term "hypotympanic" is arguably objectionable (see MacPhee 1981: 32) because this cavity extends dorsally far above the level of the tympanum in Sparassocynus, and does so to a lesser extent in many other marsupials (e.g., many dasyurids, and the peramelemorphians Isoodon and Macrotis), we refer to the entire space as the hypotympanic sinus to maintain consistency with the majority of the metatherian literature.

The roof of the hypotympanic sinus is formed primarily by alisphenoid, but part of the posterior wall appears to be formed by petrosal. Because the hypotympanic sinus is so inflated dorsally, the alisphenoid roof is in direct contact with the squamosal that forms the external surface of the posterolateral part of the cranium, creating a "double-walled" morphology, as noted by Reig and Simpson (1972: 526). A similar "doublewalled" morphology, again the result of dorsal expansion of the hypotympanic sinus, is seen in the extant dasyurid Sarcophilus harrisii (see Archer 1976a: 258).

The rostral tympanic process of the petrosal extends the entire length of the promontorium, and forms a prominent triangular lamina, the apex of which points laterally (Figs. 8 and 10). Based on MMP S-339, the epitympanic recess and fossa incudis appear to be well excavated dorsally, but they are not hugely expanded as they are in some peramelemorphians (Voss and Jansa 2009). In MMP S-571 and S-339, the geniculate ganglion does not appear to be floored by bone, i.e., there is no true secondary facial foramen distinct from the hiatus Fallopii (although we cannot rule out the possibility that this is due to breakage). The caudal tympanic process appears damaged in MMP M-5292 (Figs. 8 and 10), but in MMP S-339 the caudal tympanic process forms a lamina that contacts, but does not fuse with, the posterior edge of the rostral tympanic process, concealing the fenestra cochleae. Based on MMP material, it is unclear whether or not a prootic canal is present.

The ectotympanic is preserved on the right side of MMP M-5292, but it is embedded within the matrix filling the hypotympanic sinus (Figs. 10 and 11). It appears to be very broad mediolaterally, far broader than that of any extant didelphid, but otherwise its morphology cannot be observed. The ectotympanic of Hesperocynus dolgolpolae is a broad half-cylinder (Simpson 1974; Forasiepi et al. 2009), and is probably indicative of the full morphology of this bone in S. derivatus. In $H$. dolgolpolae, the ectotympanic has a thickened lateral edge (Forasiepi et al. 2009), which probably sat outside the hypotympanic sinus, while the more medial part was within the sinus, enclosed by the alisphenoid tympanic process; if so, this corresponds to the "semiphaneric" condition sensu MacPhee (1981).

The petrosal of MMP M-5292 and of the other S. derivatus specimens examined here has a large mastoid exposure on the occiput, and there is a distinct mastoid process at the ventrolateral corner (Figs. 8, 9, 10, and 11). In MMP M-5292, the supraoccipital contributes to the dorsal margin of the foramen magnum, and there is a distinct incisura occipitalis is present (Fig. 11). Sutures cannot be identified between the supraccipital and exoccipital in either MMP S-571 or MMP S-339, but the incisura occipitalis still appears to be identifiable, suggesting that the supraoccipital probably contributes to the dorsal margin of the foramen magnum in the adults too, as in most extant didelphids, but unlike the condition in Didelphis, Lutreolina, Metachirus, and Philander (Voss and Jansa 2009). The paroccipital process (= "paracondylar process" sensu Wible 2003) of the exoccipital is relatively low and rounded in MMP M-5292 (Figs. 8, 10, and 11), MMP S-571 (Fig. 9), and MMP S-339, again as in most extant didelphids, whereas it is tall and erect in Chironectes, 


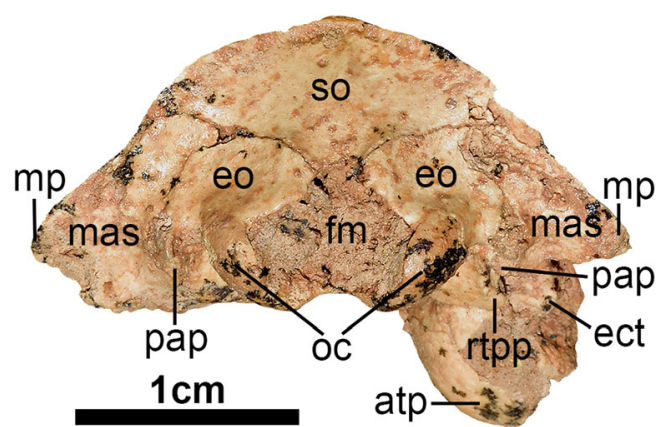

Fig. 11 Cranium of MMP M-5292 (Sparassocynus derivatus) in posterior view. Abbreviations: atp, alisphenoid tympanic process; ect; ectotympanic; eo, exoccipital; fm, foramen magnum; mas, mastoid exposure of the petrosal; mp, mastoid process; oc, occipital condyle; pap, paroccipital process of the exoccipital; rtpp, rostral tympanic process of the petrosal; so, supraoccipital

Didelphis, Lutreolina, Metachirus, and Philander (see Voss and Jansa 2009).

Mandible The left and right mandibles are largely intact, except that the dorsal part of the coronoid process is missing on the left side, and the entire coronoid process and most of the angular process is missing on the right (Figs. 12, 13, and 14). The symphysis is unfused. On the left mandible of MMP M-5292, there are three mental foramina: one large foramen below $\mathrm{p} 1$, and two smaller foramina more posteriorly, below the anterior root of $\mathrm{dp} 3$ and below the posterior root of $\mathrm{m} 1$. On the right mandible, there are two mental foramina, one large one below the posterior root of p2 and one small one below the posterior root of $\mathrm{m} 1$. The angular process is welldeveloped and strongly inflected medially. There are no foramina within the retrodental space.

\section{Phylogenetic Analysis}

The undated (Fig. 15) and dated (Fig. 16) phylogenetic analyses both strongly support $(\mathrm{BPP}=1.00)$ monophyly of Didelphidae, with Sparassocynus and Hesperocynus within this clade. Both analyses support the following four morphological character states as unambiguous (i.e., supported under both Accelerated and Delayed Transformation) synapomorphies of Didelphidae (Electronic Supplementary Material, Table S2): tail scales in annular and spiral series; presphenoid exposed in roof of nasopharyngeal orifice above posterior palatal margin; P2 and P3 subequal in height; p2 distinctly lower than $\mathrm{p} 3$. None of these characters could be scored in Hesperocynus, and tail scale morphology is unknown in Sparassocynus. However, the presphenoid is exposed above the posterior palatal margin in Sparassocynus (i.e., it shows the synapomorphic state for Didelphidae), but it does not retain the other two didelphid synapomorphies: instead, its P3 is taller than P2, and its p2 and p3 are subequal in height (see "Description" above).

Relationships within Didelphidae closely resemble the results of recent molecular and total evidence analyses (e.g., Voss and Jansa 2009; Jansa et al. 2014; Díaz-Nieto et al. 2016), and most nodes are strongly supported (BPPs $>0.95$ ). In terms of the relationships among extant didelphids, the only major difference between the two is the position of Tlacuatzin: it is sister to Marmosa (including Micoureus) in the undated analysis, but sister to Monodelphis + Marmosa+ Sparassocynus + Hesperocynus in the dated analysis.

Both analyses recover Sparassocynus and Hesperocynus in a strongly supported clade (BPP $=1.00)$ united by five unambiguous synapomorphies (Electronic Supplementary Material, Table S2); they also strongly support a close relationship between this clade and the genus Monodelphis (BPP $=1.00)$, supported by ten (in the undated analysis) or six (in the dated analysis) unambiguous synapomorphies (Electronic Supplementary Material, Table S2). However, the two analyses differ in terms of the precise relationship between Sparassocynus + Hesperocynus and Monodelphis. The undated analysis weakly supports Sparassocynus + Hesperocynus within a paraphyletic Monodelphis, as sister to the extant species $M$. peruviana $(\mathrm{BPP}=0.5)$. This Sparassocynus + Hesperocynus $+M$. peruviana clade is united by a single unambiguous synapomorphy, namely absence of contact between the parietal and mastoid, due to
Fig. 12 Left and right mandibles of MMP M-5292 (Sparassocynus derivatus) in dorsal view.

Abbreviations: ang, angular process; c1, lower canine; con, mandibular condyle; dp3, third lower deciduous premolar; i1, first lower incisor; i4, fourth lower incisor; $\mathrm{m} 4$, fourth lower molar; psmf, posterior shelf of the massteric fossa

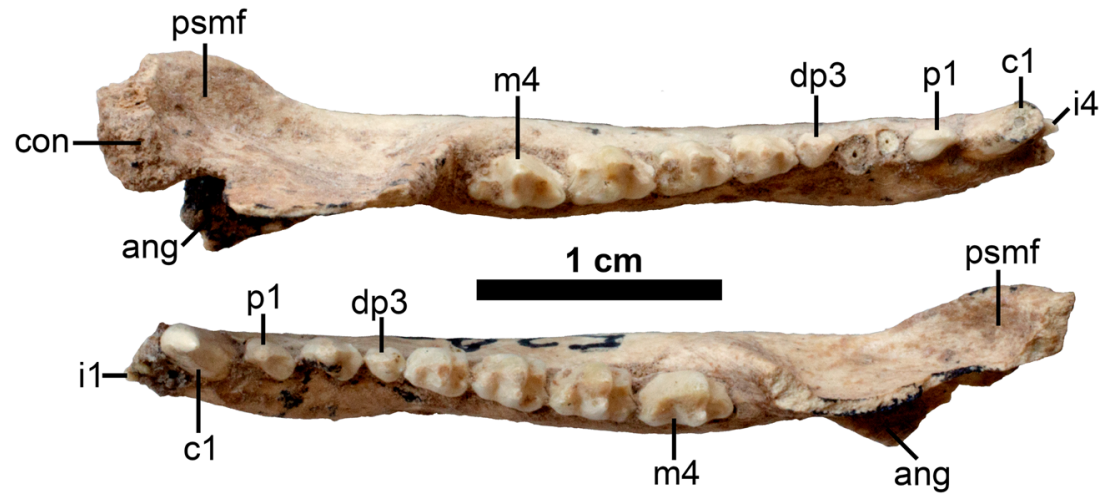

Springer 
Fig. 13 Left and right mandibles of MMP M-5292 (Sparassocynus derivatus) in lateral view.

Abbreviations: ang, angular process; c1, lower canine; coc, coronoid crest; con, mandibular condyle; cor, coronoid process; $\mathrm{dp} 3$, third lower deciduous premolar; i4, fourth lower incisor; $\mathrm{m} 4$, fourth lower molar; maf, masseteric fossa; $\mathrm{mf}$, mental foramen; p1, first lower premolar; psmf, posterior shelf of the masseteric fossa

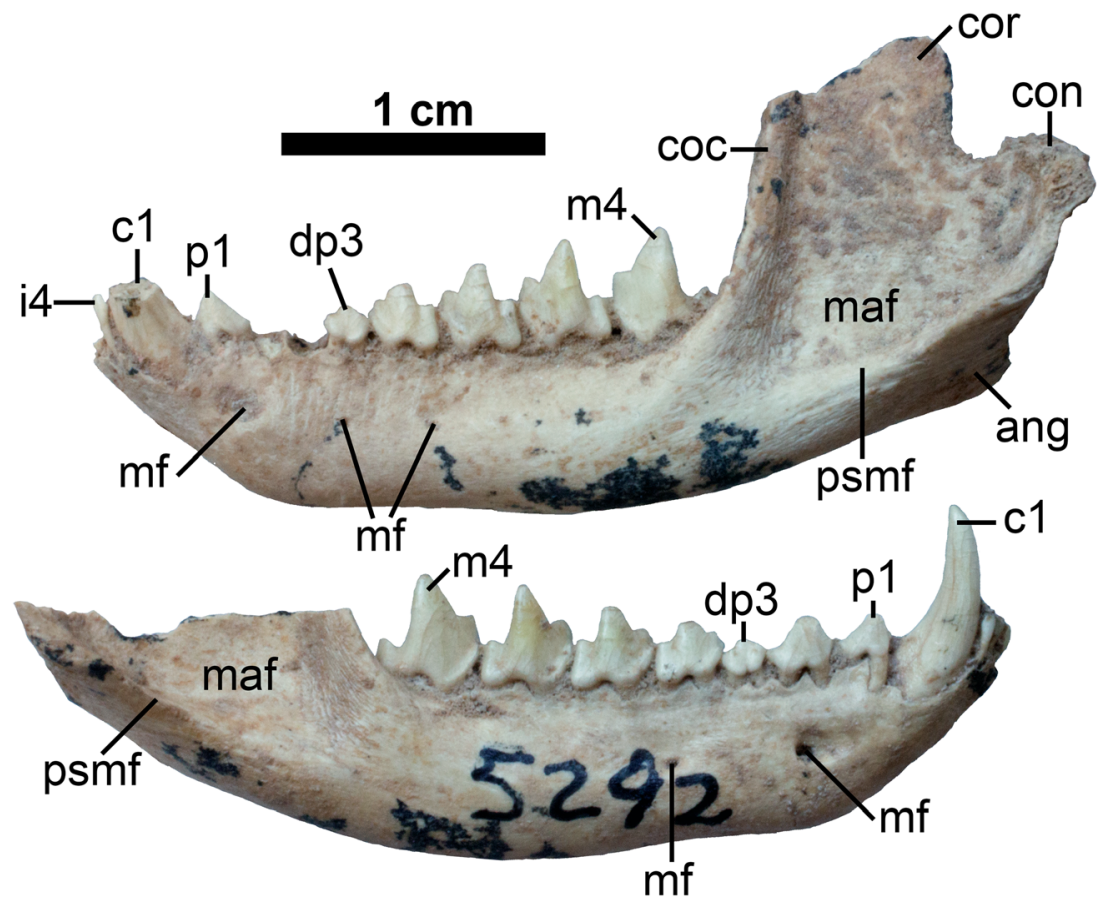

squamosal-interparietal contact. Monodelphis peruviana is the only Monodelphis species sampled by Voss and Jansa (2009) to consistently exhibit squamosal-interparietal contact, a feature shared with Sparassocynus (the condition in Hesperocynus is unknown). However, it also occurs in some specimens of M. brevicaudata and M. emiliae (see Voss and Jansa 2009), as well as in several other Monodelphis species not included by Voss and Jansa (2009), namely members of the "Adusta group," such as M. handleyi (see Pavan and Voss 2016). By contrast, the dated analysis places Sparassocynus + Hesperocynus as sister to a monophyletic Monodelphis. The Monodelphis clade received relatively strong support (BPP =
0.87 ), but is characterized by only one unambiguous synapomorphy, namely absence of distinct postorbital processes, whereas Sparassocynus has very large postorbital processes (the condition in Hesperocynus is currently unknown).

The difference in topology between the undated and dated analyses appears to be related to the highly apomorphic morphology of Sparassocynus and Hesperocynus, as indicated by the long branch leading to these taxa in the undated analysis (Fig. 15). In the dated analysis, the rate of morphological change along the branch leading to Sparassocynus and Hesperocynus is estimated as $0.91 \% / \mathrm{Ma}$ (Fig. 17 left), which is the highest rate of any branch, but only $\sim 1.5 \mathrm{x}$ higher than
Fig. 14 Left and right mandibles of MMP M-5292 (Sparassocynus derivatus) in medial view. Abbreviations: ang, angular process; c1, lower canine; con, mandibular condyle; dp3, third lower deciduous premolar; il, first lower incisor; i4, fourth lower incisor; $\mathrm{m} 4$, fourth lower molar; manf, mandibular foramen; mas, mandibular symphysis; $\mathrm{p}$ 1, first lower premolar

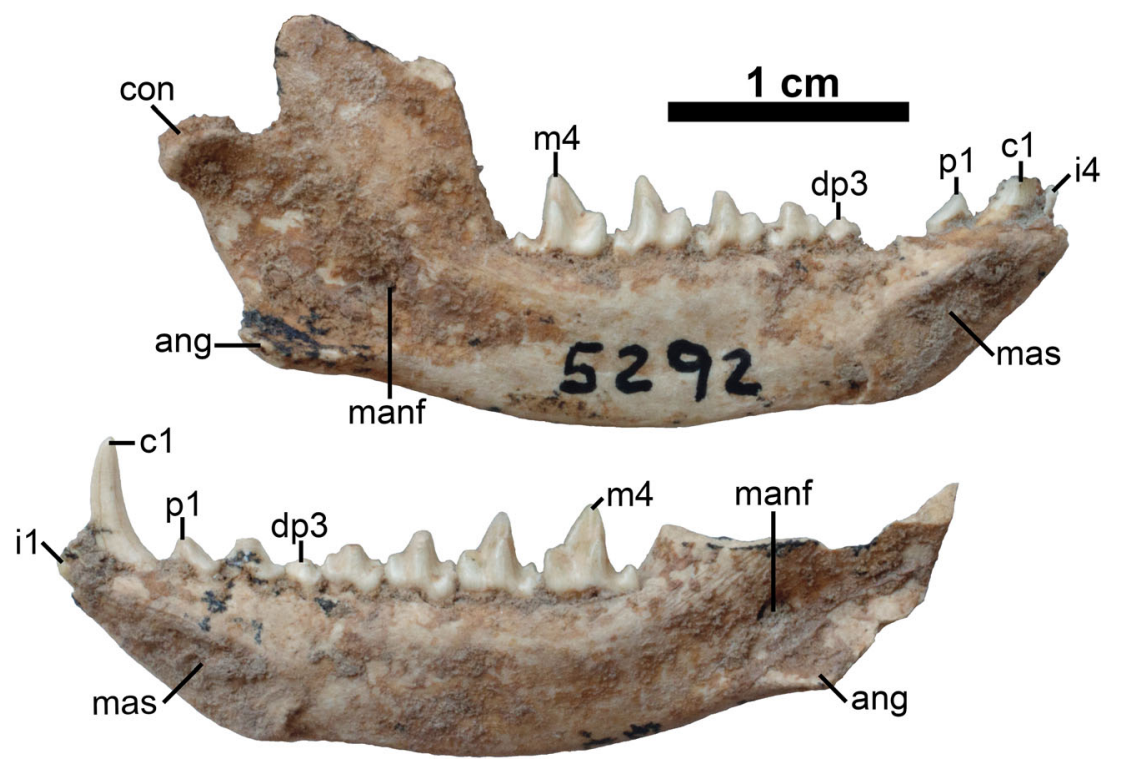


Fig. 15 Phylogeny of Didelphidae based on Bayesian undated analysis of total evidence dataset using MrBayes 3.2.6. The dataset comprises 128 morphological characters and $7320 \mathrm{bp}$ from five nuclear protein-coding genes (BRCA1, DMP1, RBP3, RAG1 and VWF). The topology represents a $50 \%$ majority rule consensus tree of post-burn-in trees, with nondidelphimorphian outgroups not shown. Branch lengths are measured in expected changes per character. Sparassocynus derivatus and Hesperocynus dolgopolae are shown in bold. Abbreviations: BPP, Bayesian posterior probability

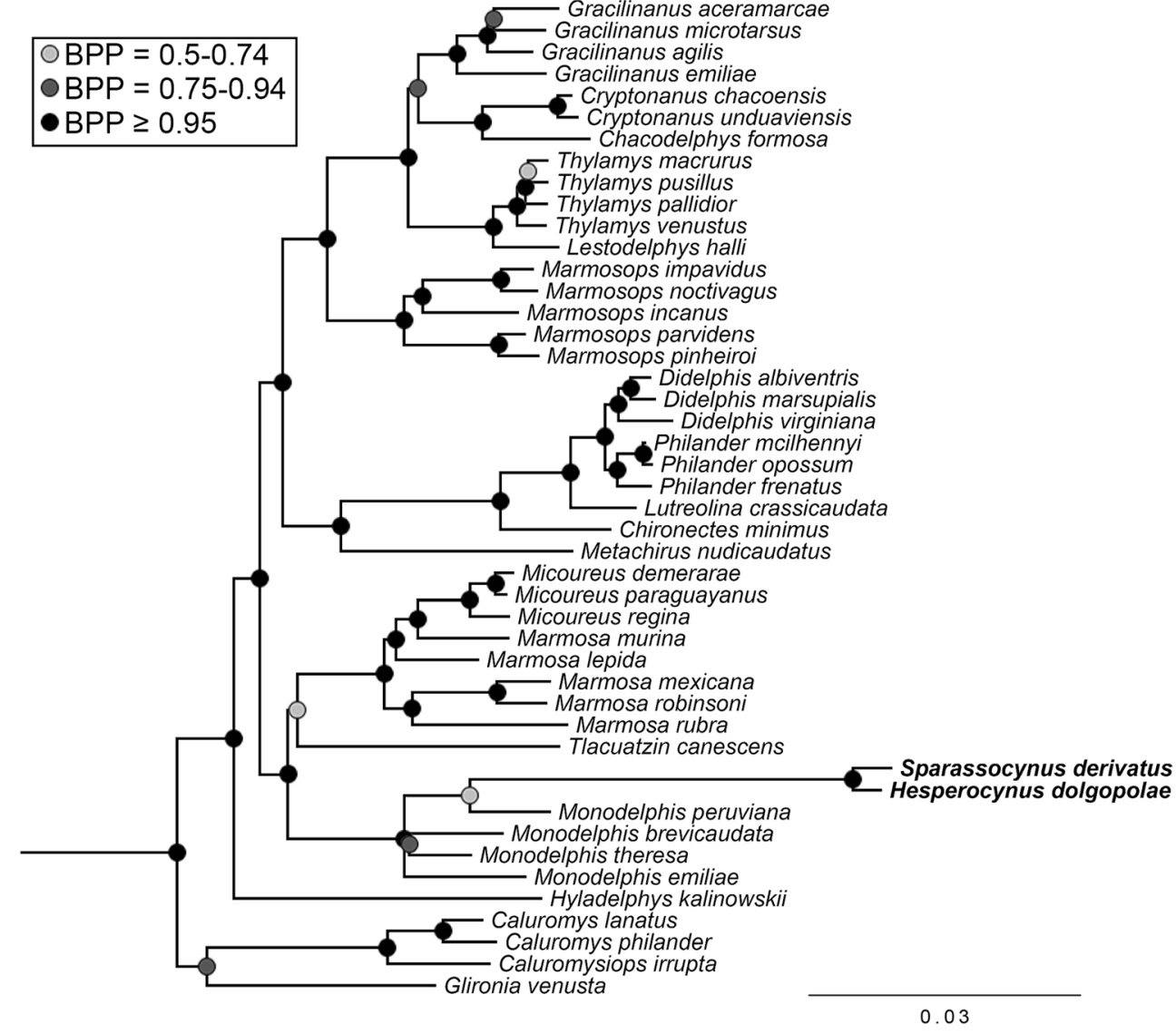

the next fastest branch (mean rate across all branches $=0.12 \%$ / $\mathrm{Ma}$; s.d. = 0.16). Repeating the dated analysis with Sparassocynus + Hesperocynus constrained to be sister to M. peruviana (i.e., to match the undated topology; Fig. 17 right) results in the rate of morphological change along the branch leading to Sparassocynus + Hesperocynus of $2.87 \%$ / $\mathrm{Ma}$, which is $\sim 3.5 \mathrm{x}$ faster than the next highest rate (mean rate across all branches $=0.16 \% / \mathrm{Ma}$; s.d. $=0.30)$.

Divergence dates in the dated analysis (Table 1) are comparable to those of Jansa et al. (2014), suggesting that Didelphidae originated 24.3 MYA (95\% HPD: 19.0-30.5 MYA). Sparassocynus + Hesperocynus is estimated as having split from the Monodelphis lineage 10.5 MYA (95\% HPD: 7.2-16.0 MYA). Use of a fossilized birth-death prior with "diversity" sampling allows for the possibility of fossil taxa being direct ancestors, and the zero-length branch leading to Hesperocynus in the dated analysis (Fig. 16) indicates that it is plausibly ancestral to Sparassocynus.

A Lineage Through Time plot of extant didelphids (i.e., with non-didelphid outgroups, Sparassocynus and Hesperocynus removed; Fig. 18) shows a prolonged period of zero net diversification previously identified by Jansa et al. (2014); it is estimated here to have spanned 15.0-10.3 MYA (95\% HPD: 18.9-7.9 MYA). Interestingly, this period largely overlaps with the estimated age of origin of the Sparassocynus + Hesperocynus lineage. It also coincides with a major drop in global temperatures (the mid-Miocene Climatic Transition) 14 MYA (Fig. 18; Hansen et al. 2013). In addition, sparassodonts appear to have declined in diversity at about this time (Fig. 18), at some point between the Santacrucian ( 18-15.6 MYA; Cuitiño et al. 2016) and Huayquerian SALMAs, although the exact timing of this decline remains uncertain (Prevosti et al. 2013; Engelman and Croft 2014; López-Aguirre et al. 2017; Croft et al. 2018).

\section{Discussion}

Cranial Morphology and Phylogenetic Affinities of Sparassocynus and Hesperocynus Fusion of the interparietal with the supraoccipital, which is clearly present in the Sparassocynus derivatus specimen described here (MMP M-5292), is a distinctive cranial feature that we have observed only in didelphids (see Nesslinger 1956; Clark and Smith 1993; Voss and Jansa 2009) and dactylopsiline petaurids (pers. obv.) among metatherians. Dactylopsilines are diprotodontian marsupials, and are otherwise radically different from Sparassocynus in terms of their craniodental anatomy. Its 


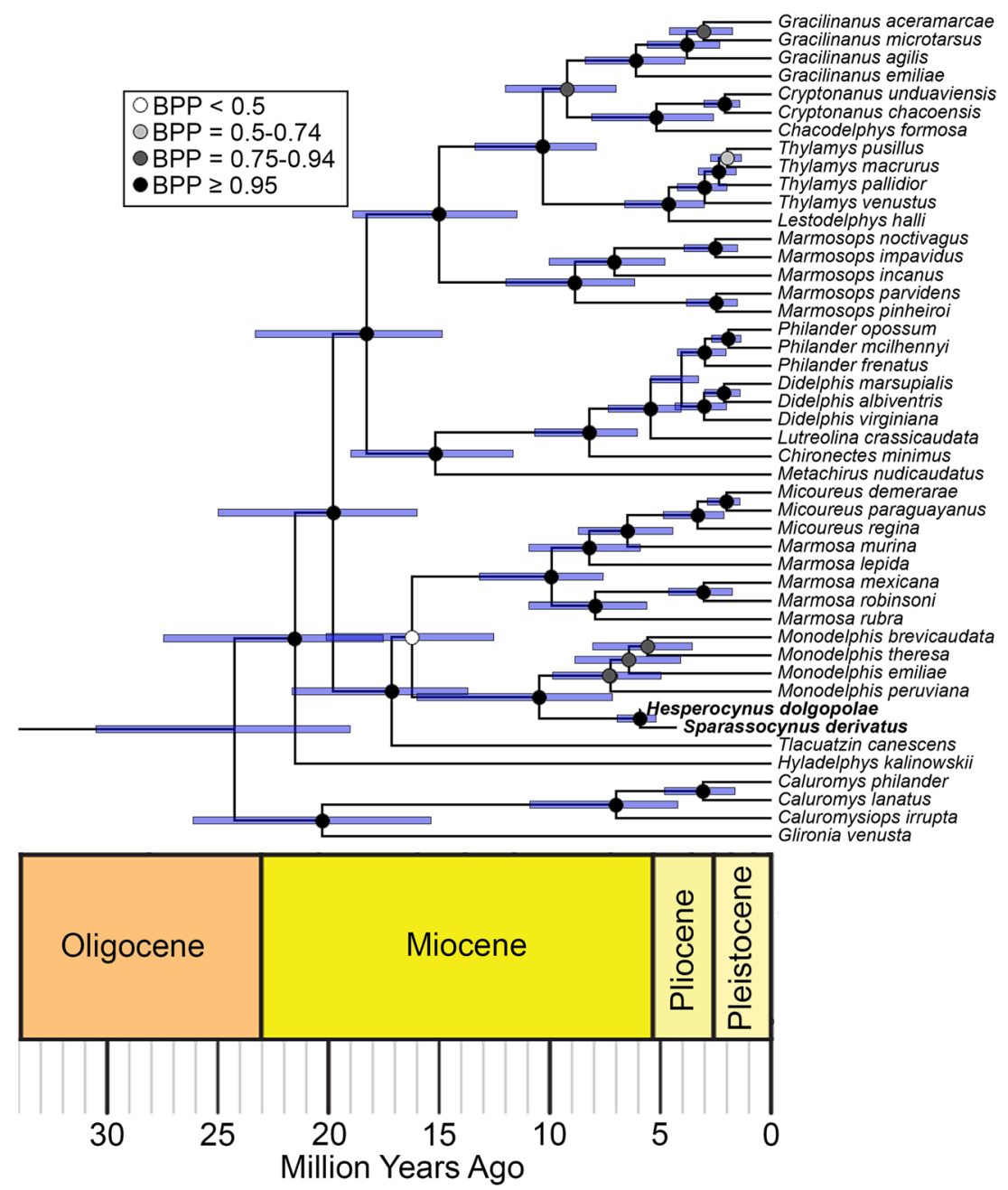

Fig. 16 Phylogeny of Didelphidae based on Bayesian "tip-and-node dating" analysis of total evidence dataset using MrBayes 3.2.6. The dataset comprises 128 morphological characters and $7320 \mathrm{bp}$ from five nuclear protein-coding genes (BRCA1, DMP1, RBP3, RAG1 and VWF), assuming separate Independent Gamma Rates (IGR) clock models for the morphological and molecular partitions, "diversity" sampling, and with temporal information provided in the form of tip ages and also constraints on the ages of selected nodes. The topology represents a maximum clade credibility (MCC) tree, with non-didelphimorphian outgroups not shown. Nodes without Bayesian posterior probabilities were used as age constraints, which required them to be constrained as monophyletic a priori. Blue bars at nodes represent 95\% Highest Posterior Densities (HPDs) on node ages. Sparassocynus derivatus and Hesperocynus dolgopolae are shown in bold. Abbreviations: BPP, Bayesian posterior probability presence in Sparassocynus seems strong evidence that this taxon is member of Didelphimorphia sensu stricto. The presphenoid of Sparassocynus is also exposed in the roof of the nasopharyngeal orifice, above the posterior palatal margin, as in extant didelphids, but unlike the non-didelphids examined by Voss and Jansa (2009), namely caenolestids, dasyurids, and peramelids, in which it is concealed by the vomer.

Other probable apomorphies present in Sparassocynus suggest that it falls within crown-clade Didelphidae. These include the presence of a posterior palate with distinct corners, which is a synapomorphy of Hyladelphinae+Didelphinae, and contact between the maxilla and alisphenoid, which is seen in Monodelphis and Lutreolina but no other extant didelphids (Voss and Jansa 2003, 2009); among other metatherians, we have seen this latter feature only in some diprotodontians. Sparassocynus shares with didelphins the absence of a lingual cusp or heel on the lower incisors, and also fusion of the midfrontal suture, while Sparassocynus and Hesperocynus resemble Chacodelphys, Lestodelphys, Lutreolina, and Monodelphis in that the hypoconid is lingual to the protoconid, and many extant didelphids share with Sparossocynus the presence of only two distinct cuspids on the trigonid of $\mathrm{dp} 3$; however, all of these latter apomorphic features are also seen in some non-didelphid metatherians (Voss and Jansa 2009; pers. obv.).

The auditory region of Sparassocynus differs radically from those of all extant didelphids, as has been discussed by many previous authors (e.g., Reig 1958b; Reig and Simpson 1972; Simpson 1972, 1974; Archer 1976a; Forasiepi et al. 


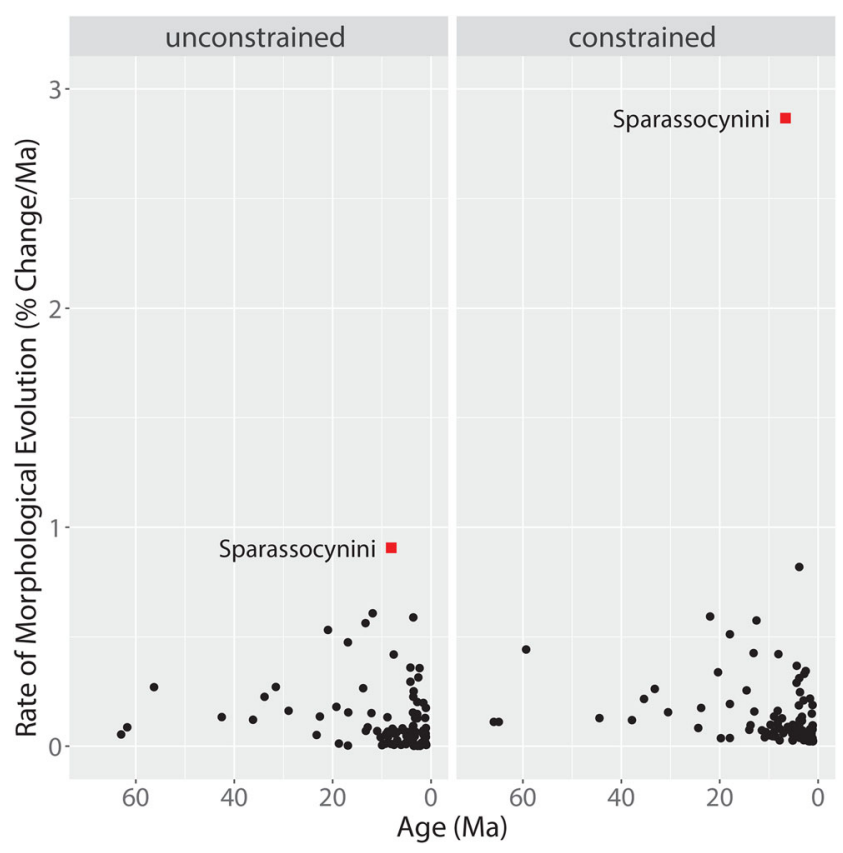

Fig. 17 Comparison of rates of morphological evolution among didelphids based on Bayesian "tip-and-node" dating analysis of total evidence dataset using MrBayes 3.2.6. Left ("Unconstrained") shows rates when the topology was unconstrained (see Fig. 12). Right ("Constrained") shows rates when the topology was constrained to match that seen in the undated analysis, in which the sparassocynins Sparassocynus derivatus and Hesperocynus dolgopolae form a clade with Monodelphis peruviana (see Fig. 13). The branch leading to Sparassocynini is highlighted in red

2009): most obviously, it is far more inflated in Sparassocynus than in any extant didelphid, with the hypotympanic sinus extending far dorsally either side of the endocranial cavity (see "Description" above). This morphology is evidently also present, although not quite as well-developed, in Hesperocynus dolgopolae (see Simpson 1974; Forasiepi et al. 2009). Species of another carnivorously-adapted Neogene didelphimorphian genus from Argentina, Hyperdidelphys, also have hypotympanic sinuses that are larger than any extant didelphid: they are moderately large in the Huayquerian species $H$. pattersoni, and reach an extreme in the Chapadmalalan species $H$. dimartinoi (see Goin and Pardiñas 1996; Goin et al. 2016: fig. 5.5). Voss and Jansa (2009: 100) reported that Hyperdidelphys is a didelphine, while Goin and Pardiñas (1996) concluded that it is probably most closely related to Lutreolina among extant didelphids. Regardless, it does not appear to be closely related to Sparassocynus or Hesperocynus. An undescribed specimen (MMP 2598-M) of Thylophorops chapadmalensis (a probable didelphin; Voss and Jansa 2009) from the Chapadmalal Formation shows that this taxon also has auditory bullae that are larger than those of any extant didelphid (R. S. Voss, pers. comm.). Thus, it seems that, during the Neogene, multiple didelphid lineages independently evolved hypotympanic sinuses that are markedly larger than those of extant didelphids.

Another major difference between Sparassocynus and most extant didelphids is the presence of a well-developed epitympanic sinus (see "Materials and Methods: Anatomical Terminology") in the squamosal, posterolateral to the epitympanic recess. The entrance of this sinus was probably covered by the pars flaccida of the tympanum in life, as in dasyuromorphians and in those peramelemorphians in which the sinus is present (Archer 1976a). Based on available material, it is uncertain whether or not a similar sinus was present in Hesperocynus. Most, but not all, extant Australian marsupials have a well-developed squamosal epitympanic sinus posterolateral to the epitympanic recess, and this feature may even represent a synapomorphy of the extant Australian radiation (= Eomarsupialia sensu Beck et al. 2014; Marshall et al. 1990; but see Godthelp et al. 1999); regardless, its presence in Sparassocynus is almost certainly homoplastic.

There is disagreement in the literature as to whether any extant didelphids have a structure that can reasonably be described as a squamosal epitympanic sinus (Archer 1976a, 1982; Wible 1990; Voss and Jansa 2009). We agree with Archer (1976a: 304), who reported that "[i]n some didelphids (e.g., Metachirus) there is a depression in the squamosal which is clearly the homologue of this sinus" (see also Archer 1982: 461; Reig et al. 1987: figs. 39-44), and incompletely cleaned didelphid crania (e.g., AMNH M-212909, a specimen of Chironectes minimus) suggest that, where present, this depression may be covered by the pars flaccida; however, if present at all, this depression is usually very weakly developed. The sole exception to this among extant didelphids is Caluromysiops irrupta, in which a prominent, wellexcavated epitympanic sinus is present within the squamosal, posterolateral to the epitympanic recess (see Reig et al. 1987: fig. 44c). The presence of an epitympanic sinus in Caluromyisops was also noted by Wible (1990: 200), who referred to it as a "suprameatal fossa," following Segall (1943; see "Materials and Methods: Anatomical Terminology" above).

Reig and Simpson (1972) noted several similarities between the auditory region of Sparassocynus and that of dasyurids, especially Dasyuroides and Dasycercus, which have particularly inflated auditory sinuses. However, there are some key differences, notably in that the rostral and caudal tympanic processes of the petrosal are closely approximated, but still separated by a distinct gap, in Sparassocynus, whereas in all extant dasyurids these processes are fused, forming a "petrosal plate" sensu MacPhee (1981; Archer 1976a; Wroe 1999; Sánchez-Villagra and Wible 2002; Ladevèze et al. 2008; Voss and Jansa 2009).

A distinctive apomorphy of Sparassocynus (and apparently also Hesperocynus; Forasiepi et al. 2009) is the path of the mandibular division of the trigeminal nerve $\left(\mathrm{V}_{3}\right)$ after it leaves 


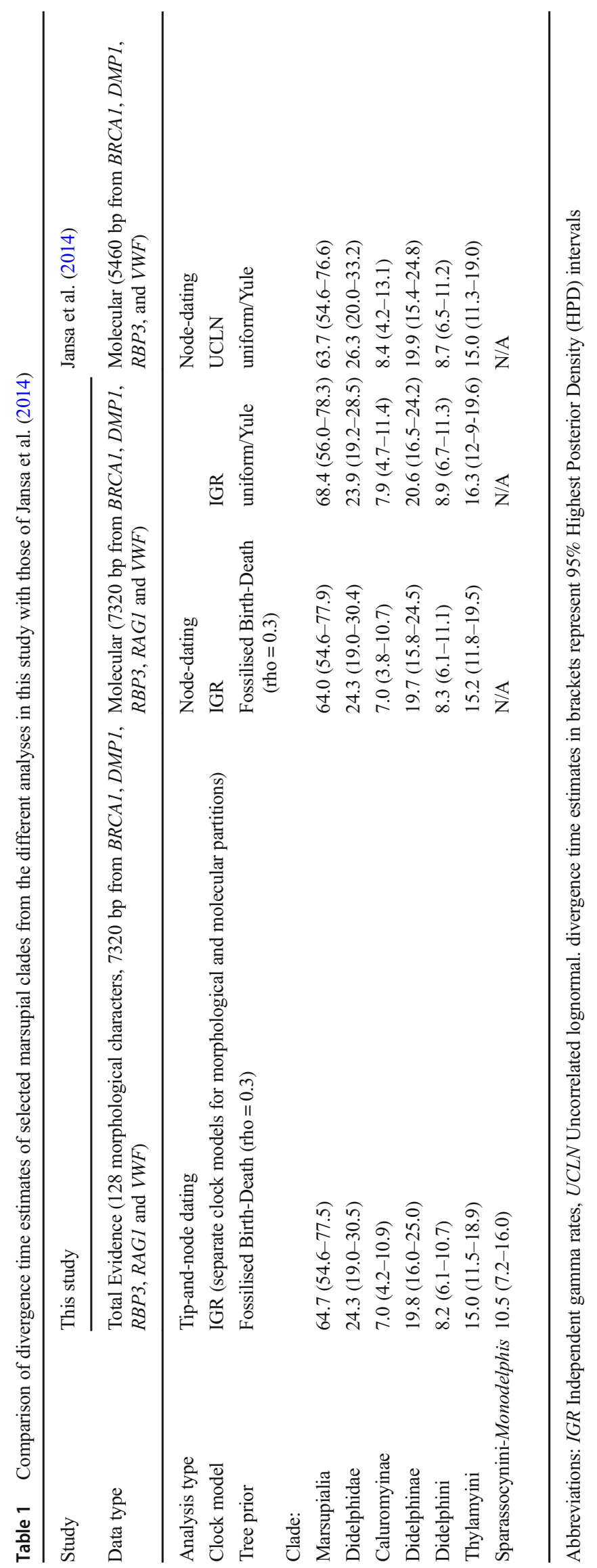




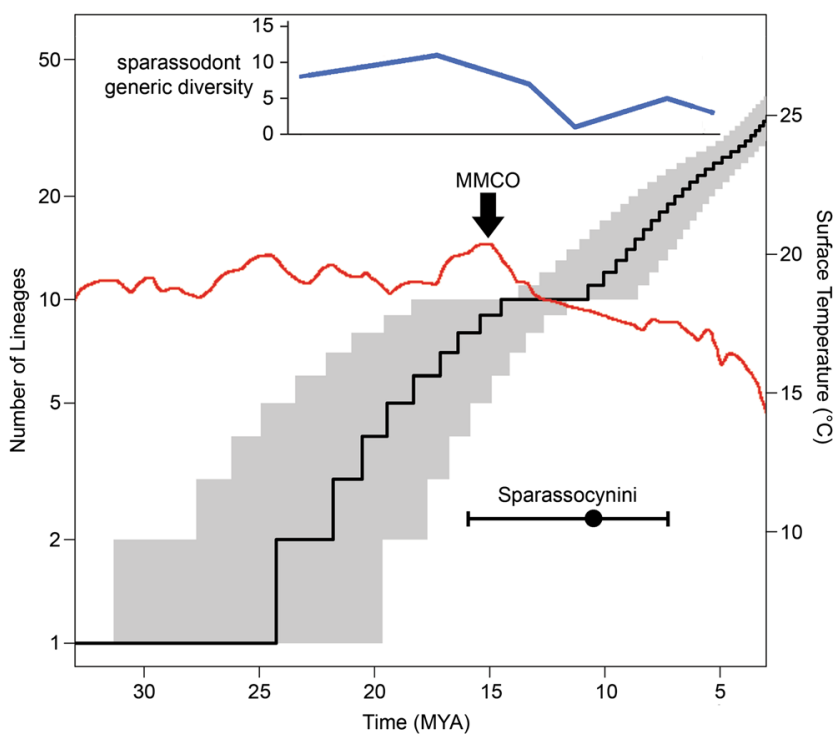

Fig. 18 Composite figure showing Lineage Through Time plot for extant didelphids (Center: black line $=$ median, grey shading $=95 \%$ confidence interval), estimated divergence time for the origin of Sparassocynini (Lower Right: black circle $=$ point estimate, black lines $=95 \%$ HPD), global surface temperature (Center: red line =global surface temperature estimate from Hansen et al. [2013: fig. 4a], "MMCO"= middle Miocene Climatic Optimum), and diversity of sparassodonts through time (Top: blue line $=$ sparassodont generic diversity from the early Miocene to the early Pliocene, modified from Croft et al. [2018: fig. 2a])

the endocranial cavity, namely within a bony canal in the medial wall of the hypotympanic sinus, formed by the alisphenoid (Fig. 9); it has no close counterpart in either extant didelphids or dasyurids, in which this nerve is either unenclosed after it exits the endocranium, or is enclosed by a simple strut or lamina of the alisphenoid tympanic process (Wroe 1997; Voss and Jansa 2003, 2009). In fact, the closest resemblance within metatherians is seen in phascolarctids (the extant koala and fossil relatives), although here the mandibular division of the trigeminal nerve is enclosed within a bony canal in the roof of the hypotympanic sinus, rather than in the medial wall (Aplin 1987, 1990; Louys et al. 2009). The condition seen in Sparassocynus and Hesperocynus may represent a plausible structural (although clearly not phylogenetic) ancestral morphology for the phascolarctid condition: progressive medial expansion of the hypotympanic sinus first leads to the mandibular division of the trigeminal nerve being incorporated into the medial wall of the sinus (the condition in Sparassocynus and Hesperocynus), with further medial expansion leading to the development of a nerve canal in the roof of the sinus (the phascolarctid condition).

In summary, qualitative interpretation of the known morphology of Sparassocynus and Hesperocynus suggests that they are probably members (albeit highly autapomorphic ones) of the didelphimorphian crown-clade, i.e., Didelphidae. This conclusion is confirmed by our Bayesian undated and dated total evidence phylogenetic analyses, both of which strongly support monophyly of Didelphidae with Sparassocynus and Hesperocynus within this clade (BPP = 1.00 ), with these two genera forming a strongly-supported clade with the extant genus Monodelphis $(\mathrm{BPP}=1.00)$, within the subfamily Didelphinae $(\mathrm{BPP}=1.00)$. Interparietalsupraoccipital fusion was not recovered as a synapomorphy of Didelphidae in our analyses, because the condition in caenolestids Caenolestes and Rhyncholestes (used as two of the seven outgroup taxa here) is unknown (Voss and Jansa 2009: 36). However, exposure of the presphenoid in the roof of the nasopharyngeal orifice above the posterior palatal margin (present in Sparassocynus) was found to be an unambiguous synapomorphy of Didelphidae, and presence of a posterior palate with corners (also present in Sparassocynus) was an unambiguous synapomorphy for Hyladelphinae+ Didelphinae (Electronic Supplementary Material, Table S2).

Based on these results, recognition of the distinct family Sparassocynidae is unjustified; instead, we argue that, within the taxonomic framework proposed by Voss and Jansa (2009), they are most appropriately classified as a tribe, Sparassocynini, within Didelphidae. However, as already noted (see "Materials and Methods: Systematics" above), this would also require raising the Monodelphis and possibly also the Tlacuatzin lineages to tribal rank, as Monodelphini and Tlacuatzini, respectively.

Differences between Undated and Dated Bayesian Phylogenetic Analyses The position of Sparassocynus and Hesperocynus differs markedly between the undated and dated phylogenetic analyses: they form a clade with Monodelphis peruviana in the undated analysis, but are placed as sister to a monophyletic Monodelphis in the dated analysis. Each of these arrangements is supported by a single unambiguous synapomorphy, but support for the Sparassocynus + Hesperocynus + M. peruviana clade found in the undated analysis is much lower $(\mathrm{BPP}=0.5)$ than that for the Monodelphis clade found in the dated analysis $(\mathrm{BPP}=0.87$ ). The difference in topology between the two analyses seems to be related to the highly autapomorphic morphology of sparassocynins, as indicated by their very long branch in the undated analysis (Fig. 15). Clock models (whether for molecular, morphological, or total evidence data) assume that evolutionary change is proportional to time (Zuckerkandl and Pauling 1965; Ronquist et al. 2012a). Relaxed clock models allow evolutionary rate to vary somewhat between branches, but they still tend to disfavor extreme rate variation (Beck and Lee 2014; Beaulieu et al. 2015; Phillips and Fruciano 2018). Presumably, the extreme morphological rate variation implied by the undated topology (specifically, the much higher rate along the Sparassocynus + Hesperocynus branch than anywhere else in the tree; Fig. 17) is too high to be accommodated by the IGR clock model in the dated analysis, and so the 
Sparassocynus + Hesperocynus clade is shifted deeper within the tree, yet still closely related to Monodelphis, with which it shares numerous synapomorphies (Electronic Supplementary Material, Table S2).

Our results agree with other recent studies that have found that dated Bayesian analyses of datasets that include fossil taxa (whether as tip-dating, or, as here, in combined tip-andnode dating) can result in major topological differences relative to undated analyses (King et al. 2017; Turner et al. 2017; Lee and Yates 2018). In cases where dated and undated analyses show major topological differences, whether one should be consistently preferred over the other is currently an open question. However, if there is a broad relationship between time and morphological change (as there undoubtedly is for time and molecular change), then, ceteris paribus, we might expect dated analyses to result in more accurate phylogenies than their undated equivalents (see also Lee and Yates 2018). Some support for this assumption is provided by simulation studies by King et al. (2017), who found that Bayesian tipdating outperformed (undated) parsimony; however, they did not investigate the performance of undated Bayesian analysis.

Having said that, there may be periods of time (perhaps very short) where rates of morphological evolution might be much higher than at other times, for example in the aftermath of a mass extinction event, when lineages evolve rapidly to fill newly vacant ecological niches. In such cases, current clock models might be too restrictive, overly "smoothing" this extreme rate variation (see e.g., Beck and Lee 2014; Beaulieu et al. 2015; Phillips and Fruciano 2018); future clock models might incorporate Lévy processes (see also Waddell 2008), which can allow sudden evolutionary "jumps" and which have already been used to model trait evolution (Landis et al. 2013; Duchen et al. 2017). Further studies are clearly needed to investigate the behavior of clock models with morphological and total evidence data (Parins-Fukuchi and Brown 2017). In the meantime, for datasets that include fossil taxa, we recommend that authors should carry out both undated and dated analyses, to determine whether they result in very different topologies.

\section{Divergence Dates and Diversification of Didelphimorphia Our} estimated dates for divergences within Didelphidae are broadly similar to those of Jansa et al. (2014; see Table 1), but considerably younger than those of several other molecular clock studies (Steiner et al. 2005; Meredith et al. 2008, 2011; Mitchell et al. 2014; Vilela et al. 2015; Dias and Perini 2018). Our use of a total evidence dataset and tip-andnode dating (rather than a molecular-only dataset with node dating) does not seem to be the major driver for the younger dates, because repeating our dated analysis using molecular data only resulted in very similar estimates (Table 1). Our divergence estimates for the molecular-only analysis were also almost identical regardless of whether a fossilized birth- death or a Yule (= uniform) prior on tree shape was used (Table 1), suggesting that the tree prior does not explain our younger dates either (contra the findings of Condamine et al. 2015; Matzke and Wright 2016; Zhang et al. 2016). Instead, they are presumably due to our choice of fossil calibrations, and also differences in clock models and programs between analyses (see Inoue et al. 2010; Barba-Montoya et al. 2017). Pending a detailed exploration of these discrepancies, the divergence dates presented here should be viewed as tentative. However, they match well with Goin's $(1991,1995)$ proposal that extant didelphids represent a comparatively young, Neogene radiation. We use our dated phylogeny, in combination with additional fossil and paleoenvironmental evidence, to propose a revised scenario for the diversification of Didelphimorphia.

Similar to Jansa et al. (2014), we find evidence of a long branch between the divergence of Didelphimorphia from other marsupials (59.8 MYA; 95\% HPD: 48.1-72.9 MYA) and the first diversification within Didelphidae (24.3 MYA; 95\% HPD: 19.0-30.5 MYA). This implies either extensive extinction within Didelphimorphia, with the total loss of earlybranching lineages, or (less likely) that there are additional, deep-diverging didelphimorphian lineages that are still extant but have yet to be discovered. Assuming the former explanation is correct, then an obvious potential driver of extinction within Didelphimorphia is the major drop in global temperatures and associated environmental change that occurred at the Eocene-Oligocene boundary (Hansen et al. 2013). This event coincided with extensive turnover in South American mammal faunas, with the loss of many marsupialiform lineages (Goin et al. 2010a, 2012, 2016, in press). Competition from platyrrhine primates and caviomorph rodents, both of which appear to have reached South America during the middle-tolate Eocene (Antoine et al. 2011; Bond et al. 2015; Boivin et al. 2017), could potentially also have played a role, particularly if the extinct didelphimorphian lineages included forms that were more specialized for frugivorous or herbivorous diets than are extant didelphids (Gardner 2008). However, our understanding of the early diversification dynamics of Didelphimorphia is hampered by the difficulty in unequivocally distinguishing didelphimorphians from other dentally plesiomorphic crown- and stem-marsupials, particularly when only isolated dental remains are available (Voss and Jansa 2009).

We date the origin of Didelphidae to the Oligocene or early Miocene (24.3 MYA; 95\% HPD: 19.0-30.5 MYA; Table 1). Goin et al. (2007a) identified the oldest known putative didelphids based on isolated dental specimens from Level C of the Lower Fossil Zone of the Colhue-Huapi Member of the Sarmiento Formation in southern Argentina. This is the type locality of the Colhuehuapian SALMA and is estimated to span 21.0-20.1 MYA (Dunn et al. 2012). The specimens include a small taxon that Goin et al. (2007a) suggested, based 
on its very small entoconid, may be a plesiomorphic relative of Monodelphis and Thylatheridium (i.e., a member of Monodelphini). However, it should be noted that reduction of the entoconid is homoplastic within Didelphidae: among extant didelphids, a small entoconid is also seen in Chacodelphys (Voss et al. 2004; Voss and Jansa 2009), which is a member of Thylamyini, not Monodelphini (Díaz-Nieto et al. 2016). Goin et al. (2007a) also identified a second Colhue-Huapi taxon as a possible caluromyine. These Colhue-Huapi specimens largely postdate our estimate for the origin of Didelphidae, and so could represent very early representatives of the family. However, our point estimates for the vast majority of divergences within Didelphidae (including the origin of both Monodelphini and Thylamyini) are younger than the Colhuehuapian. In any case, the referral of these highly fragmentary remains to Didelphidae is uncertain; the putative caluromyine, for example, may in fact be a microbiotherian (Goin et al. 2007a).

It is striking that didelphids have not been reported from the Pinturan ( 19-18 MYA; Cuitiño et al. 2016) or Santacrucian ( $\sim 18-15.6$ MYA, including the "Friasian" and "Colloncuran"; Cuitiño et al. 2016) faunas of southern South America, even though the latter in particular are extremely rich in fossil mammals (Vizcaíno et al. 2012). Instead, the dominant small-to-medium-bodied insectivorous-omnivorous mammals in these faunas are microbiotherians and paucituberculatans, with sparassodonts filling carnivorous niches (Marshall 1990; Bown and Fleagle 1993; Dumont et al. 2000; Croft 2007: appendix; Goin et al. 2010b; Abello et al. 2012; Chornogubsky and Kramarz 2012; Prevosti et al. 2012). Assuming that Didelphidae had indeed originated prior to the Pinturan, as suggested by our divergence dates, then the family was presumably restricted to lower latitudes at this time. However, the fossil record of mammals in northern South America is much poorer than that of the southern part of the continent (Goin et al. 2016), and so our knowledge of this key period in didelphid evolution is limited. Antoine et al. $(2016,2017)$ reported representatives of Didelphimorphia (sensu stricto) from the early Miocene (Colhuehuapian-Santacrucian; 20-17 MYA) CTA-63 site at Contamana, Peru. However, it is unclear whether these represent didelphids or not, with Antoine et al. (2017: 9) referring to them as being of "uncertain affinities." Nevertheless, our divergence dates suggest that they could potentially belong to the deepest lineages within Didelphidae.

Fossil didelphids from the middle Miocene (Laventan SALMA; 15.6-11.6 MYA) of Colombia and Peru include the oldest putative representatives of the extant genera Marmosa and Thylamys (Marshall 1976; Goin 1997a; Antoine et al. 2013, 2016, 2017). Based on our estimated divergence dates, the Marmosa lineage (= Marmosini) had probably originated by this time (16.2 MYA; 95\% HPD: 12.6-20.1 MYA), but the Thylamys lineage had not; in fact, our estimate for the split between Lestodelphys and Thylamys is in the latest Miocene or Pliocene (4.6 MYA; 95\% HPD: 3.0-6.6 MYA). If this date is broadly accurate, then the middle Miocene "Thylamys" species cannot belong to this genus. Among other putative didelphid material from the Laventan of Colombia, Goin (1997a: 194-195) briefly discussed a partial skull (GM KU-IV-1) that apparently represents a new didelphid genus, and tentatively referred to this taxon some additional isolated dental remains that show carnivorous adaptations (e.g., a strongly developed paracristid). In an earlier paper, Goin (1995) suggested that this taxon may be related to sparassocynins; however, the skull is still undescribed, and so its affinities remain uncertain.

Several fossil didelphids have been described from the lowest levels of the Ituzaingó Formation (= the "Mesopotamiense" or "Conglomerado Osífero") of Entre Rios Province, northeast Argentina (Ameghino 1898, 1899, 1900; Reig 1955, 1957b, 1958b; Marshall 1977c; Cione et al. 2000; Goin et al. 2013). They include two putative representatives of extant genera, namely Philander entrerianus and Chironectes sp. A third taxon, Zygolestes pararensis, has been proposed to be closely related to the extant Gracilinanus (Goin 1997b; Goin et al. 2000, 2013). However, none of these proposed relationships have been tested via formal phylogenetic analysis. The age of the "Mesopotamiense" has been controversial: several authors have suggested that it may represent a mixed fauna (Marshall 1977c; Goin 1997b; Cione et al. 2000), but this interpretation now appears to be incorrect (Goin et al. 2013). A radiometric date of 9.47 MYA from the underlying Paraná Formation provides a maximum age for this fauna (Pérez 2013), but there is debate (e.g., Cione et al. 2000; Brandoni 2013; Brunetto et al. 2013; Carrillo et al. 2014) as to whether it falls within the Chasicoan ( 10-8.7 MYA; Zarate et al. 2007) or Huayquerian SALMA. In either case, Philander entrerianus would seem to predate our estimate for the age of the Didelphis-Philander split (4.1 MYA; 95\% HPD: 3.3-5.4 MYA). However, we note here that Didelphis and Philander are craniodentally very similar (Voss and Jansa 2009), with the major difference being that the skull of Philander is somewhat smaller and less robust (Voss et al. 2018: 26); P. entrerianus is currently known only from a single lower molar (the holotype) and a partial right mandible (Goin et al. 2013), and so it cannot be assessed for cranial features.

The oldest putative Didelphis species, D. solimoensis from the Huayquerian Acre local fauna in western Brazil (Cozzuol et al. 2006; Antoine et al. 2017), also predates our estimate for the Didelphis-Philander split. However, like P. entrerianus, D. solimoensis is known from extremely limited remains, specifically a single partial right mandible (Cozzuol et al. 2006). Jansa et al. (2014: supporting information) considered the oldest fossil taxon to preserve diagnostic synapomorphies of Didelphis to be D. brachyodonta from the Chapadmalal Formation (Chapadmalalan SALMA; see below). At least 
three other didelphids are known from the Acre local fauna. Goin and de los Reyes (2011) described Lutreolina materdei, the oldest putative representative of this genus, based on a single lower molar; the Huayquerian age of $L$. materde $i$ is approximately congruent with our estimate for the age of the Lutreolina lineage (5.5 MYA; 95\% HPD: 4.1-7.4 MYA). Czaplewski (1996) described, but did not name, a further two taxa (a larger form resembling Hyperdidelphys and Thylamys, and a smaller form that might represent a marmosin) from the Acre local fauna, also based on isolated molars.

Turning now to the record from southern South America, Reig (1957a; see also Marshall 1976) identified a partial edentulous mandibular ramus from the Arroyo Chasicó Formation (type locality for the Chasicoan SALMA) in central Argentina as cf. Monodelphis or Thylatheridium. More recently, however, Croft (2007:303) referred to this specimen as an "indeterminate didelphid, probably a didelphine," while Engelman et al. (2016: 27) considered it to be "an indeterminate didelphoid." Given its incompleteness, relatively little can be said about this specimen. Goin (1995: 170) briefly mentioned other Chasicoan-aged remains from the Pampean Region that he concluded were referable to Sparassocynini, but these have not been mentioned in subsequent publications. Didelphids have otherwise not been described from the middle Miocene (= Laventan, Mayoan, and Chasicoan SALMAs) of southern South America. This may be due to a paucity of fossil-bearing sites (Engelman et al. 2016; Croft et al. 2018). However, Villafañe et al. (2008) reported the discovery of a rich fossil fauna (comprising $>600$ specimens) from the "El Petiso" site in Chubut Province, southern Argentina, which appears to be middle Miocene (perhaps Laventan or slightly earlier) in age; strikingly, although marsupialiforms (including insectivorous-omnivorous palaeothentids and carnivorous hathliacynids) are present at "El Petiso", didelphids appear to be absent (Villafañe et al. 2008; M. A. Abello, pers. comm.).

By contrast, multiple didelphid taxa have been reported from various Huayquerian sites in southern South America. They include two putative Thylamys species (T. pinei and T. zettii; Goin 1997c; Goin et al. 2000), although, like the Laventan "Thylamys," these taxa predate our estimate for the divergence between Thylamys and Lestodelphys (see above). Also present are the oldest known sparassocynin, Hesperocynus dolgopolae, and another extinct, carnivorously-adapted didelphid, Hyperdidelphys pattersoni (Goin and Pardiñas 1996; Forasiepi et al. 2009). A third carnivorous didelphid from the Huayqerian, "Thylatheridium" hudsoni, may also be a sparassocynin (Goin and Montalvo 1988; Forasiepi et al. 2009); if so, it is not closely related to the younger (Chapadmalan) Thylatheridium cristatum and T. pascuali, which appear to be very close to (if not within) Monodelphis (Reig 1958a; Goin and Rey 1997; Voss and Jansa 2009). Two other specimens from the Cerro Azul Formation - a partial skull originally referred to Hesperocynus dolgopolae (GHUNLPam 5119) and a right mandibular fragment identified as a probable sparassocynid (GHUNLPam 8334; Goin et al. 2000) - may represent additional carnivorously-adapted didelphid taxa (Forasiepi et al. 2009).

The appearance in the fossil record of several carnivorouslyadapted didelphid lineages during the Huayquerian seems to be part of a broader turnover in the South American mammal fauna, which appears to have occurred at some point between the Santacrucian-Laventan and Huayquerian (Engelman and Croft 2014; Goin et al. 2016). The precise timing and extent of this turnover is still unclear due to a comparative lack of fossil sites for this interval, and there may have been latitudinal differences in terms of faunal change (Engelman et al. 2016). However, among marsupialiforms, there is evidence for major declines in the insectivorous-omnivorous paucituberculatans (with only the family Caenolestidae surviving; Abello 2013: Fig. 8) and microbiotherians (possibly with only the lineage leading to the extant species Dromiciops gliroides persisting; Goin and Abello 2013: fig. 6), and also in the carnivorouslyadapted sparassodonts (from more than ten genera in the Santacrucian to five in the Huayquerian; Croft et al. 2018; Prevosti and Forasiepi 2018).

The cause(s) of this faunal turnover continue to be debated. One potential extrinsic driver is the major fall in global temperatures (the middle Miocene Climatic Transition, $\sim 14$ MYA) that followed the middle Miocene Climatic Optimum ( 15-17 MYA). Another is the spread of drier, more open habitats in South America, probably partly the result of the drop in temperatures and partly the result of Andean uplift (Strömberg 2011; Palazzesi and Barreda 2012; Strömberg et al. 2013; Engelman et al. 2016; Goin et al. 2016). This culminated in the grassland-dominated habitats characteristic of the "Age of the Southern Plains" ("“"Edad de las Planicies Australes"), which developed following the regression of the Paranean Sea, 10 MYA (Pascual and Bondesio 1982; Pascual et al. 1996; Ortiz Jaureguizar 1998; Ortiz-Jaureguizar and Cladera 2006). Potential intrinsic drivers, meanwhile, include competition - for example, between paucituberculatans and microbiotherians and insectivorous-omnivorous didelphids, and between sparassodonts and carnivorous didelphids - , the arrival of novel predators (such as pitvipers and procyonid carnivorans) from North America, or other, unspecified biotic interactions (Prevosti et al. 2013; Engelman and Croft 2014; Jansa et al. 2014; Zimicz 2014; Engelman et al. 2016; López-Aguirre et al. 2017; Prevosti and Forasiepi 2018). Confidently resolving the relative importance of these different factors to the changes in marsupialiform diversity observed in South America during the Miocene will require improvements in the fossil 
record, refinements in the dating of fossil sites, and methods that can specifically compare the relative importance of extrinsic and intrinsic drivers (see Silvestro et al. 2015).

Focusing specifically on carnivorous marsupialiforms, a key question has been whether or not the appearance of carnivorously-adapted didelphids in the Huayquerian is related to a decline in sparassodonts prior to this (e.g., Patterson and Pascual 1968; Marshall 1977b, 1978; Goin 1989, 1995; Alberdi et al. 1995; Pascual et al. 1996; Ortiz Jaureguizar 1998, 2001; Forasiepi et al. 2007; Prevosti et al. 2013; Engelman and Croft 2014; Zimicz 2014; Engelman et al. 2016; López-Aguirre et al. 2017; Prevosti and Forasiepi 2018). Some authors have argued that carnivorously-adapted didelphids may have replaced hathliacynids ecologically (e.g., Patterson and Pascual 1968; Marshall 1977b, 1978; Goin 1989; Ortiz Jaureguizar 1998, 2001; Forasiepi et al. 2007). However, Zimicz (2014) and Croft et al. (2018) both concluded that small sparassodonts (e.g., the smaller hathliacynids) are unlikely to have represented ecological competitors of carnivorously-adapted didelphids (including sparassocynins), based principally on the results of morphometric studies of tooth shape in which sparassodonts and didelphids occupy largely non-overlapping morphospaces (see also Prevosti et al. 2013; Maga and Beck 2017: Fig. 36). However, it is likely that these results are strongly influenced by phylogenetic factors, as we discuss in detail here.

Zimicz (2014) found that carnivorously-adapted didelphids and hathliacynids could be distinguished based on Relative Grinding Area (RGA; = square root of area of talonid/total length of molar), which is consistently larger in didelphids, and Relative Blade Length (RBL; = length of trigonid/total length of molar), which is consistently larger in hathliacynids. However, Zimicz (2014) calculated both of these metrics based on the last lower molar (m4) only, and the m4 of hathliacynids and other sparassodonts is particularly specialized, with a greatly reduced talonid. We agree with Croft et al. (2018: supplementary) that "measuring RGA in sparassodonts using only $\mathrm{m} 4$ likely underestimates the total grinding area of the tooth row in many cases." The highly reduced $\mathrm{m} 4$ talonid in hathliacynids also results in very large values for RBL. When RGA is calculated based on m1-4 combined (Croft et al. 2018: character 16), values for didelphids (state 4, $\mathrm{RGA}=0.25-0.43$ ) are broadly similar to those for hathliacynids (states 4 and $5, \mathrm{RGA}=0.167-0.43$ ).

The major difference between carnivorously-adapted didelphids and hathliacynids in the analysis of Croft et al. (2018) concerns character 12, namely the "angle of the lower carnassial trigonid cusps in occlusal view," which was again scored based on m4; the didelphids (including Sparassocynus) have an angle of $40-80^{\circ}$ (state 3 ), whereas most sparassodonts (including all hathliacynids) entirely lack a metaconid on $\mathrm{m} 4$, and so were assigned a separate state based on their non- comparable morphology (state 6). Loss of the metaconid on m1-4 appears to be a synapomorphy of Hathliacynidae+ Borhyaenoidea within Sparassodonta, in which case it must have been lost >40 MYA (Forasiepi 2009: fig. 56). Reduction of the metaconid is a characteristic carnivorous adaptation, but total loss of this cusp on all molars, as in Hathliacynidae+ Borhyaenoidea, is usually only seen in specialized hypercarnivorous forms (Muizon and Lange-Badré 1997; Solé and Ladevèze 2017). However, hathliacynids otherwise show features that suggest that they were less carnivorouslyspecialized than borhyaenoids, such as less carnassialized molars with larger RGA (Prevosti et al. 2012, 2013; Zimicz 2014; Croft et al. 2018: characters 8, 9 and 16; Prevosti and Forasiepi 2018), and comparatively longer and more slender mandibles (Echarri et al. 2017). The absence of the metaconid in hathliacynids may therefore simply reflect a phylogenetic constraint inherited from hypercarnivorous ancestors, and not necessarily an indicator of a more carnivorous diet than that of the carnivorously-adapted didelphids. Indeed, Solé and Ladevèze (2017) observed that in carnivorous mammals the metaconid is only rarely reacquired after having been lost (although we note that the metaconid was apparently reacquired on $\mathrm{m} 2-4$ by at least two borhyaenoid lineages; Forasiepi et al. 2014: online supplementary material fig. 5). Echarri et al.'s (2017) analysis of mandible shape suggested that most hathylacynids were probably omnivores or mesocarnivores, perhaps ecologically similar to extant Dasyurus spp., in contrast to analyses based on tooth shape, which indicate that hathliacynids were probably all hypercarnivores (Prevosti et al. 2012, 2013; Zimicz 2014; Croft et al. 2018; Prevosti and Forasiepi 2018).

Of the remaining characters used by Croft et al. (2018), all of the states found in hathliacynids were also observed in at least one didelphid taxon, and vice versa. Based on their similar body size $(<1.5 \mathrm{~kg})$ and molars with a similar degree of "carnassialization," we therefore consider it plausible that the smallest hathliacynids (Notictis, Perathereutes, and Pseudonotictis) and the most carnivorously-adapted didelphids (sparassocynins, Hyperdidelphys, Lutreolina, and Thylatheridium) represent broad ecological equivalents, contra Zimicz (2014) and Croft et al. (2018) but congruent with the findings of Echarri et al. (2017). Even if this hypothesis is correct, however, this does not necessarily indicate that the decline and ultimate extinction of hathliacynids was due to direct competition from didelphids. Carnivorously-adapted didelphids do not appear to have become widespread until the Huayquerian, by which time sparassodont diversity appears to have already declined (Prevosti et al. 2013; Zimicz 2014; Croft et al. 2018: fig. 2a; Prevosti and Forasiepi 2018), although this may be at least partly the result of sampling biases, in particular the excellent record of sparassodonts in the Santa Cruz Formation and the relative lack of fossil-bearing sites from the middle Miocene (see above). Furthermore, small-bodied 
( $<3 \mathrm{~kg}$ ) hathliacynids (Borhyaenidium, Notocynus, Notictis) coexisted with carnivorously-adapted didelphids during the Huayquerian and Chapadmalan, a timespan of several million years (Prevosti et al. 2013; Zimicz 2014; Prevosti and Forasiepi 2018).

Based on an analysis of diversification of extant didelphids, Jansa et al. (2014) found evidence of a probable massextinction event affecting multiple didelphid lineages during the early-to-middle Miocene. We found evidence of a similar pattern when only extant didelphid lineages are considered, namely a period of low diversification 15.0-10.3 MYA (95\% HPD: 18.9-7.9 MYA; Figs. 12 and 14). Jansa et al. (2014) identified two possible causes for this: the existence of the Pebas lacustrine system in western Amazonia 23-8 MYA (reaching its maximum extent 10-14 MYA), or the arrival of new predators (including procyonid carnivorans and pitvipers) from North America, which may have begun in the middle Miocene (Jansa et al. 2014: 692). Jansa et al. (2014: 691) specifically ruled out Miocene climate change and tectonic activity (e.g., Andean uplift) as potential explanations, because molecular phylogenies of a range of other Neotropical organisms do not indicate a Miocene extinction event (Ramirez et al. 2010; Derryberry et al. 2011; Eiserhardt et al. 2011). However, diversification rates that are inferred from extant lineages only can often be misleading (Rabosky 2010, 2016; Marshall 2017; Mitchell et al. 2018), and (as discussed above) the mammalian fossil record of South America clearly does suggest a major faunal turnover between the Santacrucian and the Huayquerian (Pascual et al. 1996; Engelman and Croft 2014; Engelman et al. 2016; Goin et al. 2016). In any case, our phylogenetic results suggest an alternative interpretation, showing the importance of incorporating evidence from the fossil record into studies of diversification.

Specifically, our estimate for the origin of Sparassocynini (10.5 MYA; 95\% HPD: 7.2-16.0 MYA) falls within the period of zero diversification observed when only extant didelphid lineages are considered. Although we have not tested its phylogenetic affinities here, Hyperdidelphys represents another carnivorous didelphid lineage that does not appear to be closely related to Sparassocynini (Goin and Pardiñas 1996; Voss and Jansa 2009), and which must have originated prior to the Huayquerian, i.e., potentially within the interval of zero diversification observed in extant didelphids. Thus, sparassocynins and Hyperdidelphys may represent two "missing" didelphid lineages. Other Huayquerian-aged didelphid remains represent possible additional carnivorously-adapted lineages that similarly may have originated within this period (Goin et al. 2000; Forasiepi et al. 2009). Sparassocynins and Hyperdidelphys both survived into the Pliocene, and so their extinction cannot be explained by any events that took place in the Miocene. Furthermore, all known sparassocynin and Hyperdidelphys fossils are known from outside Amazonia, suggesting that the spread of the
Pebas lake system, and concomitant loss of terrestrial habitat in this region, is unlikely to have affected their diversification. Thus, neither of Jansa et al.'s (2014) proposed explanations for the apparent "pause" in diversification seen in extant didelphids plausibly accounts for the extinction of sparassocynins and Hyperdidelphys.

Instead, we propose a revised scenario. Sparassocynins and Hyperdidelphys show greater dental specializations for carnivory than all living didelphids except Lutreolina (see Reig and Simpson 1972; Voss and Jansa 2003: Fig. 12), and we suggest that these two carnivorously-adapted lineages (and possibly others) originated during the middle-to-late Miocene, perhaps in connection with the decline in sparassodont diversity seen at this time. As already noted, sparassocynins and Hyperdidelphys also exhibit hypotympanic sinuses that are larger than those of all extant didelphids. Inflation of the middle ear cavity results in improved low-frequency hearing, and in small-to-medium-sized mammals is usually associated with more open habitats (see Mason 2016a, 2016b and references therein). Pollen evidence suggests that open-habitat ecosystems developed in southern South America within the last $10 \mathrm{Ma}$, i.e., from the Huayquerian onwards (Palazzesi and Barreda 2012), which coincides with the appearance in the fossil record of these didelphid lineages with comparatively inflated hypotympanic sinuses. These carnivorous, openhabitat-adapted lineages then went extinct at some point after the Chapadmalalan, possibly due to competition from placental mustelids, which first appear in the South American fossil record during the Vorohuean subage of the Marplatan $(\sim 2.9$ 2.7 MYA; Prevosti and Pardiñas 2009; Prevosti et al. 2013; Prevosti and Forasiepi 2018). Another possible driver of their extinction is a major reduction in the diversity of small, burrowing caviomorph rodents (potential prey items for carnivorous didelphids) observed after the Chapadmalalan (Ortiz Jaureguizar et al. 1995, 2012). This post-Chapadmalalan reduction in caviomorph diversity is indicated both by changes in the taxonomic composition of fossil small mammal assemblages (Ortiz Jaureguizar et al. 2012), and by a marked reduction in the frequency of paleoburrows (many of which were undoubtedly made by small caviomorphs; Genise 1989; Cenizo et al. 2015) between the Chapadmalalan and Barrancalobian (Ortiz Jaureguizar et al. 1995). This reduction in caviomorph diversity may have been due to the development of increasingly cool and arid conditions (Ortiz Jaureguizar et al. 1995), the arrival of predatory mustelids, competition from sigmodontine rodents, or a combination of these factors. Whatever the precise cause, we propose that the middle-to-late Miocene period of low diversification observed in extant didelphids is not due to a extinction event at this time (as was proposed by Jansa et al. 2014), but rather due to the later (Pliocene) extinction of carnivorous, open-habitatadapted lineages that originated in middle-to-late Miocene. 
As noted by Engelman et al. (2016: 25-27), there appear to be striking parallels between the evolution of South American and Australian marsupial carnivores during the Neogene. On both landmasses, the middle-to-late Miocene saw a decline in the previously dominant carnivorous clade (Sparassodonta in South America, Thylacinidae in Australia), with this decline approximately coinciding with the diversification of carnivorously-adapted members of a different clade (sparassocynins, Hyperdidelphys, and possibly other didelphid lineages in South America, dasyurids in Australia). In both cases, this coincides with evidence for the development of more open habitats, and the clades showing increased diversification exhibit auditory adaptations suitable for such environments (Wroe 1996; Black et al. 2012; Engelman et al. 2016; Kealy and Beck 2017). In South America, most of the carnivorously-adapted didelphids went extinct after the Chapadmalalan, which we suggest may have been due to competition from placental invaders, such as mustelids (as previously proposed by Marshall 1977b, 1978; Goin 1989; Ortiz Jaureguizar 2001; Prevosti et al. 2013: 13). In Australia, meanwhile, dasyurids have suffered recent extreme range reductions, with many species now critically endangered, due (at least in part) to the introduction of placental carnivorans, namely dogs, foxes, and cats (Jones et al. 2003; Wilson et al. 2003).

Acknowledgements RMDB's research on this project has been funded by the National Science Foundation (grant DEB-0743039, in collaboration with Rob Voss at the AMNH), Australian Research Council (via Discovery Early Career Researcher Award DE120100957), and a Santander Travel Award via the University of Salford. We are grateful to the staff of the Museo Municipal de Ciencias Naturales "Lorenzo Scaglia" in Mar del Plata for their assistance and access to their collection, particularly Fernando Scaglia and María Victoria Sarasa. We thank Alejandra Abello, Darin Croft, Russell Engelman, Analía Forasiepi, Ross MacPhee, and Rob Voss for discussion, and two anonymous reviewers, and the editor, John Wible, for their detailed and constructive comments. For their warm hospitality and friendship while visiting Argentina, RMDB thanks Andres Giallombardo and the Duca family.

Open Access This article is distributed under the terms of the Creative Commons Attribution 4.0 International License (http:// creativecommons.org/licenses/by/4.0/), which permits unrestricted use, distribution, and reproduction in any medium, provided you give appropriate credit to the original author(s) and the source, provide a link to the Creative Commons license, and indicate if changes were made.

\section{References}

Abello MA (2013) Analysis of dental homologies and phylogeny of Paucituberculata (Mammalia: Marsupialia). Biol J Linn Soc 109: 441-465. https://doi.org/10.1111/Bij.12048

Abello MA, De Los Reyes M, Candela AM, Pujos F, Voglino D, Quispe BM (2015) Description of a new species of Sparassocynus (Marsupialia: Didelphoidea: Sparassocynidae) from the late
Miocene of Jujuy (Argentina) and taxonomic review of Sparassocynus heterotopicus from the Pliocene of Bolivia. Zootaxa 3937:147-160

Abello MA, Ortiz-Jaureguizar E, Candela AM (2012) Paleoecology of the Paucituberculata and Microbiotheria (Mammalia, Marsupialia) from the late early Miocene of Patagonia. In: Vizcaíno SF, Kay RF, Bargo MS (eds) Early Miocene Paleobiology in Patagonia: HighLatitude Paleocommunities of the Santa Cruz Formation. Cambridge University Press, Cambridge, pp 156-172

Alberdi MT, Ortiz Jaureguizar E, Prado JL (1995) Evolución de las comunidades de mamíferos del Cenozoico superior de la Provincia de Buenos Aires, Argentina. Rev Esp Paleontol 10:30-36

Ameghino F (1898) Sinopsis geológico-paleontológica de la República Argentina. In: Segundo Censo de la República Argentina. Buenos Aires, pp 112-255

Ameghino F (1899) Sinopsis geológico-paleontológica de la República Argentina: Suplemento (Adiciones y correcciones). Imprenta La Libertad, La Plata

Ameghino F (1900) La presencia de mamíferos diprotodontes en los depósitos terciarios de Paraná. An Soc Cient Argent 49:235-240

Ameghino F (1908) Las formaciones sedimentarias de la región litoral de Mar del Plata y Chapadmalán Anales Museo Nacional Buenos Aires 3:343-428

Antoine P-O, Abello MA, Adnet S, Altamirano Sierra AJ, Baby P, Billet G, Boivin M, Calderón Y, Candela A, Chabain J, Corfu F, Croft DA, Ganerød M, Jaramillo C, Klaus S, Marivaux L, Navarrete RE, Orliac MJ, Parra F, Pérez ME, Pujos F, Rage J-C, Ravel A, Robinet C, Roddaz M, Tejada-Lara JV, Vélez-Juarbe J, Wesselingh FP, SalasGismondi R (2016) A 60-million-year Cenozoic history of western Amazonian ecosystems in Contamana, eastern Peru. Gondwana Res 31:30-59. https://doi.org/10.1016/j.gr.2015.11.001

Antoine P-O, Marivaux L, Croft DA, Billet G, Ganerod M, Jaramillo C, Martin T, Orliac MJ, Tejada J, Altamirano AJ, Duranthon F, Fanjat G, Rousse S, Gismondi RS (2011) Middle Eocene rodents from Peruvian Amazonia reveal the pattern and timing of caviomorph origins and biogeography. Proc R Soc B: Biol Sci 279:1319-1326. https://doi.org/10. 1098/rspb.2011.1732

Antoine P-O, Roddaz M, Brichau S, Tejada-Lara J, Salas-Gismondi R, Altamirano A, Louterbach M, Lambs L, Otto T, Brusset S (2013) Middle Miocene vertebrates from the Amazonian Madre de Dios Subandean Zone, Peru. J So Am Earth Sci 42:91-102 https://doi. org/10.1016/j.jsames.2012.07.008

Antoine P-O, Salas-Gismondi R, Pujos F, Ganerød M, Marivaux L (2017) Western Amazonia as a hotspot of mammalian biodiversity throughout the Cenozoic. J Mammal Evol 24:5-17

Aplin KP (1987) Basicranial anatomy of the early Miocene diprotodontian Wynyardia bassiana (Marsupialia: Wynyardiidae) and its implications for wynyardiid phylogeny and classification. In: Archer M (ed) Possums and Opossums: Studies in Evolution. Surrey Beatty \& Sons, Sydney, pp 369-391

Aplin KP (1990) Basicranial regions of diprotodontian marsupials: anatomy, ontogeny and phylogeny. Unpublished Ph. D. Dissertation, University of New South Wales, School of Biological Sciences, Sydney

Archer M (1976a) The basicranial region of marsupicarnivores (Marsupialia), inter-relationships of carnivorous marsupials, and affinities of the insectivorous marsupial peramelids. Zool J Linn Soc 59:217-322

Archer M (1976b) The dasyurid dentition and its relationships to that of didelphids, thylacinids, borhyaenids (Marsupicarnivora) and peramelids (Peramelina : Marsupialia). AustJ Zool Suppl Ser S39: $1-34$

Archer M (1982) A review of Miocene thylacinids (Thylacinidae, Marsupialia), the phylogenetic position of the Thylacinidae and 
the problem of apriorisms in character analysis. In: Archer M (ed) Carnivorous Marsupials. Royal Zoological Society of New South Wales, Sydney, pp 445-476

Barba-Montoya J, Dos Reis M, Yang Z (2017) Comparison of different strategies for using fossil calibrations to generate the time prior in Bayesian molecular clock dating. Mol Phylogenet Evol 114:386400. https://doi.org/10.1016/j.ympev.2017.07.005

Beaulieu JM, O'Meara BC, Crane P, Donoghue MJ (2015) Heterogeneous rates of molecular evolution and diversification could explain the Triassic age estimate for angiosperms. Syst Biol 64:869-878. https://doi.org/10.1093/sysbio/syv027

Beck RMD (in press) Current understanding of the phylogeny of Metatheria: a review. In: Goin FJ, Forasiepi AM (eds) New World Marsupials and Their Extinct Relatives: 100 Million Years of Evolution. Springer, Berlin

Beck RMD, Lee MSY (2014) Ancient dates or accelerated rates? Morphological clocks and the antiquity of placental mammals. Proc R Soc B: Biol Sci 281:20141278. https://doi.org/10.1098/ rspb.2014.1278

Beck RMD, Travouillon KJ, Aplin KP, Godthelp H, Archer M (2014) The osteology and systematics of the enigmatic Australian oligoMiocene metatherian Yalkaparidon (Yalkaparidontidae; Yalkaparidontia; ?Australidelphia; Marsupialia). J Mammal Evol 21:127-172

Beck RM, Voss RS, Jansa SA (2012) A comprehensive genuslevel phylogeny of living and extinct marsupials based on craniodental and molecular data. J Vertebr Paleontol Program and Abstracts 2012:62A

Black KH, Archer M, Hand SJ, Godthelp H (2012) The rise of Australian marsupials: a synopsis of biostratigraphic, phylogenetic, palaeoecologic and palaeobiogeographic understanding. In: Talent JA (ed) Earth and Life: Global Biodiversity, Extinction Intervals and Biogeographic Perturbations Through Time. Springer Verlag, Dordrecht, pp 983-1078

Boivin M, Marivaux L, Orliac MJ, Pujos F, Salas-Gismondi R, TejadaLara JV, Antoine P-O (2017) Late middle Eocene caviomorph rodents from Contamana, Peruvian Amazonia. Palaeontol Electron 20.1.19A:1-1.19A50

Bond M, Tejedor MF, Campbell KE Jr, Chornogubsky L, Novo N, Goin F (2015) Eocene primates of South America and the African origins of New World monkeys. Nature 520:538-541. https://doi.org/10. 1038/nature 14120

Bown TM, Fleagle JG (1993) Systematics, biostratigraphy, and dental evolution of the Palaeothentidae, later Oligocene to early-middle Miocene (Deseadan-Santacrucian) caenolestoid marsupials of South America. Paleontol Soc Mem 29:1-76

Brandoni D (2013) Los mamíferos continentales del "Mesopotamiense" (Mioceno tardío) de Entre Ríos, Argentina. Diversidad, edad y paleobiogeografía. In: Brandoni D, Noriega JI (eds) El Neógeno de la Mesopotamia argentina. Asociación Paleontológica Argentina, Publicación Especial. Asociación Paleontológica Argentina, Buenos Aires, pp 179-191

Brunetto E, Noriega JI, Brandoni D (2013) Sedimentología, estratigrafía y edad de la Formación Ituzaingó en la Provincia de Entre Ríos, Argentina. In: Brandoni D, Noriega JI (eds) El Neógeno de la Mesopotamia argentina. Asociación Paleontológica Argentina, Publicación Especial. Asociación Paleontológica Argentina, Buenos Aires, pp 13-27

Carrillo JD, Forasiepi A, Jaramillo C, Sanchez-Villagra MR (2014) Neotropical mammal diversity and the Great American Biotic Interchange: spatial and temporal variation in South America's fossil record. Front Genet 5:1-11. https://doi.org/10.3389/fgene.2014. 00451

Cenizo M, Soibelzon E, Magnussen Saffer M (2015) Mammalian predator-prey relationships and reoccupation of burrows in the Pliocene of the Pampean Region (Argentina): new ichnological and taphonomic evidence. Hist Biol 28:1026-1040. https://doi.org/ 10.1080/08912963.2015.1089868

Chemisquy MA (2015) Peramorphic males and extreme sexual dimorphism in Monodelphis dimidiata (Didelphidae). Zoomorphology 134:587-599. https://doi.org/10.1007/s00435-015-0274-7

Chornogubsky L, Kramarz AG (2012) Nuevos hallazgos de Microbiotheriidae (Mammalia, Marsupialia) en la Formación Pinturas (Mioceno Temprano, Argentina). Ameghiniana 49: $442-450$

Cione AL, Azpelicueta MM, Bond M, Carlini AA, Casciotta JR, Cozzuol MA, de la Fuente M, Gasparini Z, Goin FJ, Noriega JI, Scillato Yané GJ, Soibelzon L, Tonni EP, Verzi D, Vucetich MG (2000) Miocene vertebrates from Entre Ríos province, eastern Argentina. In: Aceñolaza FG, Herbst R (eds) El Neógeno de Argentina. Serie Correlación Geológica, vol 14, pp 191-237

Cione AL, Gasparini GM, Soibelzon E, Soibelzon LH, Tonni EP (2015) The Great American Biotic Interchange: A South American Perspective. Springer, Dordrecht

Cione AL, Tonni EP, Bargo MS, Bond M, Candela AM, Carlini AA, Deschamps CM, Dozo MT, Esteban G, Goin FJ, Montalvo CI, Nasif N, Noriega JI, Ortiz Jaureguizar E, Pascual R, Prado JL, Reguero MA, Scillato-Yané GJ, Soibelzon L, Verzi DH, Vieytes C, Vizcaíno F, Vucetich MG (2007) Mamíferos continentales del Mioceno tardío a la actualidad en la Argentina: cincuenta años de estudios. Ameghiniana Publicación Especial 11:257-278

Clark CT, Smith KK (1993) Cranial osteogenesis in Monodelphis domestica (Didelphidae) and Macropus eugenii (Macropodidae). J Morphol 215:119-149

Condamine FL, Nagalingum NS, Marshall CR, Morlon H (2015) Origin and diversification of living cycads: a cautionary tale on the impact of the branching process prior in Bayesian molecular dating. BMC Evol Biol 15:65. https://doi.org/10. 1186/s12862-015-0347-8

Cozzuol MA, Goin F, De Los Reyes M, Ranzi A (2006) The oldest species of Didelphis (Mammalia, Marsupialia, Didelphidae), from the late Miocene of Amazonia. J Mammal 87:663-667

Croft DA (2007) The middle Miocene (Laventan) Quebrada Honda Fauna, southern Bolivia and a description of its notoungulates. Palaeontology 50:277-303

Croft DA, Engelman RK, Dolgushina T, Wesley G (2018) Diversity and disparity of sparassodonts (Metatheria) reveal non-analogue nature of ancient South American mammalian carnivore guilds. Proc R Soc B: Biol Sci 285:20172012. https://doi.org/10.1098/rspb.2017.2012

Cuitiño, JI Fernicola JC, Kohn MJ, Trayler R, Naipauer M, Bargo MS, Kay RF, Vizcaíno SF (2016) U-Pb geochronology of the Santa Cruz Formation (early Miocene) at the Río Bote and Río Santa Cruz (southernmost Patagonia, Argentina): implications for the correlation of fossil vertebrate localities. J So Am Earth Sci 70:198-210. https://doi.org/10.1016/j.jsames.2016.05.007

Czaplewski NJ (1996) Opossums (Didelphidae) and bats (Noctilionidae and Molossidae) from the late Miocene of the Amazon Basin. J Mammal 77:84-94. https://doi.org/10.2307/1382711

Derryberry EP, Claramunt S, Derryberry G, Chesser RT, Cracraft J, Aleixo A, Perez-Eman J, Remsen JV, Brumfield RT (2011) Lineage diversification and morphological evolution in a largescale continental radiation: the Neotropical ovenbirds and woodcreepers (Aves: Furnariidae). Evolution 65:2973-2986. https://doi.org/10.1111/j.1558-5646.2011.01374.x

Deschamps CM, Vucetich MG, Montalvo CI, Zárate MA (2013) Capybaras (Rodentia, Hydrochoeridae, Hydrochoerinae) and their bearing in the calibration of the late Miocene-Pliocene sequences of South America. J So Am Earth Sci 48:145-158. https://doi.org/10. 1016/j.jsames.2013.09.007

Dias CAR, Perini FA (2018) Biogeography and early emergence of the genus Didelphis (Didelphimorphia, Mammalia). Zool Scr 47:645-654 
Díaz-Nieto JF, Jansa SA, Voss RS (2016) Phylogenetic relationships of Chacodelphys (Marsupialia: Didelphidae: Didelphinae) based on “ancient” DNA sequences. J Mammal 97:394-404. https://doi.org/ 10.1093/jmammal/gyv197

Duchen P, Leuenberger C, Szilagyi SM, Harmon L, Eastman J, Schweizer M, Wegmann D (2017) Inference of evolutionary jumps in large phylogenies using Lévy processes. Syst Biol 66:950-963. https://doi.org/10.1093/sysbio/syx028

Dumont ER, Strait SG, Friscia AR (2000) Abderitid marsupials from the Miocene of Patagonia: an assessment of form, function, and evolution. J Paleontol 74:1161-1172

Dunn RE, Madden RH, Kohn MJ, Schmitz MD, Stromberg CAE, Carlini AA, Re GH, Crowley J (2012) A new chronology for middle Eocene-early Miocene South American Land Mammal Ages. Geol Soc Am Bull 125:539-555. https://doi.org/10.1130/b30660.1

Echarri S, Ercoli MD, Chemisquy MA, Turazzini G, Prevosti FJ (2017) Mandible morphology and diet of the South American extinct metatherian predators (Mammalia, Metatheria, Sparassodonta). Earth Environ Sci Trans R Soc Edinb 106:277-288. https://doi. org/10.1017/s1755691016000190

Eiserhardt WL, Pintaud JC, Asmussen-Lange C, Hahn WJ, Bernal R, Balslev H, Borchsenius F (2011) Phylogeny and divergence times of Bactridinae (Arecaceae, Palmae) based on plastid and nuclear DNA sequences. Taxon 60:485-498

Engelman RK, Anaya F, Croft DA (2016) New palaeothentid marsupials (Paucituberculata) from the middle Miocene of Quebrada Honda, Bolivia, and their implications for the palaeoecology, decline and extinction of the Palaeothentoidea. J Syst Palaeontol 15:787-820. https://doi.org/10.1080/14772019.2016.1240112

Engelman RK, Croft DA (2014) A new species of small-bodied sparassodont (Mammalia, Metatheria) from the middle Miocene locality of Quebrada Honda, Bolivia. J Vertebr Paleontol 34:672-688. https://doi.org/10.1080/02724634.2013.827118

Flores DA (2009) Phylogenetic analyses of postcranial skeletal morphology in didelphid marsupials. Bull Am Mus Nat Hist 320:1-81

Flores DA, Abdala F, Giannini N (2010) Cranial ontogeny of Caluromys philander (Didelphidae: Caluromyinae): a qualitative and quantitative approach. J Mammal 91:539-550. https://doi.org/10.1644/09mamm-a-291.1

Forasiepi AM (2009) Osteology of Arctodictis sinclairi (Mammalia, Metatheria, Sparassodonta) and phylogeny of Cenozoic metatherian carnivores from South America. Monogr Mus Argent Cienc Nat 6: $1-174$

Forasiepi AM, Goin F, Martinelli AG (2009) Contribution to the knowledge of the Sparassocynidae (Mammalia, Metatheria, Didelphoidea), with comments on the age of the Aisol Formation (Neogene), Mendoza Province, Argentina. J Vertebr Paleontol 29: $1252-1263$

Forasiepi AM, Babot MJ, Zimicz N (2014) Australohyaena antiqua (Mammalia, Metatheria, Sparassodonta), a large predator from the late Oligocene of Patagonia. J Syst Palaeontol 13:503-525

Forasiepi AM, Martinelli AG, Goin FJ (2007) Revisión taxonómica de Parahyaenodon argentinus Ameghino y sus implicancias en el conocimiento de los grandes mamíferos carnívoros del MioPlioceno de América del Sur. Ameghiniana 44:143-159

Forasiepi AM, Martinelli AG, de la Fuente MS, Dieguez S, Bond M (2011) Paleontology and stratigraphy of the Aisol Formation (Neogene), San Rafael, Mendoza. In: Salfity J, Marquillas RA (eds) Cenozoic Geology of the Central Andes of Argentina. SCS Publisher, Salta, pp 135-154

Gardner AL (ed) (2008) Mammals of South America. Vol. 1. Marsupials, Xenarthrans, Shrews, and Bats. University of Chicago Press, Chicago

Garrido AC, Turazzini GF, Bond M, Aguirrezabala G, Forasiepi AM (2014) Estratigrafía, vertebrados fósiles y evolución tectosedimentaria de los depósitos neógenos del Bloque de San
Rafael (Mioceno-Plioceno), Mendoza, Argentina. Acta Geol Lilloana 26:133-164

Genise JF (1989) Las cuevas con Actenomys (Rodentia, Octodontidae) de la Formación Chapadmalal (Plioceno superior) de Mar del Plata y Miramar (provincia de Buenos Aires). Ameghiniana 26:33-42

Giarla TC, Jansa SA (2014) The role of physical geography and habitat type in shaping the biogeographical history of a recent radiation of Neotropical marsupials (Thylamys: Didelphidae). J Biogeogr 41: 1547-1558. https://doi.org/10.1111/jbi. 12320

Godthelp H, Wroe S, Archer M (1999) A new marsupial from the early Eocene Tingamarra Local Fauna of Murgon, southeastern Queensland: A prototypical Australian marsupial? J Mammal Evol 6:289-313

Goin FJ (1989) Late Cenozoic South American marsupial and placental carnivores: changes in predator-prey evolution. 5th International Theriological Congress (Rome, Italy), Abstracts 1:271-272

Goin FJ (1991) Los Didelphoidea (Mammalia, Marsupialia) del Cenozoico tardío de la región Pampeana. Unpublished $\mathrm{PhD}$, Universidad Nacional de La Plata

Goin FJ (1995) Los marsupiales. In: Alberdi MT, Leone G, Tonni EP (eds) Evolución Biológica y Climática de la Región Pampeana Durante los Últimos Cinco Millones de Años. Museo Nacional de Ciencias Naturales, Madrid, pp 165-179

Goin FJ (1997a) New clues for understanding Neogene marsupial radiations. In: Kay RF, Madden RH, Cifelli RL, Flynn JJ (eds) Vertebrate Paleontology in the Neotropics: the Miocene Fauna of La Venta, Colombia. Smithsonian Institution Press, Washington, pp 187-206

Goin FJ (1997b) Sobre la edad y afinidades de Zygolestes paranensis Ameghino, 1898 (Marsupialia, Didelphidae, Marmosinae). Neotropica 43:15-19

Goin FJ (1997c) Thylamys zettii, nueva especie de marmosino (Marsupialia, Didelphidae) del Cenozoico de la región pampeana. Ameghiniana 34:481-484

Goin FJ, Abello MA (2013) Los Metatheria sudamericanos de comienzos del Neógeno (Mioceno temprano, edad mamífero Colhuehuapense). Parte 2: Microbiotheria y Polydolopimorphia. Ameghiniana 50:51-78

Goin F, Abello A, Bellosi E, Kay R, Madden R, Carlini A (2007a) Los Metatheria sudamericanos de comienzos del Neógeno (Mioceno Temprano, Edad-mamífero Colhuehuapense). Parte I: Introducción, Didelphimorphia y Sparassodonta. Ameghiniana 44:29-71

Goin FJ, Abello MA, Chornogubsky L (2010a) Middle Tertiary marsupials from Central Patagonia (early Oligocene of Gran Barranca): understanding South America's Grande Coupure. In: Madden RH, Carlini AA, Vucetich MG, Kay RF (eds) The Paleontology of Gran Barranca: Evolution and Environmental Change Through the Middle Cenozoic of Patagonia. Cambridge University Press, Cambridge, pp 71-107

Goin FJ, Candela AM (2004) New Paleogene marsupials from the Amazon Basin of eastern Peru. In: Campbell KE Jr (ed) The Paleogene Mammalian Fauna of Santa Rosa, Amazonian Peru. Nat Hist Mus Los Angeles County Sci Ser 40:15-60

Goin FJ, de los Reyes M (2011) Contribución al conocimiento de los representantes extintos de Lutreolina Thomas, 1910 (Mammalia, Marsupialia, Didelphidae). Historia Natural 1:15-25

Goin FJ, Gelfo JN, Chornogubsky L, Woodburne MO, Martin T (2012) Origins, radiations, and distribution of South American mammals: From greenhouse to icehouse worlds. In: Patterson BD, Costa LP (eds) Bones, Clones, and Biomes: an 80-Million Year History of Modern Neotropical Mammals. University of Chicago Press, Chicago, pp 20-50

Goin FJ, Montalvo CI (1988) Revisión sistemática y reconocimiento de una nueva especie del género Thylatheridium Reig (Marsupialia, Didelphidae). Ameghiniana 25:161-167

Goin FJ, Montalvo C, Visconti G (2000) Los marsupiales (Mammalia) del Mioceno superior de la Formacion Cerro Azul (Provincia de La Pampa, Argentina). Revista Española de Geología 56:101-126 
Goin FJ, Noriega JI, de los Reyes M (2013) Los Metatheria (Mammalia) del "Mesopotamiense" (Mioceno Tardío) de la Provincia de Entre Ríos, Argentina, y una reconsideración de Philander entrerianus (Ameghino, 1899). In: Brandoni D, Noriega JI (eds) El Neógeno de la Mesopotamia argentina. Asociación Paleontológica Argentina, Publicación Especial. Asociación Paleontológica Argentina, Buenos Aires, pp 109-117

Goin FJ, Pardiñas UFJ (1996) Revisión de las especies del género Hyperdidelphys Ameghino, 1904 (Mammalia, Marsupialia, Didelphidae), su significado filogenético, estratigráfico y adaptativo en el Neógeno del Cono Sur Sudamericano. Estudios Geológicos 52:327-359

Goin FJ, Rey P (1997) Sobre las afinidades de Monodelphis Burnett, 1830 (Mammalia: Marsupialia: Didelphidae: Marmosinae). Neotropica 43:93-98

Goin FJ, Sánchez-Villagra MR, Abello A, Kay RF (2007b) A new generalized paucituberculatan marsupial from the Oligocene of Bolivia and the origin of 'shrew-like' opossums. Palaeontology 50:1267-1276

Goin FJ, Tejedor MF, Abello MA, Martin GM (2010b) Un nuevo microbiotérido (Mammalia, Marsupialia, Microbiotheria) de la Formación Pinturas (Mioceno temprano) de la provincia de Santa Cruz. Ameghiniana 47:117-122

Goin FJ, Woodburne MO, Zimicz AN, Martin GM, Chornogubsky L (2016) A Brief History of South American Metatherians: Evolutionary Contexts and Intercontinental Dispersals. Springer, Dordrecht

Goin FJ, Zimicz AN, Forasiepi AM, Chornogubsky LC, Abello MA (in press) The rise and fall of South American metatherians: contexts, adaptations, radiations, and extinctions. In: Rosenberger AL, Tejedor MF (eds) Origins and Evolution of Cenozoic South American Mammals. Springer, New York

Gruber KF, Voss RS, Jansa SA (2007) Base-compositional heterogeneity in the RAG1 locus among didelphid marsupials: implications for phylogenetic inference and the evolution of GC content. Syst Biol 56:83-96

Hansen J, Sato M, Russell G, Kharecha P (2013) Climate sensitivity, sea level and atmospheric carbon dioxide. Philos Trans A Math Phys Eng Sci 371:20120294. https://doi.org/10.1098/rsta.2012.0294

Harrison LB, Larsson HCE (2015) Among-character rate variation distributions in phylogenetic analysis of discrete morphological characters. Syst Biol 64:307-324

Ho SY, Phillips MJ (2009) Accounting for calibration uncertainty in phylogenetic estimation of evolutionary divergence times. Syst Biol 58:367-380. https://doi.org/10.1093/sysbio/syp035

Hunt RM Jr (1991) Evolution of the aeluroid Camivora: viverrid affinities of the Miocene carnivoran Herpestides. Am Mus Novit 3023:1-34

Inoue J, Donoghue PCJ, Yang Z (2010) The impact of the representation of fossil calibrations on Bayesian estimation of species divergence times. Syst Biol 59:74-89

Isla F, Taglioretti M, Dondas A (2015) Revisión y nuevos aportes sobre la estratigrafía y sedimentología de los acantilados entre Mar de Cobo y Miramar, provincia de Buenos Aires. Rev Asoc Geol Argent 72: 235-250

Jansa SA, Barker FK, Voss RS (2014) The early diversification history of didelphid marsupials: a window into South America's "splendid isolation." Evolution 68:684-695. https://doi.org/10.1111/Evo.12290

Jones FW (1949) The study of a generalized marsupial (Dasycercus cristicauda Krefft). Trans Zool Soc Lond 26:311-501

Jones ME, Oakwood M, Belcher CA, Morris K, Murray AJ, Woolley PA, Firestone KB, Johnson B, Burnett S (2003) Carnivore concerns: problems, issues and solutions for conserving Australasia's marsupial carnivores. In: Jones M, Dickman C, Archer M (eds) Predators with Pouches: the Biology of Carnivorous Marsupials. CSIRO (Commonwealth Scientific and Industrial Research Organization), Collingwood, pp 422-434
Kass RE, Raftery AE (1995) Bayes factors. J Am Stat Assoc 90:773-795

Kealy S, Beck R (2017) Total evidence phylogeny and evolutionary timescale for Australian faunivorous marsupials (Dasyuromorphia). BMC Evol Biol 17:240. https://doi.org/10. 1186/s12862-017-1090-0

King B, Qiao T, Lee MSY, Zhu M, Long JA (2017) Bayesian morphological clock methods resurrect placoderm monophyly and reveal rapid early evolution in jawed vertebrates. Syst Biol 66:499-516. https://doi.org/10.1093/sysbio/syw107

Kraglievich JL (1952) El perfil geológico de Chapadmalal y Miramar, Provincia de Buenos Aires. Revista Museo Municipal de Ciencias Naturales y Tradicional Mar del Plata 1:8-37

Ladevèze S, Asher RJ, Sánchez-Villagra MR (2008) Petrosal anatomy in the fossil mammal Necrolestes: evidence for metatherian affinities and comparisons with the extant marsupial mole. J Anat 213:686-697

Landis MJ, Schraiber JG, Liang MS (2013) Phylogenetic analysis using Lévy processes: finding jumps in the evolution of continuous traits. Syst Biol 62:193-204. https://doi.org/10.1093/sysbio/sys086

Lanfear R, Frandsen PB, Wright AM, Senfeld T, Calcott B (2017) Partitionfinder 2: new methods for selecting partitioned models of evolution for molecular and morphological phylogenetic analyses. Mol Biol Evol 34:772-773. https://doi.org/10.1093/molbev/ msw260

Lee MSY, Yates AM (2018) Tip-dating and homoplasy: reconciling the shallow molecular divergences of modern gharials with their long fossil record. Proc R Soc B: Biol Sci 285:20181071. https://doi.org/ 10.1098/rspb.2018.1071

Lepage T, Bryant D, Philippe H, Lartillot N (2007) A general comparison of relaxed molecular clock models. Mol Biol Evol 24:2669-2680. https://doi.org/10.1093/molbev/msm193

Lewis PO (2001) A likelihood approach to estimating phylogeny from discrete morphological character data. Syst Biol 50:913-925

Lopatin A (2003) A new genus of the Erinaceidae (Insectivora, Mammalia) from the Oligocene of Mongolia. Paleontol J 37:94-104

López-Aguirre C, Archer M, Hand SJ, Laffan SW, Smith A (2017) Extinction of South American sparassodontans (Metatheria): environmental fluctuations or complex ecological processes? Palaeontology 60:91-115. https://doi.org/10.1111/pala.12272

Louys J, Aplin KP, Beck RMD, Archer M (2009) Cranial anatomy of Oligo-Miocene koalas (Diprotodontia: Phascolarctidae): stages in the evolution of an extreme leaf-eating specialization. J Vertebr Paleontol 29:981-992

MacPhee RDE (1981) Auditory regions of primates and eutherian insectivores: morphology, ontogeny, and character analysis. Contrib Primatol 18:1-282

Macrini TE (2012) Comparative morphology of the internal nasal skeleton of adult marsupials based on X-ray computed tomography. Bull Am Mus Nat Hist 365:1-91

Madden RH, Guerrero J, Kay RF, Flynn JJ, Swisher III CC, Walton AH (1997) The Laventan Stage and Age. In: Kay RF, Madden RH, Cifelli RL, Flynn JJ (eds) Vertebrate Paleontology in the Neotropics: The Miocene Fauna of La Venta, Colombia. Smithsonian Institution Press, Washington, pp 355-381

Maga AM, Beck RMD (2017) Skeleton of an unusual, cat-sized marsupial relative (Metatheria: Marsupialiformes) from the middle Eocene (Lutetian: 44-43 million years ago) of Turkey. PLoS One 12: e0181712. https://doi.org/10.1371/journal.pone.0181712

Marshall CR (2017) Five palaeobiological laws needed to understand the evolution of the living biota. Nature Ecology \& Evolution 1:0165. https://doi.org/10.1038/s41559-017-0165

Marshall LG (1976) New didelphine marsupials from the La Venta fauna (Miocene) of Colombia, South America. J Paleontol 50:402-418

Marshall LG (1977a) Cladistic analysis of borhyaenoid, dasyuroid, didelphoid, and thylacinid (Marsupialia : Mammalia) affinity. Syst Zool 26:410-425 
Marshall LG (1977b) Evolution of the carnivorous adaptive zone in South America. In: Hecht MK, Goodoy PC, Hecht BM (eds) Major Patterns in Vertebrate Evolution. Plenum Press, New York, pp 709-721

Marshall LG (1977c) First Pliocene record of the water opossum, Chironectes minimus (Didelphidae, Marsupialia). J Mammal 58: 434-436. https://doi.org/10.2307/1379349

Marshall LG (1978) Evolution of the Borhyaenidae, extinct South American predaceous marsupials. Univ Calif Publ Geol Sci 117: $1-89$

Marshall LG (1990) Fossil Marsupialia from the type Friasian land mammal age (Miocene), Alto Rio Cisnes, Aisen, Chile. Rev Geol Chile 17:19-55

Marshall LG, Case JA, Woodburne MO (1990) Phylogenetic relationships of the families of marsupials. Curr Mammal 2:433-505

Mason MJ (2016a) Structure and function of the mammalian middle ear. I: large middle ears in small desert mammals. J Anat 228:284-299. https://doi.org/10.1111/joa.12313

Mason MJ (2016b) Structure and function of the mammalian middle ear. II: inferring function from structure. J Anat 228:300-312. https:// doi.org/10.1111/joa.12316

Matzke NJ, Irmis RB (2018) Including autapomorphies is important for paleontological tip-dating with clocklike data, but not with non-clock data. PeerJ 6:e4553. https://doi.org/10.7717/ peerj. 4553

Matzke NJ, Wright A (2016) Inferring node dates from tip dates in fossil Canidae: the importance of tree priors. Biol Lett 12:20160328. https://doi.org/10.1098/rsbl.2016.0328

McKenna MC, Bell SK (1997) Classification of Mammals Above the Species Level. Columbia University Press, New York

Meredith RW, Janecka JE, Gatesy J, Ryder OA, Fisher CA, Teeling EC, Goodbla A, Eizirik E, Simao TL, Stadler T, Rabosky DL, Honeycutt RL, Flynn JJ, Ingram CM, Steiner C, Williams TL, Robinson TJ, Burk-Herrick A, Westerman M, Ayoub NA, Springer MS, Murphy WJ (2011) Impacts of the Cretaceous Terrestrial Revolution and KPg extinction on mammal diversification. Science 334:521-524. https://doi.org/ $10.1126 /$ science. 1211028

Meredith RW, Westerman M, Case JA, Springer MS (2008) A phylogeny and timescale for marsupial evolution based on sequences for five nuclear genes. J Mammal Evol 15:1-36

Mitchell KJ Pratt RC, Watson LN, Gibb GC, Llamas B, Kasper M, Edson J, Hopwood B, Male D, Armstrong KN, Meyer M, Hofreiter M, Austin J, Donnellan SC, Lee MS, Phillips MJ, Cooper A (2014) Molecular phylogeny, biogeography, and habitat preference evolution of marsupials. Mol Biol Evol 31:2322-2330. https://doi.org/10.1093/molbev/ msu176

Mitchell JS, Etienne RS, Rabosky DL (2018) Inferring diversification rate variation from phylogenies with fossils. Syst Biol 68:1-18. https://doi.org/10.1093/sysbio/syy035

Muirhead J, Filan S (1995) Yarala burchfieldi (Peramelemorphia) from Oligo-Miocene deposits of Riversleigh, northwestern Queensland. J Paleontol 69:127-134

Muirhead J, Wroe S (1998) A new genus and species, Badjcinus turnbulli (Thylacinidae: Marsupialia), from the late Oligocene of Riversleigh, northern Australia, and an investigation of thylacinid phylogeny. J Vertebr Paleontol 18:612-626

Muizon C de (1999) Marsupial skulls from the Deseadan (late Oligocene) of Bolivia and phylogenetic analysis of the Borhyaenoidea (Marsupialia, Mammalia). Geobios 32:483-509

Muizon, C de (1998) Mayulestes ferox, a borhyaenoid (Metatheria, Mammalia) from the early Palaeocene of Bolivia: phylogenetic and palaeobiologic implications. Geodiversitas 20:19-142
Muizon C de, Lange-Badré B (1997) Carnivorous dental adaptations in tribosphenic mammals and phylogenetic reconstruction. Lethaia 30: 353-366

Nesslinger CL (1956) Ossification centers and skeletal development in the postnatal Virginia opossum. J Mammal 37:382-394

Nylander JAA, Ronquist F, Huelsenbeck JP, Nieves-Aldrey JL (2004) Bayesian phylogenetic analysis of combined data. Syst Biol 53: 47-67

O'Reilly JE, Donoghue PC (2016) Tips and nodes are complementary not competing approaches to the calibration of molecular clocks. Biol Lett 12:20150975. https://doi.org/10. 1098/rsbl.2015.0975

O'Reilly JE, dos Reis M, Donoghue PC (2015) Dating tips for divergence-time estimation. Trends Genet 31:637-650. https://doi. org/10.1016/j.tig.2015.08.001

Ortiz PE, García López DA, Babot MJ, Pardiñas UFJ, Alonso Muruaga PJ, Jayat JP (2012) Exceptional late Pliocene microvertebrate diversity in northwestern Argentina reveals a marked small mammal turnover Palaeogeogr Palaeoclimatol Palaeoecol 361-362:21-37. https://doi.org/10. 1016/j.palaeo.2012.07.012

Ortiz Jaureguizar E (1998) Palaeoecología y evolución de la fauna de mamiferos de América del Sur durante la 'edad de las planicies australes' (Mioceno superior-Plioceno superior). Estudios Geologicos 54:161-169

Ortiz Jaureguizar E (2001) Cambios en la diversidad de los mamíferos Sudamericanos durante el lapso Mioceno Superior- Holoceno: el caso pampeano. In: Meléndez G, Herrera Z, Delvene G, Azanza B (eds) Los Fósiles y la Paleogeografía. Publicaciones del SEPAZ, Universidad de Zaragoza, Zaragoza, pp 397-403

Ortiz Jaureguizar E, Prado JL, Alberdi MT (1995) Análisis de las comunidades de mamíferos continentales del Plio-Pleistoceno de la región pampeana y su comparación con las del área del Mediterráneo occidental. In: Alberdi MT, Leone G, Tonni EP (eds) Evolución Biológica y Climática de la Región Pampeana Durante los Últimos Cinco Millones de Años. Consejo Superior de Investigaciones Científicas, Madrid, pp 383-406

Ortiz-Jaureguizar E, Cladera GA (2006) Paleoenvironmental evolution of southern South America during the Cenozoic. J Arid Environ 66: 498-532

Palazzesi L, Barreda V (2012) Fossil pollen records reveal a late rise of open-habitat ecosystems in Patagonia. Nature Comm 3:1294. https://doi.org/10.1038/ncomms2299

Parins-Fukuchi C, Brown JW (2017) What drives results in Bayesian morphological clock analyses? bioRxiv preprint 219048: https:// doi.org/10.1101/219048

Pascual R, Bondesio P (1982) Un roedor Cardiatheriinae (Hydrochoeridae) de la Edad Huayqueriense (Mioceno tardío) de La Pampa. Sumario de los ambientes terrestres en la Argentina durante el Mioceno. Ameghiniana 19:19-36

Pascual R, Ortiz-Jaureguizar E, Prado JL (1996) Land mammals: paradigm of Cenozoic South American geobiotic evolution Müncher Geowissenschaftliche Abhandlungen Reihe A: Geologie und Paläontologie 30:265-319

Patterson B, Pascual R (1968) The fossil mammal fauna of South America. Q Rev Biol 43:409-451

Pavan SE, Voss RS (2016) A revised subgeneric classification of shorttailed opossums (Didelphidae: Monodelphis). Am Mus Novitates 3868:1-44

Pérez LM (2013) Nuevo aporte al conocimiento de la edad de la Formación Paraná,. Mioceno de la provincia de Entre Ríos, Argentina. In: Brandoni D, Noriega JI (eds) El Neógeno de la Mesopotamia Argentina. Asociación Paleontológica Argentina, 
Publicación Especial. Asociación Paleontológica Argentina, Buenos Aires, pp 7-12

Phillips MJ, Fruciano C (2018) The soft explosive model of placental mammal evolution. BMC Evol Biol 18:104. https://doi.org/10. 1186/s12862-018-1218-x

Pine RH, Dalby PL, Matson JO (1985) Ecology, postnatal development, morphometrics, and taxonomic status of the short-tailed opossum, Monodelphis dimidiata, an apparently semelparous annual marsupial. Ann Carnegie Mus 54: 195-231

Prevosti FJ, Forasiepi AM (2018) Evolution of South American Mammalian Predators During the Cenozoic: Paleobiogeographic and Paleoenvironmental Contingencies. Springer International Publishing, Cham

Prevosti FJ, Forasiepi AM, Ercoli MD, Turazzini GF (2012) Paleoecology of the mammalian carnivores (Metatheria, Sparassodonta) of the Santa Cruz formation (late early Miocene). In: Vizcaíno SF, Kay RF, Bargo MS (eds) Early Miocene Paleobiology in Patagonia: High-Latitude Paleocommunities of the Santa Cruz Formation. Cambridge University Press, Cambridge, pp 173-193

Prevosti FJ, Forasiepi A, Zimicz N (2013) The evolution of the Cenozoic terrestrial mammalian predator guild in South America: competition or replacement? J Mammal Evol 20:3-21

Prevosti FJ, Pardiñas UFJ (2009) Comment on "The oldest South American Cricetidae (Rodentia) and Mustelidae (Carnivora): late Miocene faunal turnover in central Argentina and the Great American Biotic Interchange" by D.H. Verzi and C.I. Montalvo [Palaeogeography, Palaeoclimatology, Palaeoecology 267 (2008) 284-291]. Palaeogeogr Palaeoclimatol Palaeoecol 280:543-547. https://doi.org/10. 1016/j.palaeo.2009.05.021

Rabosky DL (2010) Extinction rates should not be estimated from molecular phylogenies. Evolution 64:1816-1824. https://doi.org/10. $1111 / \mathrm{j} .1558-5646.2009 .00926 . x$

Rabosky DL (2016) Challenges in the estimation of extinction from molecular phylogenies: A response to Beaulieu and O'Meara. Evolution 70:218-228. https://doi.org/10.1111/evo.12820

Rambaut A, Suchard MA, Xie D, Drummond AJ (2014) Tracer v1.6

Ramirez SR, Roubik DW, Skov C, Pierce NE (2010) Phylogeny, diversification patterns and historical biogeography of euglossine orchid bees (Hymenoptera: Apidae). Biol J Linn Soc 100:552-572. https:// doi.org/10.1111/j.1095-8312.2010.01440.x

Reig OA (1955) Un nuevo género y especie de cenolestinos del Plioceno de la provincia de Buenos Aires (República Argentina). Rev Asoc Geol Argent 10:60-71

Reig OA (1957a) Nota previa sobre los marsupiales de la Formación Chasicó. Ameghiniana 1:27-31

Reig OA (1957b) Sobre la posición sistemática de "Zygolestes paranensis" Amegh. y de "Zygolestes entrerrianus" Amegh., con una reconsideración de la edad y correlación del "Mesopotamiense." Holmbergia 5:209-226

Reig OA (1958a) Comunicación preliminar sobre nuevas especies del género Thylatheridium Reig (Mammalia, Didelphidae). Neotropica 4:89-95

Reig OA (1958b) Notas para una actualizacion del conocimiento de la fauna de la formacion Chapadmalal. II. Amphibia, Reptilia, Aves, Mammalia (Marsupialia: Didelphidae, Borhyaenidae). Acta Geol Lilloana 2:255-283

Reig OA, Kirsch JAW, Marshall LG (1987) Systematic relationships of the living and Neocenozoic American "opossum-like" marsupials (suborder Didelphimorphia), with comments on the classification of these and the Cretaceous and Paleogene New World and European metatherians. In: Archer M (ed) Possums and Opossums: Studies in Evolution. Surrey Beatty and Sons and the Royal Zoological Society of New South Wales, Sydney, pp 1-89
Reig OA, Simpson GG (1972) Sparassocynus (Marsupialia, Didelphidae), a peculiar mammal from the late Cenozoic of Argentina. J Zool 167:511-539

Ronquist F, Klopfstein S, Vilhelmsen L, Schulmeister S, Murray DL, Rasnitsyn AP (2012a) A total-evidence approach to dating with fossils, applied to the early radiation of the Hymenoptera. Syst Biol 61:973-999. https://doi.org/10.1093/sysbio/sys058

Ronquist F, Teslenko M, van der Mark P, Ayres DL, Darling A, Hohna S, Larget B, Liu L, Suchard MA, Huelsenbeck JP (2012b) MrBayes 3.2: efficient Bayesian phylogenetic inference and model choice across a large model space. Syst Biol 61:539-542. https://doi.org/ 10.1093/sysbio/sys029

Rose RK, Pemberton DA, Mooney NJ, Jones ME (2017) Sarcophilus harrisii (Dasyuromorphia: Dasyuridae). Mammal Species 49:117. https://doi.org/10.1093/mspecies/sex001

Sánchez-Villagra MR, Forasiepi AM (2017) On the development of the chondrocranium and the histological anatomy of the head in perinatal stages of marsupial mammals. Zool Lett 3:1. https://doi.org/10. 1186/s40851-017-0062-y

Sánchez-Villagra MR, Wible JR (2002) Patterns of evolutionary transformation in the petrosal bone and some basicranial features in marsupial mammals, with special reference to didelphids. J Zool Syst Evol Res 40:26-45

Schultz PH, Zarate M, Hames W, Camilion C, King J (1998) A 3.3-Ma impact in Argentina and possible consequences. Science 282:2061-2063

Segall W (1943) The auditory region of the arctoid carnivores. Zool Ser Field Mus Nat Hist 29:33-59

Silvestro D, Antonelli A, Salamin N, Quental TB (2015) The role of clade competition in the diversification of North American canids. Proc Natl Acad Sci U S A 112:8684-8689. https://doi.org/10.1073/pnas. 1502803112

Simpson GG (1972) Didelphidae from the Chapadmalal Formation in the Museo Municipal de Ciencias Naturales de Mar del Plata. Revista del Museo Municipal de Ciencias Naturales de Mar del Plata 2:1-40

Simpson GG (1974) Notes on Didelphidae (Mammalia, Marsupialia) from the Huayquerian (Pliocene) of Argentina. Am Mus Novitates 2559:1-15

Sinclair WJ (1906) Mammalia of the Santa Cruz Beds (Marsupialia). Reports of the Princeton University Expeditions to Patagonia 4: $333-460$

Solé F, Ladevèze $S$ (2017) Evolution of the hypercarnivorous dentition in mammals (Metatheria, Eutheria) and its bearing on the development of tribosphenic molars. Evol Dev 19:56-68. https://doi.org/10.1111/ ede. 12219

Stamatakis A (2016) The RAxML v8.2.X Manual

Steiner C, Tilak M-k, Douzery EJP, Catzeflis FM (2005) New DNA data from a transthyretin nuclear intron suggest an Oligocene to Miocene diversification of living South America opossums (Marsupialia: Didelphidae). Mol Phylogenet Evol 35:363-379

Strömberg CAE (2011) Evolution of grasses and grassland ecosystems. Annu Rev Earth Planet Sci 39:517-544. https://doi.org/10.1146/ annurev-earth-040809-152402

Strömberg CA, Dunn RE, Madden RH, Kohn MJ, Carlini AA (2013) Decoupling the spread of grasslands from the evolution of grazertype herbivores in South America. Nat Comm 4:1478. https://doi. org/10.1038/ncomms 2508

Thorne JL, Kishino H (2002) Divergence time and evolutionary rate estimation with multilocus data. Syst Biol 51:689-702. https://doi. org/10.1080/10635150290102456

Tribe CJ (1990) Dental age classes in Marmosa incana and other didelphoids. J Mammal 71:566-569

Turner AH, Pritchard AC, Matzke NJ (2017) Empirical and Bayesian approaches to fossil-only divergence times: a study across three 
reptile clades. PLoS One 12:e169885. https://doi.org/10.1371/ journal.pone. 0169885

Tyndale-Biscoe CH, MacKenzie RB (1976) Reproduction in Didelphis marsupialis and D. albiventris in Colombia. J Mammal 57:249-265

van der Klaauw CJ (1931) The auditory bulla in some fossil mammals. Bull Am Mus Nat Hist 62:1-352

van Nievelt AFH, Smith KK (2005) Tooth eruption in monodelphis domestica and its significance for phylogeny and natural history. Journal of Mammalogy 86 (2):333-341

Vilela JF, De Oliveira JA, Russo CAD (2015) The diversification of the genus Monodelphis and the chronology of Didelphidae (Didelphimorphia). Zool J Linn Soc 174:414-427. https://doi.org/ 10.1111/zoj.12240

Villafañe A, Pérez M, Abello A, Bedatou E, Bond M (2008) Nueva localidad fosilífera del Mioceno Medio en el noroeste de la provincia del Chubut. Actas, III Congreso Latinoamericano de Paleontología de Vertebrados, Resumenes, p 265

Villarroel C, Marshall LG (1983) Two new late Tertiary marsupials (Hathlyacyninae and Sparassocyninae) from the Bolivian Altiplano. J Paleontol 57:1061-1066

Vizcaíno SF, Kay RF, Bargo MS (eds) (2012) Early Miocene Paleobiology in Patagonia: High-Latitude Paleocommunities of the Santa Cruz Formation. Cambridge University Press, Cambridge

Voss RS, Diaz-Nieto JF, Jansa SA (2018) A revision of Philander (Marsupialia: Didelphidae), Part 1: P. quica, P. canus, and a new species from Amazonia. Am Mus Novitates 3891:1-70

Voss RS, Gardner AL, Jansa SA (2004) On the relationships of "Marmosa" formosa Shamel, 1930 (Marsupialia : Didelphidae), a phylogenetic puzzle from the Chaco of northern Argentina. Am Mus Novitates:1-18. https://doi.org/10.1206/0003-0082(2004) 442<0001:Otromf $>2.0 . \mathrm{Co} ; 2$

Voss RS, Jansa SA (2003) Phylogenetic studies on didelphid marsupials II. Nonmolecular data and new IRBP sequences: separate and combined analyses of didelphine relationships with denser taxon sampling. Bull Am Mus Nat Hist 276:1-82

Voss RS, Jansa SA (2009) Phylogenetic relationships and classification of didelphid marsupials, an extant radiation of New World metatherian mammals. Bull Am Mus Nat Hist 322:1-177

Waddell PJ (2008) Fit of fossils and mammalian molecular trees: dating inconsistencies revisited. arXiv:08125114

Wible JR (1990) Late Cretaceous marsupial petrosal bones from North America and a cladistic analysis of the petrosal in therian mammals. J Vertebr Paleontol 10:183-205

Wible JR (2003) On the cranial osteology of the short-tailed opossum Monodelphis brevicaudata (Marsupialia, Didelphidae). Ann Carnegie Mus 72:137-202
Williamson TE, Brusatte SL, Wilson GP (2014) The origin and early evolution of metatherian mammals: the Cretaceous record. Zookeys 465:1-76

Wilson BA, Dickman CR, Fletcher TP (2003) Dasyurid dilemmas: problems and solutions for conserving Australia's small carnivorous marsupials. In: Jones M, Dickman C, Archer M (eds) Predators with Pouches: The Biology of Carnivorous Marsupials. CSIRO (Commonwealth Scientific and Industrial Research Organization), Collingwood, pp 407-421

Woodburne MO (2010) The Great American Biotic Interchange: dispersals, tectonics, climate, sea level and holding pens. J Mammal Evol 17:245-264

Wroe S (1996) Muribacinus gadiyuli (Thylacinidae, Marsupialia), a very plesiomorphic thylacinid from the Miocene of Riversleigh, northwestern Queensland, and the problem of paraphyly for the Dasyuridae. J Paleontol 70:1032-1044

Wroe S (1997) A reexamination of proposed morphology-based synapomorphies for the families of Dasyuromorphia (Marsupialia). 1. Dasyuridae. J Mammal Evol 4:19-52

Wroe S (1999) The geologically oldest dasyurid (Marsupialia), from the Miocene Riversleigh, northwestern Queensland. Palaeontology 42: $1-27$

Wroe S, Brammall J, Cooke BN (1998) The skull of Ekaltadeta ima (Marsupialia, Hypsiprymnodontidae?): an analysis of some cranial features within Marsupialia and a re-investigation of propleopine phylogeny; with notes on the inference of carnivory among mammals. J Paleontol 72:738-751

Xie W, Lewis PO, Fan Y, Kuo L, Chen MH (2011) Improving marginal likelihood estimation for Bayesian phylogenetic model selection. Syst Biol 60:150-160. https://doi.org/10.1093/sysbio/syq085

Zárate MA, Fasano JL (1989) The Plio-Pleistocene record of the central eastern Pampas, Buenos Aires Province, Argentina: the Chapadmalal case study. Palaeogeogr Palaeoclimatol Palaeoecol $72: 27-52$

Zarate MA, Schultz PH, Blasi A, Heil C, King J, Hames W (2007) Geology and geochronology of type Chasicoan (late Miocene) mammal-bearing deposits of Buenos Aires (Argentina). J So Am Earth Sci 23:81-90. https://doi.org/10.1016/j.jsames.2006.09.018

Zhang C, Stadler T, Klopfstein S, Heath TA, Ronquist F (2016) Totalevidence dating under the fossilized birth-death process. Syst Biol 65:228-249. https://doi.org/10.1093/sysbio/syv080

Zimicz N (2014) Avoiding competition: the ecological history of late Cenozoic metatherian carnivores in South America. J Mammal Evol 21:383-393. https://doi.org/10.1007/s10914-014-9255-8

Zuckerkandl E, Pauling L (1965) Evolutionary divergence and convergence in proteins. In: Bryson V, Vogel HJ (eds) Evolving Genes and Proteins. Academic Press, New York, pp 97-166 